\title{
Fresh frozen plasma for cardiovascular surgery (Review)
}

Desborough M, Sandu R, Brunskill SJ, Doree C, Trivella M, Montedori A, Abraha I, Stanworth $S$

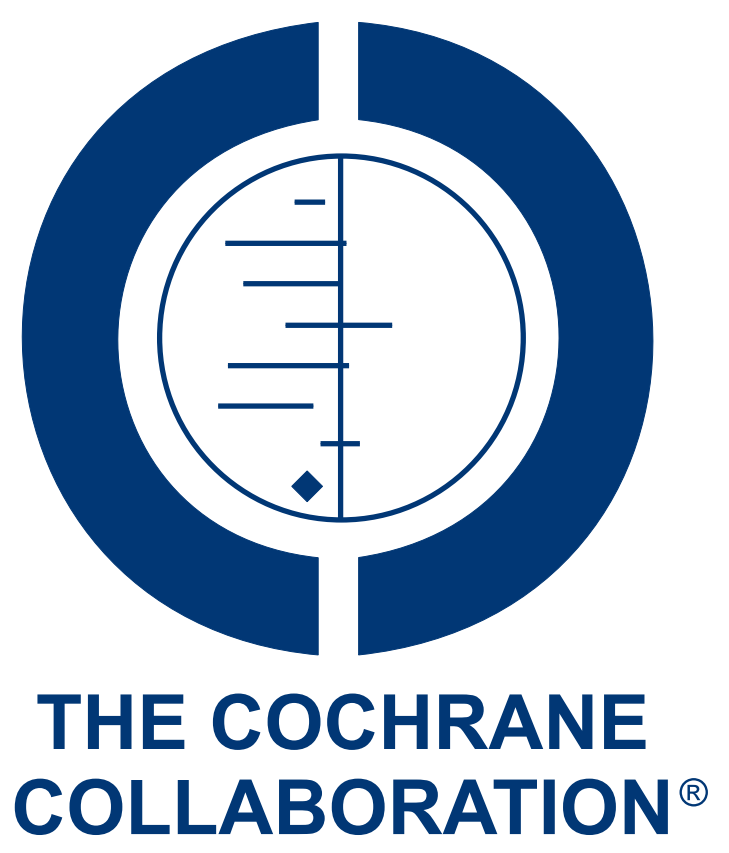

This is a reprint of a Cochrane review, prepared and maintained by The Cochrane Collaboration and published in The Cochrane Library 2015, Issue 7

http://www.thecochranelibrary.com

\section{WILEY}

Fresh frozen plasma for cardiovascular surgery (Review)

Copyright $\odot 2015$ The Cochrane Collaboration. Published by John Wiley \& Sons, Ltd. 
TABLE OF CONTENTS

HEADER

ABSTRACT

PLAIN LANGUAGE SUMMARY

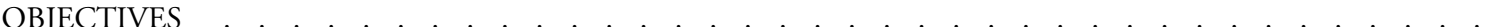

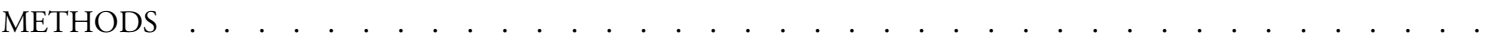

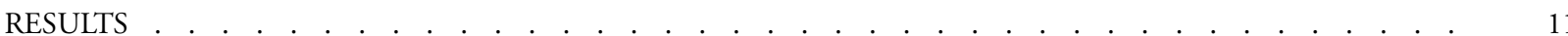

Figure 1. . . . . . . . . . . . . . . . . . . . . . . . . . . . . . . . . 12

Figure 2. . . . . . . . . . . . . . . . . . . . . . . . . . . . . . . . . . . . . . . . . 15

DISCUSSION . . . . . . . . . . . . . . . . . . . . . . . . . . . . . . . . . . . . . .

AUTHORS' CONCLUSIONS . . . . . . . . . . . . . . . . . . . . . . . . . . . . . . . . . . .

ACKNOWLEDGEMENTS . . . . . . . . . . . . . . . . . . . . . . . . . . . . . . . . . 24

REFERENCES . . . . . . . . . . . . . . . . . . . . . . . . . . . . . . . . . . . . . . 24

CHARACTERISTICS OF STUDIES . . . . . . . . . . . . . . . . . . . . . . . . . . . . . . 28

DATA AND ANALYSES . . . . . . . . . . . . . . . . . . . . . . . . . . . . . . . . . . . 66

Analysis 1.1. Comparison 1 Fresh frozen plasma versus no plasma, Outcome 1 Short-term mortality (up to 30 days). 67

Analysis 1.2. Comparison 1 Fresh frozen plasma versus no plasma, Outcome 2 Serious organ damage - myocardial infarction.

Analysis 1.3. Comparison 1 Fresh frozen plasma versus no plasma, Outcome 3 Serious organ damage - renal failure. .

Analysis 1.4. Comparison 1 Fresh frozen plasma versus no plasma, Outcome 4 Bleeding in first 24 hours (adults - ml; neonates and paediatrics $\mathrm{ml} / \mathrm{kg}$ ).

Analysis 1.5. Comparison 1 Fresh frozen plasma versus no plasma, Outcome 5 Transfusion requirements (volume) - red cells (up to 24 hours) (adults - $\mathrm{ml}$; neonates and paediatrics $\mathrm{ml} / \mathrm{kg}$ ).

Analysis 1.6. Comparison 1 Fresh frozen plasma versus no plasma, Outcome 6 Number of patients receiving a red cell transfusion.

Analysis 1.7. Comparison 1 Fresh frozen plasma versus no plasma, Outcome 7 Transfusion requirements - platelets (up to 24 hours) (units).

Analysis 1.8. Comparison 1 Fresh frozen plasma versus no plasma, Outcome 8 Transfusion requirements - cryoprecipitate (up to 24 hours) (units).

Analysis 1.9. Comparison 1 Fresh frozen plasma versus no plasma, Outcome 9 Measurement of prothrombin time within 2 hours of FFP or control infusion.

Analysis 1.10. Comparison 1 Fresh frozen plasma versus no plasma, Outcome 10 Measurement of activated partial thromboplastin time within 2 hours of FFP or control infusion.

Analysis 1.11. Comparison 1 Fresh frozen plasma versus no plasma, Outcome 11 Measurement of fibrinogen concentration

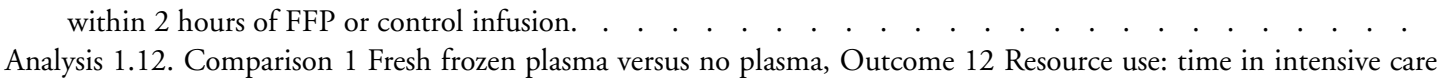
unit.

Analysis 1.13. Comparison 1 Fresh frozen plasma versus no plasma, Outcome 13 Resource use: need for return to theatre.

ADDITIONAL TABLES . . . . . . . . . . . . . . . . . . . . . . . . . . . . . . . . . . 76

APPENDICES . . . . . . . . . . . . . . . . . . . . . . . . . . . . . . . . . . . . . 81

CONTRIBUTIONS OF AUTHORS . . . . . . . . . . . . . . . . . . . . . . . . . . . . . . . . . . . 86

DECLARATIONS OF INTEREST . . . . . . . . . . . . . . . . . . . . . . . . . . . . . . . . . . . . . . 87

SOURCES OF SUPPORT . . . . . . . . . . . . . . . . . . . . . . . . . . . . . . . . . . . . . . . . . . 87

DIFFERENCES BETWEEN PROTOCOL AND REVIEW _. . . . . . . . . . . . . . . . . . . . . . . . 88

Fresh frozen plasma for cardiovascular surgery (Review)

Copyright () 2015 The Cochrane Collaboration. Published by John Wiley \& Sons, Ltd. 


\title{
[Intervention Review] \\ Fresh frozen plasma for cardiovascular surgery
}

\author{
Michael Desborough ${ }^{1}$, Ravinda Sandu ${ }^{2}$, Susan J Brunskill ${ }^{3}$, Carolyn Doree ${ }^{3}$, Marialena Trivella ${ }^{4}$, Alessandro Montedori ${ }^{5}$, Iosief Abraha \\ ${ }^{6}$, Simon Stanworth ${ }^{7}$ \\ ${ }^{1}$ Haematology/Transfusion Medicine, NHS Blood and Transplant, Oxford, UK. ${ }^{2}$ Department of Anaesthesia, The Liverpool Heart \\ and Chest Hospital, Liverpool, UK. ${ }^{3}$ Systematic Review Initiative, NHS Blood and Transplant, Oxford, UK. ${ }^{4}$ Centre for Statistics \\ in Medicine, University of Oxford, Oxford, UK. ${ }^{5}$ Health Planning Service, Regional Health Authority of Umbria, Perugia, Italy. \\ ${ }^{6}$ Servizio Immunotrasfusionale, Azienda Ospedaliera di Perugia, Perugia, Italy. ${ }^{7}$ National Institute for Health Research (NIHR) Oxford \\ Biomedical Research Centre, Oxford University Hospitals and the University of Oxford, Oxford, UK
}

Contact address: Michael Desborough, Haematology/Transfusion Medicine, NHS Blood and Transplant, Oxford, UK. michael.desborough@ouh.nhs.uk.

Editorial group: Cochrane Heart Group.

Publication status and date: New, published in Issue 7, 2015.

Review content assessed as up-to-date: 21 April 2015.

Citation: Desborough M, Sandu R, Brunskill SJ, Doree C, Trivella M, Montedori A, Abraha I, Stanworth S. Fresh frozen plasma for cardiovascular surgery. Cochrane Database of Systematic Reviews 2015, Issue 7. Art. No.: CD007614. DOI: 10.1002/14651858.CD007614.pub2.

Copyright (C) 2015 The Cochrane Collaboration. Published by John Wiley \& Sons, Ltd.

\section{A B S T R A C T}

\section{Background}

Fresh frozen plasma (FFP) is a blood component containing procoagulant factors, which is sometimes used in cardiovascular surgery with the aim of reducing the risk of bleeding. The purpose of this review is to assess the risk of mortality for patients undergoing cardiovascular surgery who receive FFP.

\section{Objectives}

To evaluate the risk to benefit ratio of FFP transfusion in cardiovascular surgery for the treatment of bleeding patients or for prophylaxis against bleeding.

\section{Search methods}

We searched 11 bibliographic databases and four ongoing trials databases including the Cochrane Central Register of Controlled Trials (CENTRAL, Issue 3, 2015), MEDLINE (OvidSP, 1946 to 21 April 2015), EMBASE (OvidSP, 1974 to 21 April 2015), PubMed (epublications only: searched 21 April 2015), ClinicalTrials.gov, World Health Organization (WHO) ICTRP and the ISRCTN Register (searched 21 April 2015). We also searched the references of all identified trials and relevant review articles. We did not limit the searches by language or publication status.

\section{Selection criteria}

We included randomised controlled trials in patients undergoing major cardiac or vascular surgery who were allocated to a FFP group or a comparator (no plasma or an active comparator, either clinical plasma (any type) or a plasma-derived blood product). We included participants of any age (neonates, children and adults). We excluded studies of plasmapheresis and plasma exchange.

\section{Data collection and analysis}

Two authors screened all electronically derived citations and abstracts of papers identified by the review search strategy. Two authors assessed risk of bias in the included studies and extracted data independently. We took care to note whether FFP was used therapeutically or prophylactically within each trial.

Fresh frozen plasma for cardiovascular surgery (Review)

Copyright $\odot 2015$ The Cochrane Collaboration. Published by John Wiley \& Sons, Ltd. 


\section{Main results}

We included 15 trials, with a total of 755 participants for analysis in the review. Fourteen trials compared prophylactic use of FFP against no FFP. One study compared therapeutic use of two types of plasma. The timing of intervention varied, including FFP transfusion at the time of heparin neutralisation and stopping cardiopulmonary bypass (CPB) (seven trials), with CPB priming (four trials), after anaesthesia induction (one trial) and postoperatively (two trials). Twelve trials excluded patients having emergency surgery and nine excluded patients with coagulopathies.

Overall the trials were small, with only four reporting an a priori sample size calculation. No trial was powered to determine changes in mortality as a primary outcome. There was either high risk of bias, or unclear risk, in the majority of trials included in this review.

There was no difference in the number of deaths between the intervention arms in the six trials (with 287 patients) reporting mortality (very low quality evidence). There was also no difference in blood loss in the first 24 hours for neonatal/paediatric patients (four trials with 138 patients; low quality evidence): mean difference (MD) $-1.46 \mathrm{ml} / \mathrm{kg}$ ( $95 \%$ confidence interval (CI) -4.7 to $1.78 \mathrm{ml} / \mathrm{kg}$ ); or adult patients (one trial with 120 patients): MD $-12.00 \mathrm{ml}$ (95\% CI -101.16 to $77.16 \mathrm{ml}$ ).

Transfusion with FFP was inferior to control for preventing patients receiving any red cell transfusion: Peto odds ratio (OR) 2.57 (95\% CI 1.30 to 5.08; moderate quality evidence). There was a difference in prothrombin time within two hours of FFP transfusion in eight trials (with 210 patients; moderate quality evidence) favouring the FFP arm: MD -0.71 seconds ( $95 \%$ CI -1.28 to -0.13 seconds). There was no difference in the risk of returning to theatre for reoperation (eight trials with 398 patients; moderate quality evidence): Peto OR 0.81 (95\% CI 0.26 to 2.57). Only one included study reported adverse events as an outcome and reported no significant adverse events following FFP transfusion.

\section{Authors' conclusions}

This review has found no evidence to support the prophylactic administration of FFP to patients without coagulopathy undergoing elective cardiac surgery. There was insufficient evidence about treatment of patients with coagulopathies or those who are undergoing emergency surgery. There were no reported adverse events attributable to FFP transfusion, although there was a significant increase in the number of patients requiring red cell transfusion who were randomised to FFP. Variability in outcome reporting between trials precluded meta-analysis for many outcomes across all trials, and there was evidence of a high risk of bias in most of the studies. Further adequately powered studies of FFP, or comparable pro-haemostatic agents, are required to assess whether larger reductions in prothrombin time translate into clinical benefits. Overall the evidence from randomised controlled trials for the safety and efficacy of prophylactic transfusion of FFP for cardiac surgery is insufficient.

\section{PLAIN LANGUAGE SUMMARY}

\section{Fresh frozen plasma for patients undergoing surgery on the heart or blood vessels}

Fresh frozen plasma is obtained from whole blood from blood donors. It contains a number of factors that help blood to clot. The risk of bleeding in open heart surgery or surgery on the main blood vessels in the body is high. Fresh frozen plasma is sometimes administered to these patients to reduce bleeding. It can be administered prophylactically (to prevent bleeding) or therapeutically (to treat bleeding). However, there are risks of side effects from fresh frozen plasma, such as severe allergic reactions or breathing problems.

We searched scientific sources to identify eligible trials and found 15 studies with 755 patients. The evidence is up to date to April 2015 . Fourteen studies compared prophylactic FFP against no FFP and one study compared two types of FFP, both used therapeutically. No studies reported on all outcomes. There was either high risk of bias, or unclear risk, in the majority of trials included in this review.

Our primary outcome was death within 30 days after surgery. Six trials (with 287 patients) looked at this outcome and found no clear difference in mortality between the treatment arms but the quality of the evidence was very low. There was also no difference in the amount of blood lost in the first 24 hours following surgery (measured in five trials; low quality evidence), or the risk of returning to theatre for a reoperation (measured in eight trials; moderate quality evidence). Patients who had FFP received significantly more red blood cells, suggesting that FFP may not be effective in this setting (moderate quality evidence). Measurement of a blood test used to assess blood clotting (prothrombin time) was reported in eight trials and showed that clotting was improved by the use of prophylactic FFP (moderate quality evidence). However, the difference was too small to make a difference in clinical practice. Only one included study reported adverse events as an outcome and reported no adverse events due to FFP transfusion.

Fresh frozen plasma for cardiovascular surgery (Review)

Copyright @ 2015 The Cochrane Collaboration. Published by John Wiley \& Sons, Ltd. 
The review found no evidence for the efficacy of FFP for the prevention of bleeding in heart surgery and it found some evidence of an increased overall need for red cell transfusion in those treated with FFP. There were no reported adverse events due to FFP transfusion. Overall the evidence for the safety and efficacy of prophylactic FFP for cardiac surgery is insufficient. The trials focused on prevention of bleeding and did not address prevention of bleeding for patients with abnormal blood clotting or for the treatment of bleeding patients. 


\section{SUMMARY OF FINDINGS FOR THE MAIN COMPARISON [Explanation]}

\section{Fresh frozen plasma compared to no plasma for cardiovascular surgery}

Patient or population: Neonates, children and adults undergoing cardiovascular surgery

Settings: Inpatients

Intervention: Fresh frozen plasma

Comparison: No plasma

\begin{tabular}{|c|c|c|c|c|c|c|}
\hline \multirow[t]{3}{*}{ Outcomes } & \multicolumn{2}{|c|}{ Illustrative comparative risks* (95\% CI) } & \multirow{3}{*}{$\begin{array}{l}\text { Relative effect } \\
(95 \% \mathrm{Cl})\end{array}$} & \multirow{3}{*}{$\begin{array}{l}\text { No of participants } \\
\text { (studies) }\end{array}$} & \multirow{3}{*}{$\begin{array}{l}\text { Quality of the evidence } \\
\text { (GRADE) }\end{array}$} & \multirow[t]{3}{*}{ Comments } \\
\hline & Assumed risk & Corresponding risk & & & & \\
\hline & No plasma & Fresh frozen plasma & & & & \\
\hline $\begin{array}{l}\text { Short-term mortality (up } \\
\text { to } 30 \text { days) }\end{array}$ & See comments & & - & $\begin{array}{l}287 \\
\text { (6 RCTs) }\end{array}$ & $\begin{array}{l}\oplus \bigcirc \bigcirc \bigcirc \\
\text { very low } 1,2\end{array}$ & $\begin{array}{l}2 \text { deaths in total, one each } \\
\text { among patients treated } \\
\text { with FFP and control }\end{array}$ \\
\hline $\begin{array}{l}\text { Blood loss in first } 24 \\
\text { hours (neonates and pae- } \\
\text { diatric cases) }\end{array}$ & $\begin{array}{l}\text { The mean blood loss } \\
\text { in the first } 24 \text { hours } \\
\text { (neonates and paediatric } \\
\text { cases) was } 26.7 \mathrm{ml} / \mathrm{kg}\end{array}$ & $\begin{array}{l}\text { The mean blood loss } \\
\text { in the first } 24 \text { hours } \\
\text { (neonates and paediatric } \\
\text { cases) in the interven- } \\
\text { tion group was } 1.46 \mathrm{ml} / \\
\mathrm{kg} \text { lower ( } 4.7 \text { lower to } 1 . \\
78 \text { more) }\end{array}$ & - & $\begin{array}{l}138 \\
\text { (4 RCTs) }\end{array}$ & $\begin{array}{l}\oplus \oplus \bigcirc \bigcirc \\
\text { low } 3\end{array}$ & $\begin{array}{l}\text { Pooled analy- } \\
\text { sis of neonates and pae- } \\
\text { diatric cases only. Single } \\
\text { adult study: mean differ- } \\
\text { ence }-12.00 \mathrm{ml}(95 \% \mathrm{Cl} \text { - } \\
101.16 \text { to } 77.16 \mathrm{ml}, 120 \\
\text { patients) }\end{array}$ \\
\hline $\begin{array}{l}\text { Red cell transfusion re- } \\
\text { quirement in first } 24 \\
\text { hours (neonates and pae- } \\
\text { diatric cases) }\end{array}$ & $\begin{array}{l}\text { The mean red cell trans- } \\
\text { fusion requirement in the } \\
\text { first } 24 \text { hours (neonates } \\
\text { and paediatric cases) } \\
\text { was } 7.9 \mathrm{ml} / \mathrm{kg}\end{array}$ & $\begin{array}{l}\text { The mean red cell trans- } \\
\text { fusion requirement in the } \\
\text { first } 24 \text { hours (neonates } \\
\text { and paediatric cases) in } \\
\text { the intervention group } \\
\text { was } 0.4 \mathrm{ml} / \mathrm{kg} \text { more (2. } \\
99 \text { less to } 3.79 \text { more) }\end{array}$ & - & $\begin{array}{l}110 \\
\text { (3 RCTs) }\end{array}$ & $\begin{array}{l}\oplus \oplus \bigcirc \bigcirc \\
\text { low } 3\end{array}$ & $\begin{array}{l}\text { Pooled analy- } \\
\text { sis of neonates and pae- } \\
\text { diatric cases only. Single } \\
\text { adult study: mean differ- } \\
\text { ence } 150.00 \mathrm{ml}(95 \% \mathrm{Cl} \\
-128.63 \text { to } 428.63 \mathrm{ml}, 32 \\
\text { patients) }\end{array}$ \\
\hline
\end{tabular}




\begin{tabular}{|c|c|c|c|c|c|c|}
\hline \multirow{4}{*}{$\begin{array}{l}\text { Number of patients re- } \\
\text { ceiving a red cell transfu- } \\
\text { sion }\end{array}$} & \multicolumn{2}{|l|}{ Study population } & \multirow{4}{*}{$\begin{array}{l}\text { OR } 2.57 \\
-(1.30 \text { to } 5.08)\end{array}$} & \multirow{4}{*}{$\begin{array}{l}222 \\
\text { (4 RCTs) }\end{array}$} & \multirow{4}{*}{$\begin{array}{l}\oplus \oplus \oplus \bigcirc \\
\text { moderate } 3,4\end{array}$} & - \\
\hline & 236 per 1000 & $\begin{array}{l}443 \text { per } 1000 \\
\text { (287 to } 611)\end{array}$ & & & & \\
\hline & \multicolumn{2}{|l|}{ Moderate } & & & & \\
\hline & 558 per 1000 & $\begin{array}{l}765 \text { per } 1000 \\
(622 \text { to } 865)\end{array}$ & & & & \\
\hline $\begin{array}{l}\text { Measurement of pro- } \\
\text { thrombin time within } 2 \\
\text { hours of infusion }\end{array}$ & $\begin{array}{l}\text { The mean measure- } \\
\text { ment of prothrombin time } \\
\text { within } 2 \text { hours of infusion } \\
\text { was } 14.38 \text { seconds }\end{array}$ & $\begin{array}{l}\text { The mean measure- } \\
\text { ment of prothrombin time } \\
\text { within } 2 \text { hours of infusion } \\
\text { in the intervention group } \\
\text { was } 0.71 \text { seconds less } \\
\text { (1.28 less to } 0.13 \text { less) }\end{array}$ & - & $\begin{array}{l}210 \\
\text { (5 RCTs) }\end{array}$ & $\begin{array}{l}\oplus \oplus \oplus \bigcirc \\
\text { moderate }{ }^{1}\end{array}$ & - \\
\hline \multirow{4}{*}{$\begin{array}{l}\text { Resource use: need for } \\
\text { return to theatre }\end{array}$} & Study population & & \multirow{4}{*}{$\begin{array}{l}\text { OR } 0.81 \\
-(0.26 \text { to } 2.57)\end{array}$} & \multirow{4}{*}{$\begin{array}{l}398 \\
\text { (7 RCTs) }\end{array}$} & \multirow{4}{*}{$\begin{array}{l}\oplus \oplus \oplus \bigcirc \\
\text { moderate } 1\end{array}$} & \multirow[t]{4}{*}{ - } \\
\hline & 34 per 1000 & $\begin{array}{l}28 \text { per } 1000 \\
\text { (9 to } 83)\end{array}$ & & & & \\
\hline & \multicolumn{2}{|l|}{ Moderate } & & & & \\
\hline & 65 per 1000 & $\begin{array}{l}53 \text { per } 1000 \\
\text { (18 to } 152)\end{array}$ & & & & \\
\hline
\end{tabular}

*The basis for the assumed risk (e.g. the median control group risk across studies) is provided in footnotes. The corresponding risk (and its $95 \%$ confidence interval) is based on the assumed risk in the comparison group and the relative effect of the intervention (and its $95 \% \mathrm{Cl}$ ).

Cl: confidence interval; FFP: fresh frozen plasma; OR: odds ratio; RCT: randomised controlled trial

\section{GRADE Working Group grades of evidence}

High quality: Further research is very unlikely to change our confidence in the estimate of effect.

Moderate quality: Further research is likely to have an important impact on our confidence in the estimate of effect and may change the estimate.

Low quality: Further research is very likely to have an important impact on our confidence in the estimate of effect and is likely to change the estimate.

Very low quality: We are very uncertain about the estimate.

v ${ }^{1}$ Serious risk of bias due to inadequate or unclear sequence generation. 


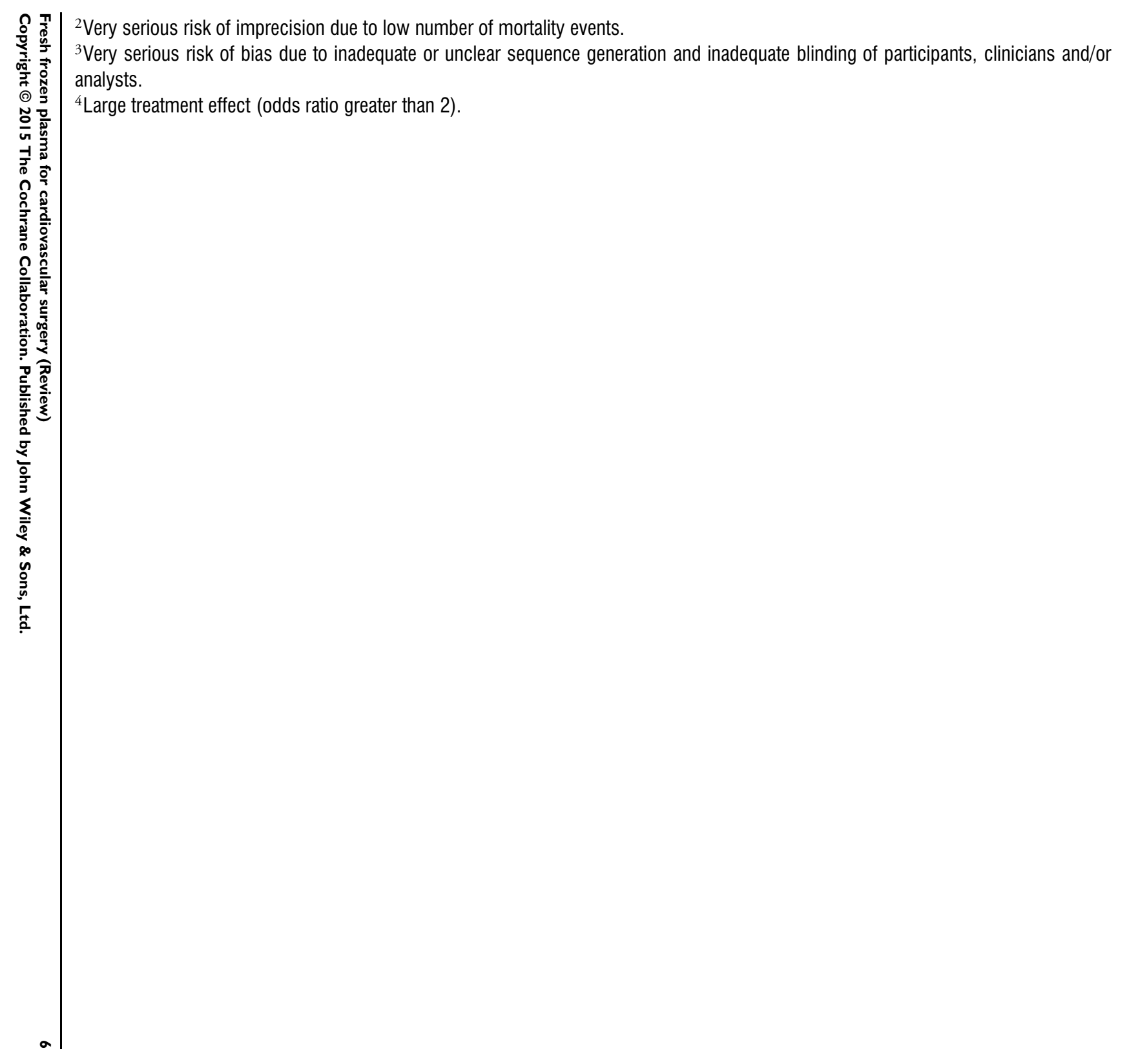




\section{B A C K G R O U N D}

\section{Description of the condition}

Cardiovascular surgery includes many types of major surgery on the heart and major blood vessels, including procedures such as: heart valve replacements, coronary artery bypass grafts, aortic aneurysm repairs and corrections or congenital abnormalities of the heart. Cardiovascular surgery is associated with a significant risk of bleeding, with $8 \%$ of patients losing more than $2 \mathrm{ml} / \mathrm{kg} /$ hour of blood postoperatively (Vuylsteke 2011). A number of features make patients undergoing cardiovascular surgery more likely to bleed (Bevan 1999; Hartmann 2006):

1. These patients may be taking drugs that predispose towards bleeding, such as aspirin or clopidogrel.

2. Patients undergoing major heart surgery will often require a cardiopulmonary bypass (CPB), where a circuit is formed by removing the heart from the circulation by passing a catheter into the aorta and the pulmonary artery while a CPB machine circulates blood round the body and ensures that it is adequately oxygenated. Heparin is used to prevent the CPB circuit from clotting. Heparin is an anticoagulant and can predispose patients to bleeding. When CPB is complete, heparin is neutralised with protamine.

3. Hypothermia and acidosis during the procedure may also contribute towards excess bleeding.

4. Dilution of clotting factors with administration of intravenous fluid; this is a particular problem in the paediatric setting.

5. When acute bleeding develops, clotting factors are consumed, resulting in a coagulopathy and predisposing the patient towards further bleeding.

In some cases these patients will have a clearly defined bleeding risk. They may already be haemorrhaging and, if this is the case, treatments to reduce bleeding would be considered therapeutic. Alternatively they may have abnormal blood results, such as a prolonged prothrombin time, suggesting that clotting factors may be deficient. Lastly, in some cases it may be presumed that a coagulopathy may develop and that prophylactic treatment before this event would reduce the risk of bleeding.

Treatment strategies to reduce bleeding include optimising surgical technique to minimise blood loss; antifibrinolytic agents such as tranexamic acid; careful monitoring and neutralisation of heparin; optimising the management of anticoagulant and antiplatelet drugs; and blood components such as fresh frozen plasma (FFP) (Davidson 2014).

\section{Description of the intervention}

FFP is human plasma that has been obtained from human donation. It contains a large number of proteins including procoagulant factors such as fibrinogen and factors II, V, VII, VIII, IX,
$\mathrm{X}$ and XI. It also contains anticoagulants such as protein C, protein $S$ and antithrombin, along with a large number of proteins such as immunoglobulins, albumin and acute phase proteins. In clinical practice it is often used to treat a presumed coagulopathy in a bleeding patient in order to arrest bleeding, or it is used prophylactically to prevent bleeding (Desborough 2012). The risk to benefit ratio for FFP transfusion may be significantly different when comparing FFP for bleeding patients to FFP used prophylactically.

There are several preparations of FFP. In order to reduce transmission of infectious agents (pathogen inactivation), FFP can be treated with a number of agents including methylene blue; psoralens and ultraviolet light; or solvent and detergent. These preparations are very similar but some procoagulant proteins may be lost during the manufacturing process for pathogen-inactivated FFP (Pamphilon 2000).

FFP is used in a wide range of clinical and surgical specialties in hospital practice. Its use has also grown steadily over the last two decades in many countries (Wallis 2004). There is evidence of variation in usage both within and between countries (Palo 2006). In a comparison of FFP use in five countries, the ratio of FFP units to red blood cell units transfused varied from 1:3.6 in the United States to 1:8.5 in France. The reasons for, and implications of, this variation are not well understood, especially since the case mix may be quite different between countries and institutions, and the available consensus guidelines in this area are frequently based on quite limited evidence.

Guidelines exist for clinical plasma use in many countries but crucial to any recommendations is the need for a clear understanding of the risk of harm (BCSH Guidelines 2004; CMA Guidelines 1997; Lundberg 1994; Roseff 2002; SHOT 2014). Clinical plasma is not without risk and indeed may be amongst the highest risk of all blood components (Khan 2007; MacLennan 2006). Transfusion-related acute lung injury (TRALI) is a potentially life-threatening non-cardiogenic pulmonary oedema associated with plasma-containing components. Ongoing issues of reporting and diagnosis of this condition make accurate estimation of prevalence difficult (Andrzejewski 2005; Vlaar 2013), but many countries have introduced major measures to try to reduce this risk. Other risks include transfusion-transmitted infections and transfusion-associated circulatory overload, which may be a particular issue with larger doses of clinical plasma transfused (for example, in an attempt to completely normalise abnormal coagulation test results) (Narick 2012; Skeate 2007). Allergic reactions to plasma are relatively common, with a frequency of around $1 \%$ to $3 \%$ of all transfusions, and while most are not serious they can involve life-threatening anaphylaxis.

\section{How the intervention might work}

FFP is a source of procoagulant factors, including fibrinogen, and is used for either the treatment or prophylaxis of bleeding 
(Desborough 2012). Many audits indicate that patients undergoing major cardiac and vascular surgery receive a significant proportion of all clinical plasma transfusions. Some studies have reported wide variation in the use of clinical plasma for cardiac surgery and in critical care among centres within the same country (Stanworth 2011).

\section{Why it is important to do this review}

In a search for an earlier systematic review on the use of FFP, the largest numbers of trials were in cardiac surgery (Yang 2012). This previous review was based on a search strategy undertaken over three years ago. As cardiac surgery is amongst the largest users of FFP, it is important to assess the evidence base for its efficacy.

\section{O B J E C T I V E S}

To evaluate the risk to benefit ratio of FFP transfusion in cardiovascular surgery for the treatment of bleeding patients or for prophylaxis against bleeding.

\section{METHODS}

\section{Criteria for considering studies for this review}

\section{Types of studies}

Randomised controlled trials (RCTs), published or unpublished.

\section{Types of participants}

Adult or paediatric patients undergoing major cardiac or vascular surgery.

\section{Types of interventions}

Clinical plasma for transfusion, in various formulations (FFP, FP24, solvent/detergent, etc.) and in various doses, is given primarily for two indications: to prevent bleeding (prophylaxis) or stop bleeding (therapeutic). We included both prophylactic and therapeutic studies. We paid careful attention to the timing of the intervention, for example, whether the plasma infusion occurred pre-, during or post-cardiac bypass.

We also considered trials by reference to the comparator group:

1. Studies of interventions comparing any clinical plasma transfusion with no plasma; where 'no plasma' includes no intervention (placebo); surgical intervention only to correct bleeding; or use of an alternative product (e.g. solutions of colloids and/or crystalloids, recombinant factor VIIa).

2. Studies of interventions comparing clinical plasma (any type) or plasma-derived blood product (for example, prothrombin complex concentrate), including studies comparing different doses and formulations of plasma (e.g. FFP, FP24, solvent-detergent and methylene-blue treated) (Pamphilon 2000; Pelletier 2006), and liquid thawed plasma (stored for up to five days).

We recorded co-interventions such as the use of transfusion algorithms or the use of other transfusion modalities (for example, intraoperative or postoperative cell salvage procedures).

Plasmapheresis and plasma exchange are specialised techniques in which patient plasma is removed and fractionated in an apheresis machine, and replaced by other solutions. These replacement solutions may include (allogeneic) FFP (or another agent such as human albumin solution), and are then re-infused into the patient. The principle aim of this therapy is the removal of a component in blood from the patient, rather than the transfusion of FFP as a source of supplementary pro-coagulant factor. Consequently, we excluded studies of plasmapheresis and plasma exchange from this review.

\section{Types of outcome measures}

\section{Primary outcomes}

- Short-term mortality rate (30 days or in hospital).

\section{Secondary outcomes}

- Major complications: serious organ damage (respiratory failure, myocardial infarction, stroke, renal failure) or haemorrhage (presence or absence of major/unexpected bleeding and, if present, volume of blood loss, when stated).

- Transfusion requirements (for example, red cells, platelets, plasma, cryoprecipitate) or prohaemostatic agents such as tranexamic acid or recombinant factor VIIa.

- Measurement of coagulation factors or tests (by prothrombin time, activated partial thromboplastin time or equivalent).

- Adverse events (transfusion reactions).

- Resource use: for example, length of hospital stay, time in operating theatre or intensive care unit, need for return to theatre/reoperation for management of bleeding.

\section{Search methods for identification of studies}

\section{Electronic searches}


The Systematic Review Initiative's Information Specialist (CD) formulated the search strategies in collaboration with the Cochrane Heart Group. We searched the following databases:

\author{
Bibliographic databases \\ - Cochrane Central Register of Controlled Trials \\ (CENTRAL, Issue 3, 2015). \\ - MEDLINE (OvidSP, 1946 to 21 April 2015). \\ - EMBASE (OvidSP, 1974 to 21 April 2015). \\ - PubMed (e-publications only: searched 21 April 2015). \\ - Transfusion Evidence Library ( \\ www.transfusionevidencelibrary.com) (1950 to 21 April 2015).
}

The databases below were last searched on 26 February 2014:

- CINAHL (NHS Evidence) (1982 to 26 February 2014).

- LILACS (1982 to 26 February 2014).

- IndMed (1985 to 26 February 2014).

- KoreaMed (1997 to 26 February 2014).

- PakMediNet (1995 to 26 February 2014).

- Web of Science: Conference Proceedings Citation IndexScience (CPCI-S) (Thomson Reuters, 1990 to 26 February 2014).

\section{Online databases of ongoing trials}

- ClinicalTrials.gov (clinicaltrials.gov) (searched 21 April 2015).

- ISRCTN Register (www.controlled-trials.com/isrctn/) (searched 21 April 2015).

- World Health Organization (WHO) International Clinical Trials Registry Search Platform (ICTRP) (apps.who.int/ trialsearch/AdvSearch.aspx) (searched 21 April 2015).

- EU Clinical Trials Register (EUDRACT) (searched 21 April 2015).

All search strategies used are listed in Appendix 1. We combined searches in MEDLINE with the Cochrane highly sensitive RCT search filter as detailed in Chapter 6 of the Cochrane Handbook for Systematic Reviews of Interventions (Lefebvre 2011). We combined searches in EMBASE and CINAHL with adaptations of the relevant Scottish Intercollegiate Guidelines Network (SIGN) RCT filters (www.sign.ac.uk/methodology/filters.html). We applied no restrictions on language or publication status.

\section{Searching other resources}

We checked the references of all identified trials, relevant review articles and current treatment guidelines for further literature. These searches were limited to the 'first generation' reference lists.

\section{Data collection and analysis}

\section{Selection of studies}

Two authors (MD and RS) screened all titles and abstracts of papers identified for relevance to the review question. We only excluded studies that were clearly irrelevant at that stage. We assessed all other studies on the basis of their full text for inclusion or exclusion using the criteria indicated above. At this stage, two authors (MD and RS) independently assessed eligibility. We did not formally assess inter-rater reliability. We resolved disagreements by consensus in discussion with a third author (SS). We recorded the numbers of studies assessed, included and excluded. We carefully assessed and clearly indicated any duplicate reporting of studies.

\section{Data extraction and management}

Aside from details relating to risk of bias in included studies (see below), we extracted the following two groups of data:

1. Study characteristics: place of publication, date of publication, population characteristics, setting, detailed nature of intervention, detailed nature of comparator and detailed nature of outcomes. A key purpose of these data was to highlight clinical heterogeneity in included studies independently from an analysis of results. Use of blood components should automatically be considered a 'complex intervention', so considerable care was required in identifying and recording all important aspects of both the intervention and comparator(s).

2. Results of included studies in respect of each of the main outcomes indicated in the review question. We carefully recorded the reasons why an included study did not contribute data on a particular outcome and considered the possibility of selective reporting of results on particular outcomes.

Two authors performed data extraction independently (MD and RS). We extracted data onto study specific data extraction forms. We resolved disagreements by consensus between the authors, but we did not formally assess inter-rater reliability. Once disagreements were resolved, we recorded the consensus data extracted onto a third data extraction form (SB). One author (MD) transcribed this into the systematic review computer software RevMan 5.3 (RevMan 2014). Another author (SB) assessed all data entry for discrepancies.

\section{Assessment of risk of bias in included studies}

Two authors (MD and RS) assessed all included studies for possible risk of bias, using the 'Risk of bias' tool, as described in Chapter 8 of the Cochrane Handbook for Systematic Reviews of Interventions (Higgins 2011a). We resolved disagreements by consensus between the review authors, but we did not formally assess interrater reliability. The assessment included information about the design, conduct and analysis of the trial. We evaluated the follow- 
ing criteria using a three-point scale (low, high or unclear risk of bias).

- Generation of random sequence.

- Concealment of treatment allocation schedule.

- Blinding of clinician (person delivering treatment) to treatment allocation.

- Blinding of participant to treatment allocation.

- Blinding of outcome assessor to treatment allocation.

- The proportion of randomised participants included in the main analysis, noting particularly where more than $20 \%$ are 'lost'. We also took account of differing levels of loss to follow-up affecting the validity of the results for different outcomes to different degrees.

- Equal use of co-interventions in each study arm.

- Balance of baseline prognostic factors.

We recorded in full any problems in respect of the methodological criteria. A narrative summary is presented in a tabular form (and discussed in the text where relevant) within the review. For each included trial we evaluated and graded, as present, absent or unclear, information about the method of allocation, blinding of outcome evaluators and whether all the randomised patients were accounted for in the analysis (intention-to-treat). We used these criteria to assess quality to draw an overall assessment of validity for each trial using three categories: low, unclear or high risk of bias and we presented this in a 'Risk of bias' table as appropriate. We used quality assessment to explore differences in the results of studies as part of any investigations of heterogeneity (see below) or in sensitivity analyses to explore the robustness of summary estimates. We did not use quality assessment as the basis for late exclusion of studies from the review.

In the case of generation of the allocation sequence, examples of randomisation methods falling into each category were as follows.

- Low risk: adequate generation of allocation sequence: random numbers generated by computer, table of random numbers, drawing of lots or envelopes, tossing a coin, shuffling cards, throwing dice.

- High risk: inadequate generation of allocation sequence: case record number, date of birth, day, month or year of admission (Juni 2001).

- Unclear risk: generation of allocation sequence unclear as reported.

In the case of allocation concealment, examples of randomisation methods falling into each category were as follows.

- Low risk: adequate concealment of allocation:

- centralised randomisation (allocation by central office unaware of participant characteristics) or pharmacy-controlled randomisation;

$\circ$ pre-numbered or coded identical containers, which are administered serially to patients;

$\circ$ on-site computer system combined with allocations

kept in a locked unreadable computer that can be accessed only after the characteristics of an enrolled participant have been entered;

- sequentially numbered, sealed, opaque envelopes.

- High risk:

$\circ$ any procedure that was entirely transparent before allocation;

$\circ$ use of case record numbers;

$\circ$ use of dates of birth;

$\circ$ use of days of the week.

- Unclear risk:

○ unclear concealment of allocation;

- no reporting of approach to concealment;

- merely stating that a list or table was used;

$\circ$ only specifying that sealed envelopes were used.

$\circ$ inadequate concealment of allocation.

\section{'Summary of findings' tables}

We interpreted the findings with the GRADE approach ( Langendam 2013) and we used GRADE profiler (GRADEpro 2014) to import data from Review Manager 5.3 (RevMan 2014) to create 'Summary of findings' tables. When assessing the quality of evidence, we downgraded outcomes by one level for serious, or two levels for very serious, limitations. The tables can be used to compare the magnitude of the effect of the FFP transfusion on each outcome examined. We included the following outcomes in the 'Summary of findings' table:

- Short-term mortality (up to 30 days).

- Blood loss in the first 24 hours (neonates and paediatric cases).

- Red cell transfusion requirements in the first 24 hours (neonates and paediatric cases).

- Number of patients receiving a red cell transfusion.

- Measurement of prothrombin time within two hours of infusion.

- Resource use: need for return to theatre.

\section{Measures of treatment effect}

For dichotomous outcomes, we recorded the numbers of outcomes in the treatment and control groups and due to the small number of reported events we used the Peto odds ratio (Peto OR), with a $95 \%$ confidence interval (CI) to report the treatment effect measures across individual studies. For continuous outcomes, we recorded the mean and standard deviations (SD). For continuous outcomes measured using the same scale, the effect measure was the mean difference (MD) with 95\% CIs and, if data necessitated, the standardised mean difference (SMD) for outcomes measured using different scales.

One trial reported some outcome data (prothrombin time and activated partial thromboplastin time) as a mean with standard error of the mean (Consten 1996). We have converted the standard error of the mean data to standard deviations using the formula

Fresh frozen plasma for cardiovascular surgery (Review) 
presented in Chapter 7 of the Cochrane Handbook for Systematic Reviews of Interventions (Higgins 2011b).

As was expected, a number of trials reported the measurement of coagulation factors at multiple time points. We extracted all data, but we made an a priori decision to include in the analyses only those time points that were reported by the majority of studies reporting data for each outcome. The time point used per outcome is reported for each outcome in the Effects of interventions section. We included two trials with three arms in this review (Kyoung 2004; Tølløfsrud 2003). Kyoung 2004 was a three-arm trial comparing FFP to two different concentrations of hydroxyethyl starch (130/0.4 and 200/0.5). In this review, we only used data from the FFP and hydroxyethyl starch 130/0.4 arms because using all three arms could have led to double-counting of data in the FFP arm or underestimated any FFP outcome data. When choosing which of the two comparator arms to use, we chose hydroxyethyl starch $130 / 0.4$ as it is most similar to the comparator arms of the other trials included in this review.

Tølløfsrud 2003 randomised patients to one of two types of FFP (Octaplas and Uniplas). However, data were not reported for a combined Uniplas group because the Uniplas group was split after randomisation into patients with blood group $\mathrm{A}, \mathrm{B}$ or $\mathrm{AB}$; and into those with blood group $\mathrm{O}$. The results for these groups were reported separately. Consequently, the data from this trial are not included in the meta-analysis and are instead reported qualitatively in the Effects of interventions section.

\section{Unit of analysis issues}

We included one cross-over trial, Martinowitz 1990, and no cluster-randomised trials in this review. As it was unclear when crossover had taken place (before or after the effect measurements), we were unable to use any outcome data from this trial in the review. There were no other unit of analysis issues.

\section{Dealing with missing data}

We excluded no trials on the basis of missing data. Where possible we sought missing data from the authors of individual trials. There were some additional data that we would have like to obtain but these were for trials published before 1990, and given the unavailability of any current contact details for any of the listed authors, we were unable to obtain these missing data.

\section{Assessment of heterogeneity}

We assessed the presence of statistical heterogeneity through a combination of visual inspection of the forest plots and the $\mathrm{I}^{2}$ statistic, with a value of $>50 \%$ being considered considerable heterogeneity. If there was substantial heterogeneity $\left(\mathrm{I}^{2}>80 \%\right)$ we did not report the pooled results. We investigated statistical heterogeneity in relation to aspects of the study population, intervention, outcome measurement and study quality, particularly allocation concealment.

\section{Assessment of reporting biases}

We made every effort to identify unpublished studies and although we included 15 trials in this review, as there were no meta-analyses with more than 10 trials we did not perform an assessment of reporting biases.

\section{Data synthesis}

We undertook meta-analysis using Review Manager 5.3 for analysis (RevMan 2014), where there was homogeneity in the intervention, participants and means by which the outcome was measured. We used and reported a random-effects model as most blood components are not totally standardised interventions and it would therefore be a false assumption to claim that they were by using the fixed-effect $\mathrm{ml}$. Where the event numbers are small the Peto odds ratio method is used, and hence for these analyses (as per the methods' pre-requisite) we have reported the Peto odds ratio with a fixed-effect model.

As well as quantitative synthesis, the overall interpretation incorporated insights from qualitative summary. Conclusions were based on patterns of results identified across tabulated results of included studies as well as summary measures. We considered both the direction and magnitude of any effect.

\section{Subgroup analysis and investigation of heterogeneity}

We primarily investigated statistical heterogeneity through subgrouping. Aspects of the study population (neonates and children as compared to adults) and the nature of the comparator arm were the primary considerations and we investigated and reported these where undertaken in the text.

\section{Sensitivity analysis}

We did not perform sensitivity analysis, as few trials reporting our primary outcome of mortality were identified $(n=5)$ and there was little heterogeneity between them.

\section{R E S U L T S}

\section{Description of studies}

\section{Results of the search}

The database searches identified 2150 references (2079 published articles and 71 ongoing studies). After an initial screening of these references, we excluded 460 as duplicates. Two authors (MD, RS) screened the remaining 1690 references according to the criteria defined above, and we excluded 1652 references as either not a 
randomised controlled trial (RCT) or clearly outside the scope of this review (Figure 1). We obtained the full text of the remaining 38 references.

Figure I. Study flow diagram.

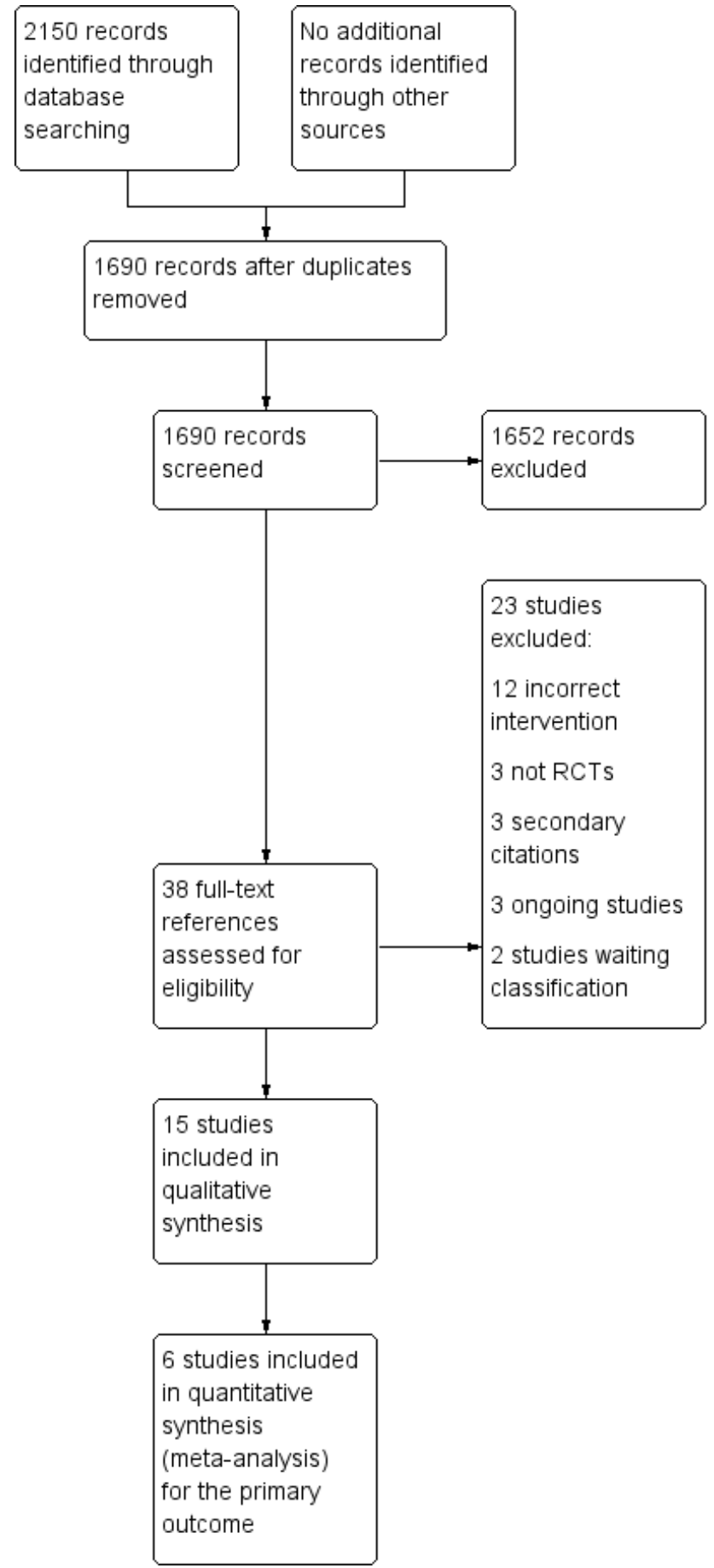


We considered 15 studies eligible for inclusion and excluded 23 trials for not meeting the eligibility criteria of this review. Of these, three references from two trials were identified in a repeat search immediately before publication and these are listed as studies awaiting classification (Miao 2014; Miao 2015). We contacted, by email, the authors of nine of the eligible trials for further information about their trials (Chong Sung 2006; Kanbak 2011; Kasper 2001; Kyoung 2004; Lee 2013; Loeffelbein 2008; McCall 2004; Oliver 2003; Trimble 1964). Three of the authors responded to our enquiries and we incorporated the information and data they provided into this review (Kanbak 2011; McCall 2004; Oliver 2003).

\section{Included studies}

Fifteen trials were eligible for inclusion in this review (see Characteristics of included studies table). We excluded one crossover study (40 patients) from the outcome analysis because the data were uninterpretable due to a major methodological flaw in the study design (Martinowitz 1990). We included data from this study in the 'Risk of bias' assessment.

\section{Design}

The trials were published between 1964 and 2013. All 15 were published as full-text articles, with 14 published in English and one in Korean (Kyoung 2004). Thirteen trials were parallel-group two-arm trials, two were parallel-group three-arm trials (Kyoung 2004; Tølløfsrud 2003), and one trial was a randomised crossover trial (Martinowitz 1990). One of the intervention arms in one of the parallel-group two-arm trials was reported as a threearm trial due to dividing one intervention arm by blood type: this has limited the inclusion of the data from this trial in our review (Tølløfsrud 2003).

\section{Sample sizes}

The trials included 755 patients. The number of patients ranged from 17 (Långström 2008) to 121 (Lee 2013).

\section{Setting}

The trials were conducted in nine countries, with four trials in the United States of America (McCall 2004; Oliver 2003; Snow 1982; Trimble 1964); three in Germany (Loeffelbein 2008; Kasper 2001; Wilhelmi 2001); three in South Korea (Chong Sung 2006; Kyoung 2004; Lee 2013); and one in each in Finland (Långström 2008), Israel (Martinowitz 1990), Norway (Tølløfsrud 2003), Turkey (Kanbak 2011), and the Netherlands (Consten 1996).

\section{Patients}

The patients were adults, children or neonates. Seven trials looked at adults only (Consten 1996; Kanbak 2011; Kasper 2001; Martinowitz 1990; Snow 1982; Tølløfsrud 2003; Wilhelmi 2001), two trials looked at children only (Chong Sung 2006; Kyoung 2004), two trials included neonates only (Långström 2008; McCall 2004), three trials included neonates and children (Lee 2013; Loeffelbein 2008; Oliver 2003), and one trial included adults and children but analysed them separately (Trimble 1964).

\section{Interventions}

\section{Studies of interventions comparing any clinical plasma transfusion with no plasma}

Fourteen trials compared fresh frozen plasma (FFP) with no FFP, although the 'no FFP' comparator arm differed across the trials. Seven trials examined the effects of FFP transfusion at time of heparin neutralisation and stopping cardiopulmonary bypass (CPB) (Chong Sung 2006; Kasper 2001; Kyoung 2004; Martinowitz 1990; Snow 1982; Trimble 1964; Wilhelmi 2001), four trials examined the effects of FFP transfusion with CPB priming (Lee 2013; Loeffelbein 2008; McCall 2004; Oliver 2003), one trial examined the effects of FFP transfusion after anaesthetic induction (Kanbak 2011), and two trials examined postoperative transfusion of FFP (Consten 1996; Långström 2008).

Four trials used no additional treatment as a comparator (Kanbak 2011; McCall 2004; Snow 1982; Trimble 1964), four used hydroxyethyl starch (Chong Sung 2006; Kasper 2001; Kyoung 2004; Wilhelmi 2001), four used human albumin solution (Lee 2013; Loeffelbein 2008; Långström 2008; Oliver 2003), one used Gelofusine (Consten 1996), and one used packed red blood cells (Martinowitz 1990).

\section{Studies of interventions comparing clinical plasma (any type) or plasma-derived blood products}

One trial compared FFP with an active comparator (Tølløfsrud 2003). This trial compared two types of FFP (Uniplas and Octaplas) and was the only trial assessing the therapeutic use of FFP for reversal of warfarin, increase of heparin effect in cases of low antithrombin III, non-surgical bleeding after optimising coagulation status or massive surgical bleeding. 


\section{Outcomes}

No trial measured all outcomes of interest to this review. Six trials reported data for our primary outcome of mortality at 30 days or whilst in hospital (Chong Sung 2006; Kanbak 2011; Långström 2008; McCall 2004; Oliver 2003; Wilhelmi 2001).

\section{Excluded studies}

We excluded 23 studies from the review following full-text eligibility assessment (see Characteristics of excluded studies table).

In summary, 12 had an incorrect intervention: six were trials of plasmapheresis (Armellin 2001; Boldt 1989; Boldt 1990; Boldt 1993; Menges 2006; Safwat 2002); three were trials of FFP for warfarin reversal (Demeyere 2010; Frenzel 2008; Yiu 2006), one was of platelet-rich plasma compared to whole blood (Hertfelder 1992); one trial compared a combination of FFP and human albumin to hydroxyethyl starch (von Sommoggy 1990), and one was two comparisons of the same product (Lancé 2012). Three excluded studies were not randomised controlled trials comparing FFP to a comparator (Bilgin 2011; Chapanduka 2002; Haubelt 2002), three studies were secondary citations for other studies (Demeyere 2010; Miao 2015; Tølløfsrud 2003), three were ongoing trials (ACTRN12613001279718; EudraCT:
2009-016709-41; EudraCT: 2014-000452-28) and two were studies awaiting classification (Miao 2014; Miao 2015).

Of note, papers by the clinician Dr J Boldt have recently been retracted by journals due to a suspected fabrication of results ( Wise 2013): four of the excluded studies relate to the work of this clinician (Boldt 1989; Boldt 1990; Boldt 1993; Menges 2006).

\section{Ongoing studies}

We identified three ongoing studies (see Characteristics of ongoing studies table). We will monitor the progress of these trials and on publication (assuming eligibility) we will include them in future updates of this review. One ongoing RCT compares FFP to fibrinogen concentrate for patients undergoing repair of thoraco-abdominal aortic aneurysms (EudraCT: 2009-016709-41); one is a study of FFP or prothrombin concentrate for treatment of bleeding in cardiac surgery (ACTRN12613001279718); and the last is a study of two types of FFP for patients undergoing emergency surgery for thoracic aortic dissections (EudraCT: 2014-000452-28).

\section{Risk of bias in included studies}

See the 'Risk of bias' tables for details of our assessment for each study and Figure 2 for a tabular summary. 
Figure 2. 'Risk of bias' summary: authors' judgements about each risk of bias item for each included study.

\begin{tabular}{|c|c|c|c|c|c|c|c|c|c|}
\hline & 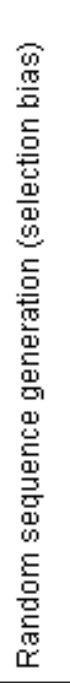 & 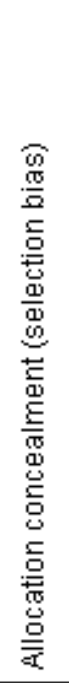 & 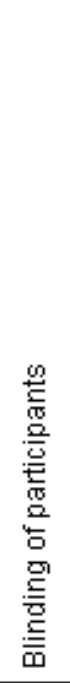 & 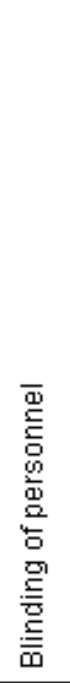 & 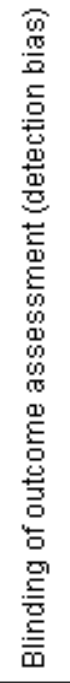 & 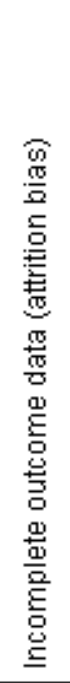 & 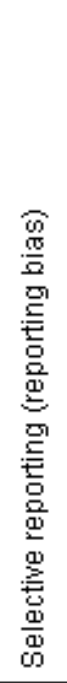 & 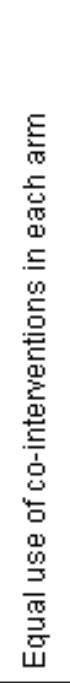 & 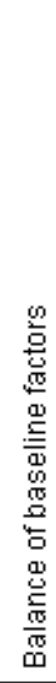 \\
\hline Chong Sung 2006 & $?$ & $?$ & $?$ & $?$ & $?$ & + & + & - & + \\
\hline Consten 1996 & ? & $?$ & + & 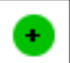 & $?$ & + & + & + & + \\
\hline Kanbak 2011 & ? & $?$ & $?$ & $\odot$ & $?$ & 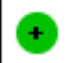 & $\odot$ & - & 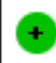 \\
\hline Kasper 2001 & $\odot$ & $\odot$ & $\odot$ & $\odot$ & - & + & + & 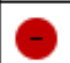 & + \\
\hline Kyoung 2004 & ? & $?$ & $?$ & $?$ & $?$ & + & + & - & + \\
\hline Lăngström 2008 & $?$ & $?$ & + & $?$ & $?$ & + & + & + & $?$ \\
\hline Lee 2013 & $?$ & $?$ & $?$ & + & $?$ & + & + & - & + \\
\hline Loeffelbein 2008 & ? & $?$ & + & $?$ & $?$ & + & + & - & + \\
\hline Martinowitz 1990 & $?$ & $?$ & $?$ & $?$ & $?$ & - & $\odot$ & 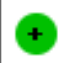 & + \\
\hline Mccall 2004 & ? & $?$ & + & - & $?$ & $?$ & + & - & + \\
\hline Oliver 2003 & $?$ & $?$ & $?$ & $\odot$ & $?$ & + & $\odot$ & - & + \\
\hline Snow 1982 & $\odot$ & $?$ & $?$ & $\odot$ & $?$ & + & 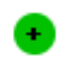 & + & $?$ \\
\hline Trimble 1964 & + & $?$ & $?$ & $?$ & $?$ & 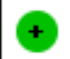 & $\oplus$ & $?$ & $?$ \\
\hline Tølløfsrud 2003 & ? & $?$ & $?$ & $\odot$ & $?$ & $\odot$ & $?$ & 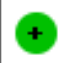 & + \\
\hline Wilhelmi 2001 & 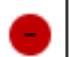 & م & & - & - & + & + & + & + \\
\hline
\end{tabular}




\section{Allocation}

Four trials reported details of the randomisation sequence (Kasper 2001; Snow 1982; Trimble 1964; Wilhelmi 2001). We defined two of these four trials as being of low risk of bias using the following techniques: a computer-generated list and sealed envelopes (Kasper 2001); and random number tables (Trimble 1964). We defined two trials as being of high risk of bias with one using hospital number for randomisation (Snow 1982), and one randomising the first 60 patients to the treatment arm and next 60 to control (Wilhelmi 2001).

We defined the generation of the randomisation sequence as unclear risk of bias in the other 11 trials (Chong Sung 2006; Consten 1996; Kanbak 2011; Kyoung 2004; Lee 2013; Loeffelbein 2008; Långström 2008; McCall 2004; Martinowitz 1990; Oliver 2003; Tølløfsrud 2003).

\section{Concealment of treatment allocation}

Seven trials reported sufficient details to allow an assessment of the quality of the concealment of treatment allocation. We deemed the method of randomisation (as described above) to conceal treatment allocation to be of high risk of bias in two trials (Kasper 2001; Wilhelmi 2001), where there was no concealment in one trial as block randomisation was used (Wilhelmi 2001), and the other used autologous plasma donation pre-procedurally for patients in the FFP group only (Kasper 2001). Four trials used sealed envelopes for randomisation but it was unclear if they were serially numbered or opaque envelopes and we defined them as having an unclear risk of bias (Consten 1996; Lee 2013; McCall 2004; Tølløfsrud 2003).

Nine trials did not provide information to enable assessment of adequate allocation concealment (Chong Sung 2006; Kanbak 2011; Kyoung 2004; Loeffelbein 2008; Långström 2008; Martinowitz 1990; Oliver 2003; Snow 1982; Trimble 1964), and we thus defined them as having unclear risk of bias.

\section{Blinding}

\section{Participants}

Five trials provided adequate information for an assessment of bias for blinding of participants (Consten 1996; Kasper 2001; Loeffelbein 2008; McCall 2004; Wilhelmi 2001). We considered four of these trials to be at low risk of bias as the randomisation was intra-operative (Consten 1996), or the participants were neonates or infants (Loeffelbein 2008; Långström 2008; McCall 2004). We considered two trials to be at high risk of bias for blinding of participants, as one involved autologous collection of plasma only for those in the treatment arm (Kasper 2001), and the other used block randomisation where the first 60 patients received the intervention and the second 60 patients received a control (Wilhelmi 2001). Nine trials did not report sufficient information for an assessment of bias to be made (Chong Sung 2006; Kanbak 2011; Kyoung 2004; Lee 2013; Martinowitz 1990; Oliver 2003; Snow 1982; Trimble 1964; Tølløfsrud 2003).

\section{Study personnel}

Eight trials provided adequate information for an assessment of bias for blinding of study personnel (Consten 1996; Kanbak 2011; Kasper 2001; Lee 2013; McCall 2004; Oliver 2003; Snow 1982; Wilhelmi 2001). We considered three of these trials to be at low risk of bias as in two trials all personnel except the infusionist were blinded (Lee 2013; Oliver 2003), and in another independent investigators were used in the operating room and intensive care unit (Consten 1996). We considered five trials to be at high risk of bias for blinding of personnel, as in three trials personnel in the operating department would either administer FFP or no treatment (Kanbak 2011; McCall 2004; Snow 1982); one involved autologous collection of plasma only for those in the treatment arm and was not blinded (Kasper 2001), and one used block randomisation where the first 60 patients received the intervention and the second 60 patients received a control (Wilhelmi 2001). Seven trials did not report sufficient information for an assessment of bias to be made (Chong Sung 2006; Kyoung 2004; Loeffelbein 2008; Långström 2008; Martinowitz 1990; Trimble 1964; Tølløfsrud 2003).

\section{Outcome assessors}

Two trials provided adequate information for an assessment of bias for blinding of outcome (Kasper 2001; Wilhelmi 2001). Both of these trials were not blinded. Thirteen trials did not report sufficient information for an assessment of bias to be made (Chong Sung 2006; Consten 1996; Kanbak 2011; Kyoung 2004; Lee 2013; Loeffelbein 2008; Långström 2008; Martinowitz 1990; McCall 2004; Oliver 2003; Snow 1982; Trimble 1964; Tølløfsrud 2003).

Overall, the blinding of all trial personnel (patients, clinicians and outcome assessors) to treatment allocation was unclear in five trials (Chong Sung 2006; Kyoung 2004; Martinowitz 1990; Trimble 1964; Tølløfsrud 2003).

\section{Incomplete outcome data}

Ten trials included all randomised patients in the analysis of outcome data and did not lose any patients during follow-up (Chong Sung 2006; Consten 1996; Kanbak 2011; Kyoung 2004; 
Loeffelbein 2008; McCall 2004; Oliver 2003; Tølløfsrud 2003; Trimble 1964; Wilhelmi 2001).

Two trials excluded patients before they received the intervention and reported the reasons for this exclusion (Kasper 2001; Snow 1982); we considered them at low risk of bias. Two trials excluded two patients due to pre-specified complications after randomisation (Lee 2013; Långström 2008), and we also considered them to have a low risk of bias. We considered one trial to have a high risk of bias, as it had a cross-over design and it was unclear when patients were assessed for outcomes before or after the cross-over (Martinowitz 1990).

\section{Selective reporting}

Fourteen studies reported results for all pre-specified outcomes and we considered them to have low risk of bias (Chong Sung 2006; Consten 1996; Kanbak 2011; Kasper 2001; Kyoung 2004; Lee 2013; Loeffelbein 2008; Långström 2008; Martinowitz 1990; McCall 2004; Oliver 2003; Snow 1982; Tølløfsrud 2003; Wilhelmi 2001). One study did not pre-specify any outcomes and its risk of bias was unclear (Trimble 1964).

\section{Other threats to validity}

\section{Balance of baseline factors}

Thirteen studies reported adequate information for a comparison of baseline factors and we considered them at low risk of bias (Chong Sung 2006; Consten 1996; Kanbak 2011; Kasper 2001; Kyoung 2004; Lee 2013; Loeffelbein 2008; Långström 2008; Martinowitz 1990; McCall 2004; Oliver 2003; Tølløfsrud 2003; Wilhelmi 2001). Two studies did not report adequate information to assess baseline factors and we considered them to have unclear risk of bias (Snow 1982; Trimble 1964).

Twelve trials only included patients undergoing elective surgery (Chong Sung 2006; Consten 1996; Kanbak 2011; Kasper 2001; Kyoung 2004; Lee 2013; Loeffelbein 2008 Martinowitz 1990; McCall 2004; Oliver 2003; Snow 1982; Tølløfsrud 2003). Two trials did not specify if emergency cases were included (Långström 2008; Trimble 1964). One trial included emergency patients but only two patients out of 120 were emergency cases and both were randomised to the control group (Trimble 1964). It was not specified if either of the emergency cases were following cardiac arrest or cardiac catheterisation. Nine studies excluded patients with pre-existing coagulopathies (Chong Sung 2006; Consten 1996; Kanbak 2011; Kasper 2001; Kyoung 2004; Lee 2013; McCall 2004; Oliver 2003; Wilhelmi 2001). The remaining six trials did not include any information on the number of with coagulopathies (Loeffelbein 2008; Långström 2008; Martinowitz 1990; Snow 1982; Trimble 1964; Tølløfsrud 2003).

A mix of children and neonates with and without cyanotic heart disease were included in the eight studies that included children
(Chong Sung 2006; Kyoung 2004; Lee 2013; Loeffelbein 2008; Långström 2008; McCall 2004; Oliver 2003; Trimble 1964). For those where information was available, 35/145 (24\%) of children or neonates who were randomised to FFP had congenital cyanotic heart disease compared to $36 / 147$ (24\%) who were randomised to a comparator.

Patients with significant left ventricular failure were excluded from four studies (Consten 1996; Kanbak 2011; Kasper 2001; Wilhelmi 2001). Patients with renal failure were excluded from three studies (Chong Sung 2006; Kanbak 2011; Kasper 2001). Coagulopathic patients were excluded from nine trials (Chong Sung 2006; Consten 1996; Kanbak 2011; Kasper 2001; Kyoung 2004; Lee 2013; McCall 2004; Oliver 2003; Wilhelmi 2001).

Patients taking oral anticoagulants were excluded from four studies (Kanbak 2011; Kasper 2001; Kyoung 2004; McCall 2004), and patients taking antiplatelet agents were excluded from four studies (Kanbak 2011; Martinowitz 1990; McCall 2004; Wilhelmi 2001). No trial where patients were taking antiplatelet agents or anticoagulant drugs described the preoperative management for these patients.

\section{Equal use of co-interventions in each arm}

Six studies had equal use of co-interventions in all study arms and we considered them at low risk of bias (Consten 1996; Långström 2008; Martinowitz 1990; Snow 1982; Tølløfsrud 2003; Wilhelmi 2001). There was insufficient information from one study to assess risk of bias for this domain (Trimble 1964).

Eight studies had a high risk of bias for this domain (Chong Sung 2006; Kanbak 2011; Kasper 2001; Kyoung 2004; Lee 2013; Loeffelbein 2008; McCall 2004; Oliver 2003). In all of these trials, both the FFP and control groups received additional FFP with a higher dose of FFP being transfused in the comparator arm than the FFP arm in six of these trials (Chong Sung 2006; Kanbak 2011, Kasper 2001; Kyoung 2004; Lee 2013; Oliver 2003). Additionally, cryoprecipitate was administered as a co-intervention in two trials (McCall 2004; Oliver 2003), thus confounding the interpretation of fibrinogen concentration.

Equal doses of heparin were used for loading prior to cardiopulmonary bypass in all studies. One trial used 250 units heparin/kg (Kyoung 2004), seven trials used 300 units heparin/kg (Consten 1996; Kanbak 2011; Kasper 2001; Lee 2013; Oliver 2003; Snow 1982; Trimble 1964), one trial used 350 units heparin/kg (Wilhelmi 2001), and one trial used 400 units heparin/kg (Tølløfsrud 2003).

Nine trials reported on whether heparin was used for the cardiopulmonary bypass priming (Consten 1996; Kanbak 2011; Kasper 2001; Kyoung 2004; Lee 2013; Loeffelbein 2008; McCall 2004; Oliver 2003). Four trials did not used heparin for the cardiopulmonary bypass priming (Consten 1996; Kyoung 2004; Oliver 2003; Wilhelmi 2001), one trial used 50 units/kg heparin (Kanbak 2011), one trial used 750 units heparin with a standard deviation 
of 250 units heparin (Loeffelbein 2008), one trial used 1400 to 2000 units heparin (McCall 2004), one trial used 2000 units heparin (Kasper 2001), and in one study the total dose was unclear (Lee 2013). Heparin levels were adjusted perioperatively. There was equal use of heparin loading and heparin priming in the FFP and comparator groups.

The dose of protamine for heparin reversal was described in nine trials (Consten 1996; Kanbak 2011; Kyoung 2004; Lee 2013; Oliver 2003; Trimble 1964; Tølløfsrud 2003; Wilhelmi 2001). Two studies used 1 unit protamine per unit of heparin (Kanbak 2011; Lee 2013), one trial used $3 \mathrm{mg}$ protamine per 100 units heparin (Trimble 1964), one trial used $5 \mathrm{mg}$ to $10 \mathrm{mg}$ protamine $/ \mathrm{kg}$ body weight (Kyoung 2004), one trial used 300 units protamine/ $\mathrm{kg}$ body weight (Wilhelmi 2001), one study used $1.3 \mathrm{mg} / 100$ units heparin (Oliver 2003), and one study used $1.5 \mathrm{mg}$ protamine per 125 units heparin (Consten 1996). FFP and control groups were administered an equal amount of protamine in all studies where this was reported.

Aprotinin was administered to all patients in two trials (Långström 2008; Wilhelmi 2001). One million units of aprotinin was administered to all patients before priming in one trial (Wilhelmi 2001). In the other trial using aprotinin, 30,000 units $/ \mathrm{kg}$ aprotinin was given in the priming solution, followed by a bolus of 30,000 units $/ \mathrm{kg}$, followed by 8000 units $/ \mathrm{kg} /$ hour maintenance (Långström 2008). Patients in the FFP and comparator arms were treated equally. No other study reported use of antifibrinolytic agents.

Duration of cardiopulmonary bypass was similar between patents who received FFP and those who received a comparator.

\section{Effects of interventions}

See: Summary of findings for the main comparison Fresh frozen plasma compared to no plasma for cardiovascular surgery

\section{Studies of interventions comparing any clinical plasma transfusion with no plasma}

Fourteen studies compared fresh frozen plasma (FFP) transfusion with no FFP (Chong Sung 2006; Consten 1996; Kanbak 2011; Kasper 2001; Kyoung 2004; Lee 2013; Loeffelbein 2008; Martinowitz 1990; McCall 2004; Oliver 2003; Snow 1982; Trimble 1964; Wilhelmi 2001). All of these studies used FFP, or the comparator, for prophylaxis of bleeding. One trial administered FFP (or comparator) pre-operatively with anaesthetic induction (Kanbak 2011); four trials administered FFP (or comparator) intra-operatively with cardiopulmonary bypass (CPB) priming (Lee 2013; Loeffelbein 2008; McCall 2004; Oliver 2003); seven studies administered FFP (or comparator) intra-operatively after CPB termination and heparin neutralisation (Chong Sung 2006; Kasper 2001; Kyoung 2004; Martinowitz 1990; Snow 1982; Trimble 1964; Wilhelmi 2001), and in two studies FFP (or compara- tor) was administered postoperatively (Consten 1996; Långström 2008).

We have not included outcome data from the Martinowitz 1990 study in this systematic review, due to a major methodological problem in the study design. The authors did not clearly define a uniform time point where cross-over took place and hence it was not possible to assess the outcome data by individual intervention. This meant that it was impossible to fully understand the data in this trial and we took the decision to not include this trial in any quantitative or qualitative assessment of outcome data.

\section{Primary outcomes}

\section{Short-term mortality rate (30 days or in hospital)}

Six trials (with 287 patients) reported measuring mortality (Chong Sung 2006; Kanbak 2011; Långström 2008; McCall 2004; Oliver 2003; Wilhelmi 2001), although mortality was not the primary outcome for any of them. In five trials there were no incidences of mortality (Chong Sung 2006; Kanbak 2011; Långström 2008; McCall 2004; Wilhelmi 2001). One trial measuring perioperative mortality found no difference in the number of deaths between the intervention arms (Oliver 2003). Hence a pooled result could not be obtained, but the data are depicted in a graph (Analysis 1.1). There was a very serious risk of imprecision in this estimate due to the low numbers of mortality events and a serious risk of bias due to inadequate or unclear sequence generation in the trials contributing towards this outcome. Consequently, we downgraded the quality of evidence for this outcome to very low.

\section{Secondary outcomes}

\section{Major complications: serious organ damage - respiratory failure}

No trial reported respiratory failure as an outcome.

Major complications: serious organ damage - myocardial infarction

One trial reported myocardial infarction as an outcome (Wilhelmi 2001). In this trial, there were no myocardial infarctions in either study group (Analysis 1.2).

\section{Major complications: serious organ damage - stroke}

No trial reported the incidence of stroke as an outcome. 


\section{Major complications: serious organ damage - renal failure}

One trial reported renal failure as an outcome (Loeffelbein 2008). There was a significant difference in favour of the comparator group (no FFP) in the mean glomerular filtration rate six hours after cardiopulmonary bypass (mean difference (MD) $-48.3 \mathrm{ml}$ / $\mathrm{min} / 1.73 \mathrm{~m}^{2}, 95 \%$ confidence interval (CI) -48.3 to $-6.87 \mathrm{ml} /$ $\min / 1.73 \mathrm{~m}^{2}, 20$ patients) (Analysis 1.3).

\section{Major complications: serious organ damage - haemorrhage (measured as the presence or absence of major/unexpected bleeding and, if stated, the volume of blood loss)}

Eleven trials reported blood loss postoperatively (Chong Sung 2006; Consten 1996; Kanbak 2011; Kasper 2001; Kyoung 2004; Lee 2013; McCall 2004; Oliver 2003; Snow 1982; Trimble 1964; Wilhelmi 2001).

We analysed paediatric and neonatal patients separately from adult patients, as there were differences in the volume of blood loss and units of measure between these groups of patients $(\mathrm{ml} / \mathrm{kg}$ for paediatric patients and neonates and $\mathrm{ml}$ for adults).

Four studies in paediatric and neonatal patients (Chong Sung 2006; Kyoung 2004; McCall 2004; Oliver 2003), and one study in adults (Wilhelmi 2001), provided data that could be pooled in a meta-analysis. There was no significant difference in blood loss at 24 hours between the FFP and the comparator group in the paediatric and neonatal patients (MD $-1.46 \mathrm{ml} / \mathrm{kg} / 24$ hours, $95 \%$ CI -4.7 to $1.78 \mathrm{ml} / \mathrm{kg} / 24$ hours, 138 patients) (Analysis 1.4 ), or for the adults (MD $-12.00 \mathrm{ml} / 24$ hours, $95 \% \mathrm{CI}-101.16$ to $77.16 \mathrm{ml} / 24$ hours, 120 patients). One study was a significant outlier (Oliver 2003). There was no difference in the $\mathrm{I}^{2}$ value when we removed it in sensitivity analysis, so we included it with the other studies. The higher mean volume of blood loss in this study compared with the other studies in children is likely to be related to the higher complexity of the surgery that patients underwent, as a high proportion of patients in this trial had surgery for cyanotic congenital heart disease. There was a very serious risk of bias for this outcome due to inadequate or unclear sequence generation and inadequate blinding of participants, clinicians and/or analysts. Consequently we downgraded the quality of the evidence to low. In another six studies, variability in the method of statistical analysis and reporting (Kasper 2001; Lee 2013), and not reporting the timing of the measurement of the outcome (Consten 1996; Kanbak 2011; Snow 1982; Trimble 1964), prevented these trials from being included in the meta-analysis. Kasper 2001 and Lee 2013 presented blood loss at 24 hours as a median (plus interquartile range). The FFP group had less blood loss at 24 hours when compared to the comparator (no FFP group) in Kasper 2001 and in the children (age one to 16 years) randomised in the Lee 2013 study. Infants (age less than 12 months) in Lee 2013 had less blood loss at 24 hours in the comparator group (no FFP) when compared to the FFP group. Median values are reported in Table 1 .
In the four trials that reported blood loss but not the time over which it was measured (Consten 1996; Kanbak 2011; Snow 1982; Trimble 1964), blood loss was lower in the comparator (no FFP) group in Consten 1996, Kanbak 2011 and Snow 1982 and greater in both children and adults in the FFP group in Trimble 1964. Individual study data are reported in Table 1.

Transfusion requirements (for example, red cells, platelets, plasma, cryoprecipitate, plasma-derived products such as prothrombin complex concentrates or albumin) or use of non-blood products such as recombinant factor VIIa

\section{Red cells}

Ten studies reported red cell transfusion as an outcome (Chong Sung 2006; Consten 1996; Kanbak 2011; Kasper 2001; Kyoung 2004; Lee 2013; McCall 2004; Oliver 2003; Snow 1982; Wilhelmi 2001), and one study reported red cell transfusion requirements as its primary outcome (McCall 2004).

We analysed volume of red cells transfused separately for adult and paediatric/neonatal patients, as there were differences in the volume of blood loss and units of measure $(\mathrm{ml} / \mathrm{kg}$ for paediatric patients and neonates and $\mathrm{ml}$ for adults) between these groups of patients.

Three paediatric and neonatal studies provided data that could be pooled in a meta-analysis (Chong Sung 2006; Kyoung 2004; Oliver 2003). Only one adult study reported this outcome (Kanbak 2011). There was no significant difference in red cell transfusions at 24 hours between the FFP and the comparator group in the paediatric and neonatal patients (MD $0.4 \mathrm{ml} / \mathrm{kg} /$ 24 hours, $95 \%$ CI -2.99 to $3.79 \mathrm{ml} / \mathrm{kg} / 24$ hours, 110 patients) (Analysis 1.5). There was also no difference observed in the one adult study (MD $150.00 \mathrm{ml} / 24$ hours, $95 \%$ CI -128.63 to 428.63 $\mathrm{ml} / 24$ hours, 32 patients). There was a very serious risk of bias for this outcome due to inadequate or unclear sequence generation and inadequate blinding of participants, clinicians and/or analysts. Consequently we downgraded the quality of the evidence to low. In another six studies, variability in the method of statistical analysis (Kasper 2001; Lee 2013) and the unit of measurement (Consten 1996; McCall 2004; Snow 1982; Wilhelmi 2001) prevented these trials from being included in the meta-analysis.

Kasper 2001 and Lee 2013 presented red blood cell transfusion requirement at 24 hours as a median (plus interquartile range). The FFP group had a lower red blood cell transfusion requirement then the comparator (no FFP group) in both studies. Median values are reported in Table 2 . In the three trials using different units of measurement to report this outcome, the volume of red blood cells transfused within the first 24 hours was greater in the comparator (no FFP) group when compared to the FFP group in Consten 1996; the number of units transfused per patient in the first 24 hours was greater in the FFP group when compared to the 
comparator (no FFP) group in Wilhelmi 2001 and Snow 1982. Individual study data are reported in Table 2.

Four studies reported information on the number of patients who received any red cell transfusion and all provided sufficient information for use in meta-analysis (Kanbak 2011; McCall 2004; Oliver 2003; Wilhelmi 2001). We analysed paediatric and adult studies together for this outcome. There was a significant difference in favour of control in the number of patients who required a red cell transfusion (Peto odds ratio (OR) 2.57, 95\% CI 1.30 to 5.08, 222 patients) (Analysis 1.6). There was a very serious risk of bias for this outcome due to inadequate or unclear sequence generation and inadequate blinding of participants, clinicians and/ or analysts. However, there was a large treatment effect. Consequently we downgraded the quality of the evidence to moderate.

\section{Platelets}

Three studies reported platelet transfusion requirements as an outcome (Lee 2013; McCall 2004; Oliver 2003). All were in a neonate and paediatric population but differences in the units of measurement prevented the pooling of data in a meta-analysis (Analysis 1.7). McCall 2004 measured platelet usage by the mean (standard deviation (SD)) number of donor exposures; Oliver 2003 by the mean (SD) number of units used in the operating theatre and during the initial 24 hours in the intensive care unit (ICU) and Lee 2013 reports data as median (plus interquartile range).

In Lee 2013, platelet transfusion requirement was very similar between the FFP and comparator (no FFP group); median values are reported in Table 3. However, in McCall 2004 and Oliver 2003, platelet usage in the FFP group was lower than in the comparator (no FFP group). Individual study data are reported in Table 3

\section{Cryoprecipitate}

Two studies reported cryoprecipitate transfusions as an outcome (McCall 2004, Oliver 2003). Both studies were in a neonate and paediatric population but differences in the units of measurement prevented the pooling of data in a meta-analysis (Analysis 1.8). McCall 2004 measures cryoprecipitate usage by the mean (SD) number of donor exposures and Oliver 2003 by the mean (SD) number of units used in the operating theatre and during the initial 24 hours in the ICU.

In Oliver 2003, cryoprecipitate usage was very similar between the FFP and comparator (no FFP group). However, in McCall 2004 cryoprecipitate usage in the FFP group was lower than in the comparator (no FFP group). Individual study data are reported in Table 4.

\section{Use of FVIIa or antifibrinolytic drugs to control bleeding}

No trial reported the use of FVIIa or antifibrinolytic drugs to control bleeding as an outcome.

\section{Measurement of coagulation factors or tests (by prothrombin time, activated partial thromboplastin time or equivalent)}

\section{Prothrombin time}

Nine studies reported prothrombin time measured within two hours of FFP transfusion (Consten 1996; Kanbak 2011; Kasper 2001; Kyoung 2004; Lee 2013; McCall 2004; Oliver 2003; Snow 1982; Wilhelmi 2001). Five studies provided data that could be pooled in a meta-analysis (Consten 1996; Kanbak 2011; McCall 2004; Oliver 2003; Snow 1982). There was a difference in prothrombin time measured within two hours of FFP transfusion: the mean prothrombin time was reduced in the FFP arm in comparison to the comparator arm (MD -0.71 seconds, 95\% CI 1.28 to $-0.13,210$ patients, $\mathrm{I}^{2}=0 \%$ ) (Analysis 1.9 ). There was a serious risk of bias for this outcome due to inadequate or unclear sequence generation. Consequently we downgraded the quality of the evidence to moderate.

Four studies were not included in the meta-analysis (Kasper 2001; Kyoung 2004; Lee 2013; Wilhelmi 2001). Two studies reported prothrombin time as a percentage (Kasper 2001; Wilhelmi 2001); one reported prothrombin time as the international normalised ratio (Kyoung 2004); and one reported prothrombin time 24 hours after transfusion (Lee 2013), so these were not included in metaanalysis. Three of these studies reported a trend in favour of FFP (Kasper 2001; Kyoung 2004; Wilhelmi 2001), and one showed no difference between FFP and control (Lee 2013). Individual study data are reported in Table 5.

\section{Activated partial thromboplastin time (APTT)}

Nine studies reported data for this outcome (Chong Sung 2006; Consten 1996; Kanbak 2011; Kasper 2001; Kyoung 2004; Lee 2013; McCall 2004; Oliver 2003; Wilhelmi 2001), with eight studies providing data that could be pooled in a meta-analysis (Chong Sung 2006; Consten 1996; Kanbak 2011; Kasper 2001; Kyoung 2004; McCall 2004; Oliver 2003; Wilhelmi 2001) (Analysis 1.10). However, the $\mathrm{I}^{2}$ statistic is $96 \%$, which signifies substantial statistical heterogeneity. We did explore two possible causes: patient age and timing of measurement after protamine administration. Removing the neonate and paediatric data from the analysis did not change the $\mathrm{I}^{2}$ when the data from just the four trials in an adult population were pooled (Consten 1996; Kanbak 2011; Kasper 2001; Wilhelmi 2001); nor did removing the data from the three trials where measurement of FFP was delayed until ICU admission postoperatively (McCall 2004; Oliver 2003; Wilhelmi 2001). The differences observed are likely to be

Fresh frozen plasma for cardiovascular surgery (Review) 
due to methodological differences, as activated partial thromboplastin (APTT) time is dependent on heparin concentration and protamine infusion as well as FFP. The cause of the substantial heterogeneity is likely to be a result of the timing of APTT measurement compared to timing of heparin neutralisation with protamine.

Overall, four studies reported that activated partial thromboplastin time was shorter after FFP transfusion than controls (Chong Sung 2006; Kasper 2001; Kyoung 2004; Oliver 2003); three studies found that activated partial thromboplastin time was shorter for controls than after FFP transfusion (Consten 1996; Kanbak 2011; Wilhelmi 2001), and one study found no difference between FFP transfusion and controls (McCall 2004). Individual study data are reported in Table 6.

Lee 2013 reported activated partial thromboplastin time 24 hours postoperatively as median values (with interquartile range). APTT levels were lower in the FFP group when compared to the comparator (no FFP) group for both infants and children. Individual study data are reported in Table 6.

\section{Fibrinogen concentration}

Five studies measured fibrinogen concentration within two hours of the study products being transfused and all had the potential to be combined for meta-analysis (Kasper 2001; Lee 2013; McCall 2004; Oliver 2003; Snow 1982) (Analysis 1.11). The $\mathrm{I}^{2}$ statistic was $82 \%$, which signifies substantial statistical heterogeneity. We did explore two possible causes: patient age and type of comparator. Removing the neonate and paediatric data from the analysis did not reduce the amount of statistical heterogeneity (measured through the $\mathrm{I}^{2}$ ) when the data from the two trials in an adult population were pooled (Kasper 2001; Snow 1982). In four of these studies some patients in the control group also received FFP alongside the non-FFP comparator (Kasper 2001; Lee 2013; McCall 2004; Oliver 2003). In two of the studies patients in the control group also received cryoprecipitate, another source of fibrinogen (McCall 2004; Oliver 2003). These factors are likely to account for the observed heterogeneity. Consequently, a pooled analysis is not reported.

Four trials found that fibrinogen concentration was greater after FFP transfusion than controls (Kasper 2001; Lee 2013; Oliver 2003; Snow 1982). One study found that fibrinogen concentration was greater after control infusion than after FFP transfusion (McCall 2004). Individual study data are reported in Table 7.

\section{Adverse events}

No trial reported adverse events as an outcome.

\section{Resource use: length of hospital stay}

No trial reported length of hospital stay as an outcome.

\section{Resource use: time in operating theatre or intensive care unit}

Two studies reported time in intensive care (Oliver 2003, Wilhelmi 2001). No difference was found in the time in the operating theatre or intensive care unit between the FFP and comparator arm (no FFP) in either trial (Analysis 1.12). One of these trials recruited adults (Wilhelmi 2001), and the other recruited children (Oliver 2003); this is likely to account for the differences in the time spent in the ICU.

\section{Resource use: need for return to theatre/reoperation for management of bleeding}

Seven studies reported this outcome (Chong Sung 2006; Kasper 2001; Kyoung 2004; Oliver 2003; Snow 1982; Trimble 1964; Wilhelmi 2001). Trimble 1964 reported children and adults separately. There was no difference in the number of patients returning to theatre for a re-operation between the FFP and comparator (no FFP) group (Peto OR 0.81, 95\% CI 0.26 to $2.57,398$ patients) (Analysis 1.13). There was a serious risk of bias for this outcome due to inadequate or unclear sequence generation. Consequently we downgraded the quality of the evidence to moderate.

\section{Studies of interventions comparing clinical plasma (any type) or plasma-derived blood product}

One study, using FFP therapeutically, compared two types of FFP: Octaplas and Uniplas (Tølløfsrud 2003). Patients were randomised to Octaplas or Uniplas but the patients in the Uniplas group were then divided into two groups by their blood type. Data are reported as if three distinct randomised groups and as such cannot be part of any quantitative analyses. Outcome findings for this trial are therefore reported descriptively with outcome data presented in Table 8.

\section{Primary outcomes}

\section{Short-term mortality rate (30 days or in hospital)}

Tølløfsrud 2003 reported peri-operative mortality as an outcome. There were more deaths in the Octaplas group than in either Uniplas group. Deaths were reported as due to 'surgical technical problems' unrelated to FFP.

\section{Secondary outcomes}

\author{
Major complications: serious organ damage - respiratory \\ failure
}

Tølløfsrud 2003 reported respiratory failure as an outcome. There were more cases of respiratory failure in the Uniplas group for 
patients with blood group $\mathrm{A}, \mathrm{B}$ or $\mathrm{AB}$ than in the Uniplas group for patients with blood group $\mathrm{O}$ or the Octaplas group.

\section{Major complications: serious organ damage - myocardial infarction}

Tølløfsrud 2003 reported myocardial infarction as an outcome. There were more cases of myocardial infarction in the Octaplas group than in either Uniplas group.

\section{Major complications: serious organ damage - stroke}

Tølløfsrud 2003 reported stroke as an outcome. There were more cases of stroke in the Uniplas group for patients with blood group $\mathrm{O}$ than in the Uniplas group for patients with blood group A, B or $\mathrm{AB}$, or in the Octaplas group.

\section{Major complications: serious organ damage - renal failure}

Tølløfsrud 2003 reported renal failure as an outcome. There were more cases of renal failure in the Uniplas group for patients with blood group $\mathrm{A}, \mathrm{B}$ or $\mathrm{AB}$ than in the Uniplas group for patients with blood group $\mathrm{O}$; or in the Octaplas group.

Major complications: serious organ damage - haemorrhage (measured as the presence or absence of major/unexpected bleeding and, if stated, the volume of blood loss)

Tølløfsrud 2003 reported postoperative bleeding as an outcome. Mean blood loss was highest in the Octaplas group, followed by the Uniplas group for patients with blood group $\mathrm{O}$; followed by patients in the Uniplas group with group $\mathrm{A}, \mathrm{B}$ or $\mathrm{AB}$ blood.

Transfusion requirements (for example, red cells, platelets, plasma, cryoprecipitate, plasma-derived products such as prothrombin complex concentrates or albumin) or use of non-blood products such as recombinant factor VIIa

\section{Red cells}

Tølløfsrud 2003 reported red cell transfusions during the study period as an outcome. Mean red cell transfusions were highest in the Uniplas group with blood group $\mathrm{O}$, followed by the Uniplas group for patients with blood group $\mathrm{A}, \mathrm{B}$ or $\mathrm{AB}$, followed by patients in the Octaplas group.

\section{Platelets}

Tølløfsrud 2003 reported platelet transfusions during the study period as an outcome. Mean platelet transfusions were highest in the Uniplas group with blood group A, B or A, followed by the Octaplas group, followed by patients in the Uniplas group with group O blood.

\section{Cryoprecipitate}

No data were reported for this outcome

\section{Use of FVIIa or antifibrinolytic drugs to control bleeding}

No data were reported for this outcome.

Measurement of coagulation factors or tests (by prothrombin time, activated partial thromboplastin time, or equivalent)

\section{Prothrombin time}

No data were reported for this outcome.

\section{Activated partial thromboplastin time}

Tølløfsrud 2003 reported mean activated partial thromboplastin time as an outcome. Activated partial thromboplastin time was highest in the Uniplas group for patients with blood group A, B or $\mathrm{AB}$, followed by the Uniplas group for patients with blood group $\mathrm{O}$, then the Octaplas group.

\section{Fibrinogen concentration}

No data were reported for this outcome.

\section{Adverse events}

Tølløfsrud 2003 reported allergic and haemolytic transfusion reactions as an outcome. No adverse events were reported in any of the groups.

\section{Resource use: length of hospital stay}

No data were reported for this outcome.

Resource use: time in operating theatre or intensive care unit No data were reported for this outcome. 
Resource use: need for return to theatre/reoperation for management of bleeding

Tølløfsrud 2003 reported return to theatre as an outcome. Return to theatre was more common in the Octaplas group than in either Uniplas group.

\section{ISCUSSION}

\section{Summary of main results}

We included 15 trials in this systematic review with a total of 755 patients. One of these trials assessed the use of fresh frozen plasma (FFP) therapeutically (Tølløfsrud 2003). Tølløfsrud 2003 compared two types of FFP for the treatment of unexpected surgical bleeding, for the reversal of warfarin or for antithrombin supplementation. As this trial compared two types of FFP, it is difficult to draw conclusions about the efficacy of FFP in this setting. The remaining 14 trials examined prophylactic FFP use in elective cardiac surgery and we will consider these in more detail in this discussion. The timing of intervention varied, including FFP transfusion at the time of heparin neutralisation and stopping cardiopulmonary bypass (CPB) (seven trials), with $\mathrm{CPB}$ priming (four trials), after anaesthesia induction (one trial) and postoperatively (two trials).

Twelve trials only included elective patients and in the one trial that explicitly included emergency patients, these made up 2/120 of the total. Coagulopathic patients were excluded from nine trials and these excluded patients may be those that would benefit most from FFP. Patients who were receiving antiplatelet agents or anticoagulant drugs were excluded from four trials each and these patients may be more likely to bleed.

There was no difference in mortality between patients who received FFP and a comparator, although the number of deaths was small (Analysis 1.1). There was no significant difference in blood loss between those that received FFP and those that did not: paediatric/neonatal patients (mean difference (MD) $-1.46 \mathrm{ml} / \mathrm{kg}$, 95\% confidence interval (CI) -4.7 to $1.78 \mathrm{ml} / \mathrm{kg}$ ); adult patients (MD $-12.00 \mathrm{ml}, 95 \% \mathrm{CI}-101.16$ to $77.16 \mathrm{ml}$ ) (Analysis 1.4). The number of patients who received any red cell transfusion was significantly higher in those transfused with FFP than controls (Peto odds ratio (OR) 2.57, 95\% CI 1.30 to 5.30). There was no difference in red cell transfusion volume (Analysis 1.5), platelet or cryoprecipitate requirements between those receiving FFP and no FFP. There was no significant difference between FFP and no FFP in duration of intensive care unit (ICU) admission or in need to return to theatre for re-operation (OR $0.81,95 \%$ CI 0.26 to 2.57).

There was a statistically significant difference in prothrombin time (Analysis 1.9) and fibrinogen concentration after FFP administration compared to no FFP. However, the differences are small and unlikely to be of clinical significance. There was no significant difference between FFP and comparator for activated partial thromboplastin time.

One included study reported adverse events as an outcome and reported no adverse events due to FFP transfusion. No study reported length of hospital stay.

\section{Overall completeness and applicability of evidence}

The review method aimed for a comprehensive assessment of FFP randomised controlled trials (RCTs) in cardiac and vascular surgery. It identified two trials, Lee 2013 and Snow 1982, not included in the systematic review of FFP use in all specialities (Yang 2012), reflecting the broad and comprehensive searching strategy. The timing of intervention varied, including transfusion at the time of heparin neutralisation and stopping cardiopulmonary bypass (CPB) (seven trials), with $\mathrm{CPB}$ priming (four trials), after anaesthesia induction (one trial) and postoperatively (one trial). This is likely to be an important clinical factor in determining the wider applicability of the evidence.

\section{Quality of the evidence}

The 15 trials included in this review are at risk of bias. There is either high risk of bias, or unclear risk, in the majority of trials included in this review. Overall the trials were small, with only four reporting an a priori sample size calculation, which was achieved in all four trials. No trial was powered to determine changes in mortality as a primary outcome. Ten of the trials are more than 10 years old.

There is heterogeneity in the dose of FFP, timing of administration and patient groups. We found heterogeneity between studies in six cases (defined as an $\mathrm{I}^{2}$ value greater than $50 \%$ ). These outcomes included transfusion requirements for red cells, platelets and cryoprecipitate, all of which are prone to bias in unblinded studies, as a decision on transfusion may be taken by the clinical team. Fibrinogen and activated partial thromboplastin time also showed significant heterogeneity between studies. Fibrinogen can be replaced by cryoprecipitate or fibrinogen concentrate in addition to FFP, and variation in transfusion practice for these blood components may have led to heterogeneity. The main determinant of postoperative activated partial thromboplastin time is heparin concentration/neutralisation and FFP administration is of minimal consequence for this measurement in this clinical situation. We found five outcomes to have low levels of heterogeneity between groups (mortality, bleeding in first 24 hours, prothrombin time after FFP administration, time in ICU and need to return to theatre.

There were insufficient data to calculate heterogeneity for respiratory failure, myocardial infarction, stroke, renal failure, use of 
FVIIa or antifibrinolytic drugs, or length of hospital stay. We found the quality of the evidence to be low to moderate for most outcomes. The outcomes in this review were at risk of bias due to inadequate sequence generation and inadequate blinding of participants, personnel and analysts. The primary outcome of mortality within 30 days was subject to a high level of imprecision due to the low number of deaths in the studies included in the review. This level of imprecision means that further research is likely to alter the estimate of effect.

\section{Potential biases in the review process}

The searching was comprehensive and we minimised bias by using two independent researchers to screen, extract and analyse data. One potential source of bias was not obtaining missing data from the two trials published before 1990 (Snow 1982; Trimble 1964). We were unable to find current contact details for the authors of either trial in order to request the missing data.

\section{Agreements and disagreements with other studies or reviews}

A retrospective study of 5261 patients undergoing coronary bypass surgery found a significant increase in mortality for patients who were transfused with FFP compared to those that were not (Bjursten 2013). Another retrospective study of 967 patients undergoing cardiac surgery transfused with FFP for the treatment of bleeding found no evidence of a beneficial effect of FFP transfusion on mortality (Doussau 2014). These findings concur with our findings that no beneficial effect on mortality was found with FFP transfusion. Our results also concur with a previous systematic review on FFP in a number of surgical and medical settings, where FFP was not found to improve mortality (Yang 2012).

\section{AUTHORS' CONCLUSIONS}

\section{Implications for practice}

This review has found no evidence to support the prophylactic administration of fresh frozen plasma (FFP) to patients without coagulopathy undergoing elective cardiac surgery. There was no significant difference in mortality. Only one included study reported adverse events as an outcome, and reported no adverse events attributable to FFP transfusion. There was a significant increase in the number of patients requiring red cell transfusion who were randomised to FFP. There were statistically significant differences in some laboratory parameters, such as prothrombin time, but this difference was too small to be of clinical significance. Patients undergoing emergency surgery and coagulopathic patients were poorly represented amongst the published studies. The findings question the continued routine practice of prophylactic administration in the absence of coagulopathy or bleeding.

\section{Implications for research}

Further adequately powered studies of FFP are required to assess whether larger reductions in prothrombin time translate into clinical benefits, including mortality reduction. These studies should carefully consider the most appropriate schedule and dose for administration of FFP. There is clinical interest in the role of alternative comparable pro-haemostatic agents (for instance, prothrombin complex concentrate), but clinical trials need to be undertaken to evaluate any prophylactic role. There is insufficient evidence to inform any positive therapeutic role of FFP, which is an important gap in the research agenda (Desborough 2012).

\section{ACKNOWLEDGEMENTS}

We would like to thank Drs Erica Wood, Michael Desmond, Carla Silvani and Prof Chris Hyde for help with development and writing of the protocol.

\section{R E F E R E N C E S}

\section{References to studies included in this review}

Chong Sung 2006 \{published data only\}

* Chong Sung K, Kum Suk P, Mi Ja Y, Kyoung Ok K. Effects of intravascular volume therapy using hydroxyethyl starch $(130 / 0.4)$ on post-operative bleeding and transfusion requirements in children undergoing cardiac surgery: a randomized clinical trial. Acta Anaesthesiologica Scandinavica 2006;50(1):108-11.

Desborough M [per comm]. Effects of intravascular volume therapy using hydroxyethyl starch $(130 / 0.4)$ on post- operative bleeding and transfusion requirements in children undergoing cardiac surgery: a randomized clinical trial. Email to pissces@medimail.co.kr and kimcs@snu.ac.kr for further information 11 December 2014 No reply.

Consten 1996 \{published data only\} Consten EC, Henny CP, Eijsman L, Dongelmans DA, van Oers $\mathrm{MH}$. The routine use of fresh frozen plasma in operations with cardiopulmonary bypass is not justified. Journal of Thoracic and Cardiovascular Surgery 1996;112(1): 162-7.

Fresh frozen plasma for cardiovascular surgery (Review)

Copyright $\odot 2015$ The Cochrane Collaboration. Published by John Wiley \& Sons, Ltd. 
Kanbak 2011 \{published and unpublished data\}

Desborough M [per comm]. Peroperative effects of fresh frozen plasma and antithrombin III on heparin sensitivity and coagulation during nitroglycerine infusion in coronary artery bypass surgery. Email to baharoc@selcuk.edu.tr 11 December 2014 Reply with information on mortality and number of patients who underwent any transfusion on 15 January 2015.

* Kanbak M, Oc B, Salman MA, Ocal T, Oc M. Peroperative effects of fresh frozen plasma and antithrombin III on heparin sensitivity and coagulation during nitroglycerine infusion in coronary artery bypass surgery. Blood Coagulation \& Fibrinolysis 2011;22(7):593-9.

Kasper 2001 \{published data only\}

Desborough M [per comm]. Failure of autologous fresh frozen plasma to reduce blood loss and transfusion requirements in coronary artery bypass surgery. Email to stefan-mario.kasper@medizin.uni-koeln.de for further information 11 December 2014 Email address no longer in use.

* Kasper SM, Giesecke T, Limpers P, Sabatowski R, Mehlhorn U, Diefenbach C. Failure of autologous fresh frozen plasma to reduce blood loss and transfusion requirements in coronary artery bypass surgery. Anesthesiology 2001;95(1):81-6.

Kyoung 2004 \{published data only\}

Desborough M [per comm]. Effects of intravascular volume therapy with a hydroxyethal starch [HES 130/0.4] on blood coagulation in children undergoing cardiac surgery. Email to pissces@medimail.co.kr and kimcs@snu.ac.kr for further information 11 December 2014 No reply.

* Kyoung K, Sun S, Sung KC. Effects of intravascular volume therapy with a hydroxyethal starch [HES 130/ $0.4]$ on blood coagulation in children undergoing cardiac

surgery [심장수술을 시행하는 환아에서 혈장증량제로

사용한 히드록시에칠스타치가 혈액응고에 미치는

영향]. Korean Journal of Anaesthesiology 2004;47(3): 379-84.

Långström 2008 \{published data only\}

Långström S, Rautiainen P, Mildh L, Peltola K, WartiovaaraKautto U, Heikinheimo M, et al. Fresh frozen plasma does not reduce in vivo thrombin formation after neonatal cardiopulmonary bypass surgery. Thrombosis and Haemostasis 2008;100(6):1207-8.

Lee 2013 \{published data only\} Lee JW, Yoo YC, Park HK, Bang SO, Lee KY, Bai SJ. Fresh frozen plasma in pump priming for congenital heart surgery: evaluation of effects on postoperative coagulation profiles using a fibrinogen assay and rotational thromboelastometry. Yonsei Medical Journal 2013;54(3):752-62.

Loeffelbein 2008 \{published data only\} Loeffelbein F, Zirell U, Benk C, Schlensak C, Dittrich S. High colloid oncotic pressure priming of cardiopulmonary bypass in neonates and infants: implications on haemofiltration, weight gain and renal function. European

Journal of Cardio-Thoracic Surgery 2008;34(3):648-52.

Martinowitz 1990 \{published data only\}

Martinowitz U, Goor DA, Ramot B, Mohr R. Is transfusion of fresh plasma after cardiac operations indicated?. Journal of Thoracic and Cardiovascular Surgery 1990;100(1):92-8.

McCall 2004 \{published and unpublished data\}

Desborough M [per comm]. Fresh frozen plasma in the pediatric pump prime: a prospective, randomized trial. Email to bradlesm@musc.edu 11 December 2014 Reply with information on mortality and number of patients who underwent any transfusion on 12 December 2014.

* McCall MM, Blackwell MM, Smyre JT, Sistino JJ, Acsell JR, Dorman BH, et al. Fresh frozen plasma in the pediatric pump prime: a prospective, randomized trial. Annals of Thoracic Surgery 2004;77(3):983-7.

Oliver 2003 \{published and unpublished data\}

Desborough M [per comm]. Blood loss in infants and children for open heart operations: albumin 5\% versus fresh-frozen plasma in the prime. Email to oliver.william@mayo.edu for further information 11 December 2014 Reply with information on number of patients who underwent any transfusion on 16 January 2015.

* Oliver WC Jr, Beynen FM, Nuttall GA, Schroeder DR, Ereth $\mathrm{MH}$, Dearani JA, et al. Blood loss in infants and children for open heart operations: albumin 5\% versus fresh-frozen plasma in the prime. Annals of Thoracic Surgery 2003;75(5):1506-12.

Snow 1982 \{published data only\}

Snow N, Lucas AE. Prophylactic fresh frozen plasma administration: failure to reduce blood loss or transfusion requirements after routine cardiopulmonary bypass. Journal of Extra-Corporeal Technology 1982;14(4):400-4.

Trimble 1964 \{published data only\} Trimble AS, Osborn JJ, Kerth WJ, Gerbode F. The prophylactic use of fresh frozen plasma after extracorporeal circulation. Journal of Thoracic and Cardiovascular Surgery 1964;48(2):314-6.

Tølløfsrud 2003 \{published data only\} Desborough M [per comm]. Universal solvent/detergenttreated fresh frozen plasma (Uniplas--rationale and clinical properties). Email to bjarte.solheim@rikshospitalet.no for further information 11 December 2014 Email address no longer in use.

Noddeland H, Töllöfsrud S, Svennevig J, Bentsen G, Brosstad F, Solheim B. Universal solvent/detergenttreated fresh frozen plasma (Uniplas--rationale and clinical properties). Thrombosis Research 2002;107(Suppl 1):S33-7. * Tølløfsrud S, Noddeland H, Svennevig JL, Bentsen G, Mollnes TE, Solheim BG. Universal fresh frozen plasma (Uniplas): a safe product in open-heart surgery. Intensive Care Medicine 2003;29(10):1736-43.

Wilhelmi 2001 \{published data only\}

Wilhelmi M, Franke U, Cohnert T, Weber P, Kaukemüller $\mathrm{J}$, Fischer $\mathrm{S}$, et al. Coronary artery bypass grafting surgery 
without the routine application of blood products: is it feasible?. European Journal of Cardiothoracic Surgery 2001; 19(5):657-61.

\section{References to studies excluded from this review}

Armellin 2001 \{published data only\}

Armellin G, Sorbara C, Bonato R, Pittarello D, Dal Cero P, Giron G. Intraoperative plasmapheresis in cardiac surgery. Journal of Cardiothoracic and Vascular Anesthesia 1997;11 (1):13-7.

Bilgin 2011 \{published data only\}

Bilgin YM, van de Watering LM, Versteegh MI, van Oers MH, Vamvakas EC, Brand A. Postoperative complications associated with transfusion of platelets and plasma in cardiac surgery. Transfusion 2011;51(12):2603-10.

Boldt 1989 \{published and unpublished data\}

Boldt J, Kling D, von Bormann M, Zuge M, Hempelmann G. Homologes Frischplasma in der Herzchirurgie. Anaesthesist 1989;38:53-9.

Boldt 1990 \{published data only\}

Boldt J, VonBormann B, Kling D, Jacobi M, Moosdorf R, Hempelmann G. Preoperative plasmapheresis in patients undergoing cardiac surgery procedures. Anesthesiology 1990; 72(2):282-8.

Boldt 1993 \{published data only\}

Boldt J, Zickmann B, Ballesteros M, Oehmke S, Stertmann F, Hempelmann G. Influence of acute preoperative plasmapheresis on platelet function in cardiac surgery. Journal of Cardiothoracic and Vascular Anesthesia 1993;7(1): 4-9.

Chapanduka 2002 \{published data only\}

Chapanduka ZC, Fernandes-Costa FJTD, Rochat C, Blyth DF. Comparative safety and efficacy of Bioplasma FDP versus single-donor fresh-dried plasma in cardiopulmonary bypass patients. South African Medical Journal 2002;92(5): 356-7.

Demeyere 2010 \{published data only\}

Demeyere R, Arnout J, Strengers P. Prothrombin complex concentrate versus fresh frozen plasma in patients on oral anticoagulant therapy undergoing cardiac surgery: a randomized study. Critical Care. 2006; Vol. 10 (Suppl 1): P233.

* Demeyere R, Gillardin S, Arnout J, Strengers PF. Comparison of fresh frozen plasma and prothrombin complex concentrate for the reversal of oral anticoagulants in patients undergoing cardiopulmonary bypass surgery: a randomized study. Vox Sanguinis 2010;99(3):251-60.

Frenzel 2008 \{published and unpublished data\}

Frenzel W. Study of OCTAPLEX and FFP in patients under Vitamin K therapy antagonist needing urgent surgery or invasive procedures. https://clinicaltrials.gov/ct2/show/ NCT00618098 2008. [: NCT00618098]

Haubelt 2002 \{published data only\}

Haubelt H, Blome M, Kiessling AH, Isgro F, Bach J, Saggau W, et al. Effects of solvent/detergent-treated plasma and fresh-frozen plasma on haemostasis and fibrinolysis in complex coagulopathy following open-heart surgery. Vox Sanguinis 2002;82:9-14.

Hertfelder 1992 \{published data only\}

Hertfelder HJ, Papov-Cenic S, Urban A, Dusterwald M, Brecher AM. Activation of hemostasis by transfusions of whole blood or blood components in open heart surgery of children. Annals of Hematology. 1992; Vol. 64:A32.

Lancé 2012 \{published data only\}

Lance MD, Ninivaggi M, Schols SEM, Feijge MAH, Oehrl SK, Kuiper GJAJM, et al. Perioperative dilutional coagulopathy treated with fresh frozen plasma and fibrinogen concentrate: a prospective randomized intervention trial. Vox Sanguinis 2012;103(1):25-34.

Menges 2006 \{published data only\}

Menges T, Wagner RM, Welters I, Ruwoldt R, Boldt J, Hempelmann G. The role of the protein C-thrombomodulin system and fibrinolysis during cardiovascular surgery: influence of acute preoperative plasmapheresis. Journal of Cardiothoracic and Vascular Anesthesia 1996;10(4):482-9.

Safwat 2002 \{published data only\}

Safwat AM, Bush R, Prevec W, Reitan JA. Intraoperative use of platelet-plasmapheresis in vascular surgery. Journal of Clinical Anesthesia 2002;14(1):10-4.

von Sommoggy 1990 \{published data only\} von Sommoggly S, Fraunhofer J, Jelen-Esselborn S, Stemberger A. Coagulation changes during aortofemoral bifurcation bypass operations: is plasma substitution possible with hydroxyethyl starch (HES) only? [Gerinnungsveränderungen bei aortofemoralem Bifurkationsbypass: ist eine Volumen- und Plasmasubstitution mit Hydroxyäthylstärke allein möglich? ]. Anaesthesist 1990;39:353-60.

Yiu 2006 \{published data only\}

Yiu K, Siu C, Jim M, Tse H, Fan K, Chau M, et al. Comparison of the efficacy and safety profiles of intravenous vitamin $\mathrm{K}$ and fresh frozen plasma as treatment of warfarinrelated over-anticoagulation in patients with mechanical heart valves. American Journal of Cardiology 2006;97(3): 409-11.

\section{References to studies awaiting assessment}

Miao 2014 \{published data only\}

Miao X, Liu J, Zhao M, Cui Y, Feng Z, Zhao J, et al. The influence of cardiopulmonary bypass priming without FFP on postoperative coagulation and recovery in pediatric patients with cyanotic congenital heart disease. European Journal of Paediatrics 2014;173(11):1437-43.

Miao 2015 \{published data only\}

Liu J, Feng Z, Zhao J, Miao X, Long C. The impact of priming without plasma during cardiopulmonary bypass on postoperative coagulation and clinical recovery in infants underwent cardiac surgery. Cardiology (Switzerland). 2014; Vol. 129:112-3.

* Miao X, Liu J, Zhao M, Cui Y, Feng Z, Zhao J, et al. Evidence-based use of FFP: the influence of a priming 
strategy without FFP during $\mathrm{CPB}$ on postoperative coagulation and recovery in pediatric patients. Perfusion 2015;30(2):140-7.

\section{References to ongoing studies}

\section{ACTRN12613001279718 \{published data only\}}

Prothrombinex-VF vs fresh frozen plasma for the treatment of bleeding post-cardiopulmonary bypass. https:// www.anzctr.org.au/Trial/Registration/TrialReview.aspx?id= 365300. [: ACTRN12613001279718]

EudraCT: 2009-016709-41 \{published data only\} Coagulopathy during surgery for the repair of extent 4 thoraco-abdominal aortic aneurysms - feasibility study of the use of fibrinogen concentrate by infusion in place of fresh frozen plasma. https://www.clinicaltrialsregister.eu/ ctr-search/search?query=2009-016709-41 . [: 2009_ 016709-41]

EudraCT: 2014-000452-28 \{published data only\} Vasculopathic Injury and Plasma as Endothelial Rescue - OCTAplas Trial (VIPER-OCTA). https:// www.clinicaltrialsregister.eu/ctr-search/search?query $=2014$ 000452-28. [: 2014-000452-28]

\section{Additional references}

\section{Andrzejewski 2005}

Andrzejewski C, Popovsky MA. Transfusion-associated adverse pulmonary sequelae: widening our perspective. Transfusion 2005;45(7):1048-50.

\section{BCSH Guidelines 2004}

O'Shaughnessy DF, Atterbury C, Bolton Maggs P, Murphy $\mathrm{M}$, Thomas D, Yates S, et al. Guidelines for the use of freshfrozen plasma, cryoprecipitate and cryosupernatant. British Journal of Haematology 2004;126(1):11-28.

\section{Bevan 1999}

Bevan DH. Cardiac bypass haemostasis: putting blood through the mill. British Journal of Haematology 1999;104 (2):208-19.

Bjursten 2013

Bjursten H, Dardashti A, Ederoth P, Brondén B, Algotsson L. Increased long-term mortality with plasma transfusion after coronary artery bypass surgery. Intensive Care Medicine 2013;39(3):437-44.

\section{Boccia 2009}

Boccia S. PRISMA: an attempt to improve standards for reporting systematic review and meta-analysis. Journal of Public Health 2009;6(4):352-3.

CMA Guidelines 1997

Canadian Medical Association Expert Working Group. Guidelines for red blood cell and plasma transfusion for adults and children. Canadian Medical Association Journal 1997;156(11 Suppl):S1-S24.

\section{Davidson 2014}

Davidson S. State of the art: how I manage coagulopathy in cardiac surgery patients. British Journal of Haematology 2014;164(6):779-89.

\section{Desborough 2012}

Desborough M, Stanworth S. Plasma transfusion for bedside, radiologically guided, and operating room invasive procedures. Transfusion 2012;52(Suppl 1):20S-9S.

\section{Doussau 2014}

Doussau A, Perez P, Puntous M, Calderon J, Jeanne $\mathrm{M}$, Germain C, et al. Fresh-frozen plasma transfusion did not reduce 30-day mortality in patients undergoing cardiopulmonary bypass cardiac surgery with excessive bleeding: the PLASMACARD multicenter cohort study. Transfusion 2014;54(4):1114-24.

\section{GRADEpro 2014}

McMaster University. GRADEpro [Computer program on www.gradepro.org]. Version [3rd June 2015]. McMaster University, 2014.

\section{Hartmann 2006}

Hartmann M, Sucker C, Boehm O, Koch A, Loer S, Zacharowski K. Effects of cardiac surgery on hemostasis. Transfusion Medicine Reviews 2006;20(3):230-41.

\section{Higgins 2011a}

Higgins JPT, Altman DG, Sterne JAC (editors). Chapter 8: Assessing risk of bias in included studies. In: Higgins JPT, Green S (editors). Cochrane Handbook for Systematic Reviews of Interventions Version 5.1.0 [updated March 2011]. The Cochrane Collaboration, 2011. Available from www.cochrane-handbook.org.

\section{Higgins 2011b}

Higgins JPT, Deeks JJ (editors). Chapter 7: Selecting studies and collecting data. In: Higgins JPT, Green S (editors). Cochrane Handbook for Systematic Reviews of Interventions Version 5.1.0 [updated March 2011]. The Cochrane Collaboration, 2011. Available from www.cochrane-handbook.org.

\section{Juni 2001}

Juni P, Altman DG, Egger M. Systematic reviews in health care: assessing the quality of controlled clinical trials. $B M J$ 2001;323(7303):42-6.

Khan 2007

Khan H, Belsher J, Yilmaz M, Afessa B, Winters JL, Moore $\mathrm{SB}$, et al. Fresh-frozen plasma and platelet transfusions are associated with development of acute lung injury in critically ill medical patients. Chest 2007;131(5):1308-14.

\section{Langendam 2013}

Langendam MW, Akl EA, Dahm P, Glasziou P, Guyatt G, Schünemann HJ. Assessing and presenting summaries of evidence in Cochrane Reviews. Systematic Reviews 2013;2: 81

\section{Lundberg 1994}

Lundberg GD. Practice parameter for the use of freshfrozen plasma, cryoprecipitate, and platelets. Fresh-frozen Plasma, Cryoprecipitate, and Platelets Administration Practice Guidelines Development Task Force of the College of American Pathologists. JAMA 1994;271(10):777-81. 


\section{MacLennan 2006}

MacLennan S, Williamson LM. Risks of fresh frozen plasma and platelets. Journal of Trauma 2006;60(6 Suppl):S46-50.

Narick 2012

Narick C, Triulzi DJ, Yazer MH. Transfusion-associated circulatory overload after plasma transfusion. Transfusion 2012;52(1):160-5.

Palo 2006

Palo R, Capraro L, Hovilehto S, Koivuranta M, Krusius T, Loponen E, et al. Population-based audit of fresh-frozen plasma transfusion practices. Transfusion 2006;46(11): 1921-5.

Pamphilon 2000

Pamphilon D. Viral inactivation of fresh frozen plasma. British Journal of Haematology 2000;109(4):680-93.

Pelletier 2006

Pelletier JPR, Transue S, Snyder EL. Pathogen inactivation techniques. Best Practice \& Research Clinical Haematology 2006;19(1):205-42.

RevMan 2014

The Nordic Cochrane Centre, The Cochrane Collaboration. Review Manager (RevMan). 5.3. Copenhagen: The Nordic Cochrane Centre, The Cochrane Collaboration, 2014

Roseff 2002

Roseff SD, Luban NL, Manno CS. Guidelines for assessing appropriateness of pediatric transfusion. Transfusion 2002; 42(11):1398-413.

SHOT 2014

Serious Hazards of Transfusion Steering Group. Annual SHOT Report 2013. Available at http://www.shotuk.org (accessed 28 April 2015) 2014.

Skeate 2007

Skeate RC, Eastlund T. Distinguishing between transfusion related acute lung injury and transfusion associated circulatory overload. Current Opinion in Hematology 2007; 14(6):682-7.

\section{Stanworth 2011}

Stanworth SJ, Grant-Casey J, Lowe D, Laffan M, New $\mathrm{H}$, Murphy MF, et al. The use of fresh-frozen plasma in England: high levels of inappropriate use in adults and children. Transfusion 2011;51(1):62-70.

\section{Vlaar 2013}

Vlaar AP, Juffermans NP. Transfusion-related acute lung injury: a clinical review. Lancet 2013;382(9896):984-94.

Vuylsteke 2011

Vuylsteke A, Pagel C, Gerrard C, Reddy B, Nashef S, Aldam P, et al. The Papworth Bleeding Risk Score: a stratification scheme for identifying cardiac surgery patients at risk of excessive early postoperative bleeding. European Journal of Cardiothoracic Surgery 2011;39(6):924-30.

Wallis 2004

Wallis JP, Dzik S. Is fresh frozen plasma overtransfused in the United States?. Transfusion 2004;44(11):1674-5.

Wise 2013

Wise J. Boldt: the great pretender. BMJ 2013;346:f1738.

Yang 2012

Yang L, Stanworth S, Hopewell S, Doree C, Murphy M. Is fresh-frozen plasma clinically effective? An update of a systematic review of randomized controlled trials. Transfusion 2012;52(8):1673-86.

\section{References to other published versions of this review}

\section{Wood 2009}

Wood EM, Stanworth S, Doree C, Hyde C, Silvani CM, Montedori A, Abraha I. Fresh frozen plasma for cardiovascular surgery. Cochrane Database of Systematic Reviews 2009, Issue 1. [DOI: 10.1002/ 14651858.CD007614]

* Indicates the major publication for the study 


\section{CHARACTERISTICS OF STUDIES}

\section{Characteristics of included studies [ordered by study ID]}

\section{Chong Sung 2006}

Methods

\begin{tabular}{|c|c|}
\hline & $\begin{array}{l}\text { Country: South Korea } \\
\text { Dates of trial (start and end): June } 2003 \text { to January } 2004 \\
\text { Follow-up until: } 24 \text { hours postoperatively }\end{array}$ \\
\hline Participants & $\begin{array}{l}\text { Inclusions: } \\
\text { 1. Children ( } 6 \text { months to } 10 \text { years) undergoing elective cardiac surgery with } \mathrm{CPB} \\
\text { Exclusions: } \\
\text { 1. Renal failure } \\
\text { 2. Abnormal pre-operative clotting parameters } \\
\text { 3. Infants ( } 6 \text { months) undergoing cardiac surgery } \\
\text { Age: } \\
\text { Intervention arm: median } 24 \text { months (range } 6 \text { to } 120 \text { months) } \\
\text { Comparator arm: median } 24 \text { months (range } 6 \text { to } 72 \text { months) } \\
\text { Ethnicity: } \\
\text { Not reported } \\
\text { Gender: } \\
\text { Not reported } \\
\text { Operations: } \\
\text { Intervention arm: elective surgery only; } 21 \text { non-cyanotic heart disease and } 0 \text { cyanotic } \\
\text { heart disease } \\
\text { Comparator arm: elective surgery only; } 19 \text { non-cyanotic heart disease and } 2 \text { cyanotic } \\
\text { heart disease }\end{array}$ \\
\hline Interventions & $\begin{array}{l}\text { Intervention arm: } \\
\text { Transfusion of } 10 \mathrm{ml} / \mathrm{kg} \text { FFP after CPB and heparin neutralisation }(\mathrm{n}=21) \\
\text { Comparator arm: } \\
\text { Infusion of } 10 \mathrm{ml} / \mathrm{kg} \text { hydroxyethyl starch (HES) } 130 / 0.4 \text { after CPB and heparin neu- } \\
\text { tralisation) }(\mathrm{n}=21)\end{array}$ \\
\hline Outcomes & $\begin{array}{l}\text { Primary: } \\
\text { Blood loss at } 24 \text { hours postoperatively } \\
\text { Other outcomes: } \\
\text { 1. Red cell transfusion requirements } 24 \text { hours postoperatively } \\
\text { 2. INR immediately after transfusion of FFP or HES and at } 24 \text { hours postoperatively } \\
\text { 3. APTT immediately after transfusion of FFP or HES and at } 24 \text { hours postoperatively } \\
\text { 4. Haematocrit immediately after transfusion of FFP or HES } \\
\text { 5. Return to theatre within } 24 \text { hours postoperatively } \\
\text { 6. Mortality (time period not stated) }\end{array}$ \\
\hline Notes & - \\
\hline
\end{tabular}

Type of study: single-centre, parallel-group randomised controlled trial. Full-text paper Country: South Korea

Dates of trial (start and end): June 2003 to January 2004

Follow-up until: 24 hours postoperatively

1. Children (6 months to 10 years) undergoing elective cardiac surgery with $\mathrm{CPB}$

Exclusions:

. Renal failure

2. Abnormal pre-operative clotting parameters

Comparator arm: median 24 months (range 6 to 72 months)

Ethnicity:

Not reported

nder:

Intervention arm: elective surgery only; 21 non-cyanotic heart disease and 0 cyanotic heart disease

Comparator arm: elective surgery only; 19 non-cyanotic heart disease and 2 cyanotic

Transfusion of $10 \mathrm{ml} / \mathrm{kg}$ FFP after CPB and heparin neutralisation $(\mathrm{n}=21)$

Comparator arm:

Infusion of $10 \mathrm{ml} / \mathrm{kg}$ hydroxyethyl starch (HES) 130/0.4 after CPB and heparin neutralisation) $(\mathrm{n}=21)$

Other outcomes:

1. Red cell transfusion requirements 24 hours postoperatively

2. INR immediately after transfusion of FFP or HES and at 24 hours postoperatively

3. APTT immediately after transfusion of FFP or HES and at 24 hours postoperatively

4. Haematocrit immediately after transfusion of FFP or HES

5. Return to theatre within 24 hours postoperatively

6. Mortality (time period not stated)

\section{Risk of bias}




\begin{tabular}{|c|c|c|}
\hline Bias & Authors' judgement & Support for judgement \\
\hline $\begin{array}{l}\text { Random sequence generation (selection } \\
\text { bias) }\end{array}$ & Unclear risk & $\begin{array}{l}\text { Quote: "Study subjects received either } \\
10 \mathrm{~mL} / \mathrm{kg} \text { FFP ...or HES ...in a random } \\
\text { manner shortly after protamine infusion." } \\
\text { How the random sequence was generated } \\
\text { is not described }\end{array}$ \\
\hline Allocation concealment (selection bias) & Unclear risk & $\begin{array}{l}\text { Insufficient information about allocation } \\
\text { concealment to permit judgement }\end{array}$ \\
\hline Blinding of participants & Unclear risk & $\begin{array}{l}\text { Insufficient information about blinding of } \\
\text { participants to permit judgement }\end{array}$ \\
\hline Blinding of personnel & Unclear risk & $\begin{array}{l}\text { Insufficient information about blinding of } \\
\text { personnel to permit judgement }\end{array}$ \\
\hline $\begin{array}{l}\text { Blinding of outcome assessment (detection } \\
\text { bias) } \\
\text { All outcomes }\end{array}$ & Unclear risk & $\begin{array}{l}\text { Insufficient information about blinding of } \\
\text { analysts to permit judgement }\end{array}$ \\
\hline $\begin{array}{l}\text { Incomplete outcome data (attrition bias) } \\
\text { All outcomes }\end{array}$ & Low risk & All patients analysed \\
\hline Selective reporting (reporting bias) & Low risk & All pre-reported outcomes analysed \\
\hline Equal use of co-interventions in each arm & High risk & $\begin{array}{l}\text { Similar numbers of patients undergoing } \\
\text { each type of surgery. In addition to the } \\
\text { study intervention, patients in the control } \\
\text { group were given } 7.3 \pm 10.2 \mathrm{ml} / \mathrm{kg} \text { FFP } \\
\text { whereas those in the FFP group received an } \\
\text { additional } 3.8 \pm 7.1 \mathrm{ml} / \mathrm{kg} \text { FFP. This may } \\
\text { confound the outcomes }\end{array}$ \\
\hline Balance of baseline factors & Low risk & $\begin{array}{l}\text { Similar age groups and body weight of par- } \\
\text { ticipants }\end{array}$ \\
\hline
\end{tabular}

Consten 1996

Methods

Participants
Type of study: single-centre, parallel-group randomised controlled trial. Full-text paper Country: Netherlands

Dates of trial (start and end): not reported

Follow-up until: 5 days postoperatively

Inclusions:

1. Adults undergoing elective coronary artery bypass graft surgery with $\mathrm{CPB}$

Exclusions:

1. Abnormal pre-operative clotting parameters 


\begin{tabular}{|c|c|}
\hline & $\begin{array}{l}\text { 2. Left ventricular ejection fraction less than } 40 \% \\
\text { 3. Re-operations } \\
\text { 4. Cardiopulmonary bypass time exceeding } 2 \text { hours } \\
\text { 5. Valve replacement surgery } \\
\text { Age: } \\
\text { Intervention arm: median } 62 \text { years (range } 46 \text { to } 75 \text { years) } \\
\text { Comparator arm: median } 63 \text { years (range } 49 \text { to } 75 \text { years) } \\
\text { Ethnicity: } \\
\text { Not reported } \\
\text { Gender: } \\
\text { Intervention arm: } 20 \text { male and } 4 \text { female } \\
\text { Comparator arm: } 15 \text { male and } 11 \text { female } \\
\text { Operations: } \\
\text { Elective surgery only. All patients underwent coronary artery bypass graft with cardiopul- } \\
\text { monary bypass }\end{array}$ \\
\hline Interventions & $\begin{array}{l}\text { Intervention arm: } \\
\text { Postoperative transfusion of } 3 \text { units FFP }(\mathrm{n}=24) \\
\text { Comparator arm: } \\
\text { Postoperative infusion of gelofusine } 750 \mathrm{ml}(\mathrm{n}=26)\end{array}$ \\
\hline Outcomes & $\begin{array}{l}\text { Primary: } \\
\text { Not reported } \\
\text { Other outcomes: } \\
\text { 1. Blood loss at up to } 6 \text { days postoperatively } \\
\text { 2. Transfusion requirements at up to } 6 \text { days postoperatively } \\
\text { 3. Prothrombin time immediately postoperatively and at } 2 \text { hours, } 6 \text { hours, } 24 \text { hours and } \\
5 \text { days postoperatively } \\
\text { 4. Activated partial thromboplastin time immediately postoperatively and at } 2 \text { hours, } 6 \\
\text { hours, } 24 \text { hours and } 5 \text { days postoperatively }\end{array}$ \\
\hline Notes & - \\
\hline
\end{tabular}

\section{Risk of bias}

\begin{tabular}{l|l|l}
\hline Bias & Authors' judgement & Support for judgement \\
\hline $\begin{array}{l}\text { Random sequence generation (selection } \\
\text { bias) }\end{array}$ & Unclear risk & $\begin{array}{l}\text { Insufficient information about the se- } \\
\text { quence generation process to permit judge- } \\
\text { ment }\end{array}$ \\
\hline Allocation concealment (selection bias) & Unclear risk & $\begin{array}{l}\text { Quote: "randomisation envelope opened at } \\
\text { end of surgical procedure" }\end{array}$ \\
\hline Blinding of participants & Low risk & $\begin{array}{l}\text { Randomisation performed postoperatively. } \\
\text { Patients would not be aware of randomi- } \\
\text { sation and it would not affect outcomes if } \\
\text { they did }\end{array}$
\end{tabular}




\section{Consten 1996 (Continued)}

\begin{tabular}{|c|c|c|}
\hline Blinding of personnel & Low risk & $\begin{array}{l}\text { Quote: "Blinding was ensured by use of } \\
\text { two independent investigators, one in the } \\
\text { operating room and one in the intensive } \\
\text { care unit (ICU) and on the ward. The latter } \\
\text { was unaware of whether FFP or Gelofusine } \\
\text { plasma substitute had been administered." }\end{array}$ \\
\hline $\begin{array}{l}\text { Blinding of outcome assessment (detection } \\
\text { bias) } \\
\text { All outcomes }\end{array}$ & Unclear risk & $\begin{array}{l}\text { Insufficient information about blinding of } \\
\text { analysts to permit judgement }\end{array}$ \\
\hline $\begin{array}{l}\text { Incomplete outcome data (attrition bias) } \\
\text { All outcomes }\end{array}$ & Low risk & $\begin{array}{l}\text { Results as presented do not state how many } \\
\text { patients completed study but no patients } \\
\text { are described as not completing the study }\end{array}$ \\
\hline Selective reporting (reporting bias) & Low risk & All pre-reported outcomes analysed \\
\hline Equal use of co-interventions in each arm & Low risk & $\begin{array}{l}\text { Similar interventions in both groups. } \\
\text { Quote: "no patient in group } 2 \text { received } \\
\text { FFP" }\end{array}$ \\
\hline Balance of baseline factors & Low risk & $\begin{array}{l}\text { Similar mean age and gender. No informa- } \\
\text { tion on comorbidities }\end{array}$ \\
\hline
\end{tabular}

\section{Kanbak 2011}

Methods

Participants
Type of study: single-centre, parallel-group randomised controlled trial. Full-text paper Country: Turkey

Dates of trial (start and end): not reported

Follow-up until: 24 hours postoperatively

Inclusions:

1. Adults undergoing elective coronary artery bypass graft surgery with $\mathrm{CPB}$

Exclusions:

1. Abnormal pre-operative coagulation tests

2. Infective thrombus or ventricular aneurysm

3. Congenital antithrombin III deficiency

4. Pre-operative use of heparin, nitroglycerine, oral contraceptive pill or antiplatelet agents

5. Creatinine greater than $300 \mu \mathrm{g} / \mathrm{l}$

6. Clinical or laboratory evidence of liver dysfunction

7. $20 \%$ decrease in systolic blood pressure following nitroglycerine administration Age:

Intervention arm: mean 53.19 years (standard deviation 10.88 years)

Comparator arm 1: mean 58.81 years (standard deviation 8.26 years)

Comparator arm 2: mean 60.19 years (standard deviation 11.02 years)

Ethnicity:

Not reported 
Kanbak 2011 (Continued)

Gender:

Intervention arm: 13 male and 3 female

Comparator arm 1: 13 male and 3 female

Comparator arm 2: 12 male and 4 female

Operations:

Elective surgery only. All patients underwent coronary artery bypass graft with cardiopulmonary bypass

Interventions

Intervention arm:

Transfusion of $400 \mathrm{ml}$ (2 units) FFP after anaesthetic induction $(\mathrm{n}=16)$

Comparator arm 1:

No additional treatment $(\mathrm{n}=16)$

Comparator arm 2:

Infusion of 1000 units antithrombin III after anaesthetic induction $(\mathrm{n}=16)$

Outcomes

Primary:

Not reported

Other outcomes:

1. Activated clotting time after anaesthetic induction, before sternotomy, before heparin administration, 5 minutes after heparin administration, at the beginning of $\mathrm{CPB}$, after 30 minutes of $\mathrm{CPB}, 5$ minutes after the end of $\mathrm{CPB}$ and heparin neutralisation, and at the end of the operation

2. Prothrombin time after anaesthetic induction, 5 minutes after heparin administration, at the beginning of $\mathrm{CPB}$, after 30 minutes of $\mathrm{CPB}, 5$ minutes after the end of $\mathrm{CPB}$ and heparin neutralisation, and at the end of the operation

3. Thrombin time after anaesthetic induction, 5 minutes after heparin administration, at the beginning of $\mathrm{CPB}$, after 30 minutes of $\mathrm{CPB}, 5$ minutes after the end of $\mathrm{CPB}$ and heparin neutralisation, and at the end of the operation

4. Activated partial thromboplastin time after anaesthetic induction, 5 minutes after heparin administration, at the beginning of $\mathrm{CPB}$, after 30 minutes of $\mathrm{CPB}, 5$ minutes after the end of $\mathrm{CPB}$ and heparin neutralisation, and at the end of the operation

5. Antithrombin II activity after anaesthetic induction, 5 minutes after heparin administration, at the beginning of $\mathrm{CPB}$, after 30 minutes of $\mathrm{CPB}, 5$ minutes after the end of $\mathrm{CPB}$ and heparin neutralisation, and at the end of the operation

6. D-dimer after anaesthetic induction, 5 minutes after heparin administration, at the beginning of $\mathrm{CPB}$, after 30 minutes of $\mathrm{CPB}, 5$ minutes after the end of $\mathrm{CPB}$ and heparin neutralisation, and at the end of the operation

7. Blood loss postoperatively

8. Blood transfusion requirements postoperatively and after 24 hours

9. Heparin sensitivity

10. Total heparin requirements

11. Heparin consumption

12. Heparin sensitivity

13. Time in operating theatre

14. Urine output postoperatively and after 24 hours group. Both groups received additional FFP during the operations and postoperatively 
Kanbak 2011 (Continued)

\section{Risk of bias}

\begin{tabular}{|c|c|c|}
\hline Bias & Authors' judgement & Support for judgement \\
\hline $\begin{array}{l}\text { Random sequence generation (selection } \\
\text { bias) }\end{array}$ & Unclear risk & $\begin{array}{l}\text { Quote: "The patients were allocated in a } \\
\text { randomised fashion into three groups of } 16 \\
\text { each" }\end{array}$ \\
\hline Allocation concealment (selection bias) & Unclear risk & $\begin{array}{l}\text { Insufficient information about allocation } \\
\text { concealment to permit judgement }\end{array}$ \\
\hline Blinding of participants & Unclear risk & $\begin{array}{l}\text { Insufficient information about blinding of } \\
\text { participants to permit judgement }\end{array}$ \\
\hline Blinding of personnel & High risk & $\begin{array}{l}\text { Personnel transfused FFP or antithrombin } \\
\text { III post-induction to those randomised to } \\
\text { the FFP or antithrombin groups and, con- } \\
\text { sequently, they will not have been blinded } \\
\text { to the intervention }\end{array}$ \\
\hline $\begin{array}{l}\text { Blinding of outcome assessment (detection } \\
\text { bias) } \\
\text { All outcomes }\end{array}$ & Unclear risk & $\begin{array}{l}\text { Insufficient information about blinding of } \\
\text { analysts to permit judgement }\end{array}$ \\
\hline $\begin{array}{l}\text { Incomplete outcome data (attrition bias) } \\
\text { All outcomes }\end{array}$ & Low risk & $\begin{array}{l}\text { Results as presented do not state how many } \\
\text { patients completed study but no patients } \\
\text { are described as not completing the study }\end{array}$ \\
\hline Selective reporting (reporting bias) & Low risk & All pre-reported outcomes analysed \\
\hline Equal use of co-interventions in each arm & High risk & $\begin{array}{l}\text { Similar interventions in both groups. All } \\
\text { patients were given additional FFP with a } \\
\text { mean volume of } 1219 \mathrm{ml} \text { in the FFP group; } \\
1218 \mathrm{ml} \text { in antithrombin III group; and } \\
737 \mathrm{ml} \text { in the control group. This may con- } \\
\text { found the outcomes }\end{array}$ \\
\hline Balance of baseline factors & Low risk & $\begin{array}{l}\text { Similar mean age and gender. No informa- } \\
\text { tion on comorbidities }\end{array}$ \\
\hline
\end{tabular}


Methods

Participants
Type of study: single-centre, parallel-group randomised controlled trial. Full-text paper Country: Germany

Dates of trial (start and end): not reported

Follow-up until: 5 days postoperatively

Inclusions:

1. Adults undergoing elective coronary artery bypass graft surgery with $\mathrm{CPB}$

2. Weight $50 \mathrm{~kg}$ to $100 \mathrm{~kg}$

3. Met criteria for autologous blood donation

Exclusions:

1. Abnormal pre-operative clotting parameters

2. Left ventricular ejection fraction less than $40 \%$

3. Haemoglobin $<120 \mathrm{~g} / \mathrm{l}$

4. Plasma protein $<60 \mathrm{~g} / \mathrm{l}$

5. Concurrent medications known to affect blood coagulation

6. Creatinine $>1500 \mu \mathrm{mol} / \mathrm{l}$

7. Allergy to hydroxyethyl starch (HES)

Age:

Intervention arm: mean 58 years (standard deviation 7 years)

Comparator arm: mean 56 years (standard deviation 8 years)

Ethnicity:

Not reported

Gender:

Intervention arm: 24 male and 3 female

Comparator arm: 25 male and 4 female

Operations:

Elective surgery only. All patients underwent coronary artery bypass graft with cardiopulmonary bypass

Interventions

Intervention arm:

Transfusion of $15 \mathrm{ml} / \mathrm{kg}$ autologous FFP after CPB and heparin neutralisation $(\mathrm{n}=27)$ Comparator arm:

Infusion of $15 \mathrm{ml} / \mathrm{kg} 6 \%$ HES 450/0.7 after CPB and heparin neutralisation $(\mathrm{n}=29)$

Outcomes

Primary:

Blood loss at 12 hours and 24 hours postoperatively

Other outcomes:

1. Transfusion requirements 24 hours postoperatively

2. Prothrombin time immediately after transfusion of FFP or HES and at 24 hours, 3 days and 7 days postoperatively

3. Activated partial thromboplastin time immediately after transfusion of FFP or HES and at 24 hours, 3 days and 7 days postoperatively

4. Fibrinogen concentration immediately after transfusion of FFP or HES and at 24 hours, 3 days and 7 days postoperatively

5. Antithrombin III levels immediately after transfusion of FFP or HES and at 24 hours,

3 days and 7 days postoperatively

6 . Return to theatre within 5 days

7. Haematocrit 6 hours postoperatively 
Kasper 2001 (Continued)

\begin{tabular}{|c|c|c|}
\hline Notes & - & \\
\hline \multicolumn{3}{|l|}{ Risk of bias } \\
\hline Bias & Authors' judgement & Support for judgement \\
\hline $\begin{array}{l}\text { Random sequence generation (selection } \\
\text { bias) }\end{array}$ & Low risk & $\begin{array}{l}\text { Quote: "randomisation was based on a } \\
\text { computer-generated code that was pre- } \\
\text { pared by an individual not involved in the } \\
\text { study and was sealed in sequentially num- } \\
\text { bered opaque envelopes" }\end{array}$ \\
\hline Allocation concealment (selection bias) & High risk & $\begin{array}{l}\text { Comment: patients allocated to the FFP } \\
\text { group had autologous plasma collected by } \\
\text { apheresis on } 2 \text { occasions. Therefore, it is } \\
\text { possible that on generating the allocation } \\
\text { (e.g. to undergo apheresis collection, or } \\
\text { not) there was potential for the requirement } \\
\text { for the arrangements to be known }\end{array}$ \\
\hline Blinding of participants & High risk & $\begin{array}{l}\text { Quote: "Patients in the FFP group had a } \\
\text { total volume of } 15 \mathrm{ml} / \mathrm{kg} \text { of autologous, } \\
\text { platelet-poor plasma collected at two vis- } \\
\text { its during the preoperative period, which } \\
\text { was re infused intraoperatively after termi- } \\
\text { nation of CPB and heparin neutralization. } \\
\text { Patients in the HES group did not donate } \\
\text { autologous plasma before surgery" } \\
\text { Comment: it will have been clear to pa- } \\
\text { tients which group they were in by whether } \\
\text { they were invited to donate autologous } \\
\text { plasma pre-operatively, or not }\end{array}$ \\
\hline Blinding of personnel & High risk & $\begin{array}{l}\text { Quote: "The investigators were not blinded } \\
\text { to which substance was being administered. } \\
\text { " }\end{array}$ \\
\hline $\begin{array}{l}\text { Blinding of outcome assessment (detection } \\
\text { bias) } \\
\text { All outcomes }\end{array}$ & High risk & $\begin{array}{l}\text { Quote: "The investigators were not blinded } \\
\text { to which substance was being administered. } \\
\text { " }\end{array}$ \\
\hline $\begin{array}{l}\text { Incomplete outcome data (attrition bias) } \\
\text { All outcomes }\end{array}$ & Low risk & $\begin{array}{l}4 \text { patients (FFP group, } 3 \text { patients; HES } \\
\text { group, } 1 \text { patient) were excluded from anal- } \\
\text { ysis: } 1 \text { patient from each group developed } \\
\text { severe left ventricular failure during wean- } \\
\text { ing from CPB and required intra-aortic bal- } \\
\text { loon pumping; the infusion of a relatively } \\
\text { large quantity ( } 15 \mathrm{ml} / \mathrm{kg} \text { ) of fluid within a } \\
\text { short period of time was deemed inappro- }\end{array}$ \\
\hline
\end{tabular}

Fresh frozen plasma for cardiovascular surgery (Review) 
Kasper 2001 (Continued)

priate in these patients. Remaining patients were all included in final analysis

\begin{tabular}{l|ll}
\hline Selective reporting (reporting bias) & Low risk & All pre-reported outcomes analysed \\
\hline Equal use of co-interventions in each arm & High risk & $\begin{array}{l}3 \text { patients in the control group received } \\
\text { FFP. No patients in the FFP group received } \\
\text { additional FFP in addition to the interven- } \\
\text { tion. This may confound the outcomes }\end{array}$ \\
\hline Balance of baseline factors & Low risk & $\begin{array}{l}\text { Similar mean age, gender and weight. No } \\
\text { information on co-morbidities }\end{array}$ \\
\hline
\end{tabular}

Kyoung 2004

Methods

Type of study: single-centre, parallel-group randomised controlled trial. Full-text paper Country: South Korea

Dates of trial (start and end): not reported

Follow-up until: 24 hours postoperatively

Participants

Inclusions:

1. Children (age > 6 months, upper age limit not specified) undergoing cardiac surgery with $\mathrm{CPB}$

Exclusions:

1. Preoperative treatment with anticoagulant

2. Known coagulation disorder

Age:

Intervention arm: mean 37.5 months (standard deviation 32.2 months)

Comparator arm 1: mean 36.4 months (standard deviation 24.4 months)

Comparator arm 2: mean 19.1 months (standard deviation 17.0 months)

Ethnicity:

Not reported

Gender:

Intervention arm: 3 male and 7 female

Comparator arm 1: 6 male and 4 female

Comparator arm 2: 5 male and 5 female

Operations:

Intervention arm: elective surgery only; 10 non-cyanotic heart disease

Comparator arm 1: elective surgery only; 8 non cyanotic heart disease and 2 cyanotic heart disease

Comparator arm 2: elective surgery only; 9 non cyanotic heart disease and 1 cyanotic heart disease

Interventions

Intervention arm:

Transfusion of $10 \mathrm{ml} / \mathrm{kg}$ FFP after CPB and heparin neutralisation $(\mathrm{n}=10)$

Comparator arm 1:

Infusion of $10 \mathrm{ml} / \mathrm{kg}$ hydroxyethyl starch (HES) 130/0.4 after CPB and heparin neutralisation $(\mathrm{n}=10)$

Comparator arm 2: 
Infusion of $10 \mathrm{ml} / \mathrm{kg}$ HES 200/0.5 after CPB and heparin neutralisation ( $\mathrm{n}=10$ ). Details from this arm have not been used in the review as it was important not to use the intervention arm twice for comparisons

\begin{tabular}{ll} 
Outcomes & Primary: \\
& Not reported \\
Other outcomes: & 1. Blood loss 24 hours postoperatively \\
& 2. Haematocrit at end of surgery and 24 hours postoperatively \\
3. Activated partial thromboplastin time at end of surgery and 24 hours postoperatively & 4. INR at end of surgery and 24 hours postoperatively \\
& 5. Transfusion requirements 24 hours postoperatively \\
& 6. Changes in central venous pressure before, and after, FFP or HES infusion \\
& 7. Return to theatre during the study \\
\hline Notes & The trial is published in Korean and was translated into English \\
\hline
\end{tabular}

Risk of bias

\begin{tabular}{|c|c|c|}
\hline Bias & Authors' judgement & Support for judgement \\
\hline $\begin{array}{l}\text { Random sequence generation (selection } \\
\text { bias) }\end{array}$ & Unclear risk & $\begin{array}{l}\text { Insufficient information about the se- } \\
\text { quence generation process to permit judge- } \\
\text { ment }\end{array}$ \\
\hline Allocation concealment (selection bias) & Unclear risk & $\begin{array}{l}\text { Insufficient information about allocation } \\
\text { concealment to permit judgement }\end{array}$ \\
\hline Blinding of participants & Unclear risk & $\begin{array}{l}\text { Insufficient information about blinding of } \\
\text { participants to permit judgement }\end{array}$ \\
\hline Blinding of personnel & Unclear risk & $\begin{array}{l}\text { Insufficient information about blinding of } \\
\text { personnel to permit judgement }\end{array}$ \\
\hline $\begin{array}{l}\text { Blinding of outcome assessment (detection } \\
\text { bias) } \\
\text { All outcomes }\end{array}$ & Unclear risk & $\begin{array}{l}\text { Insufficient information about blinding of } \\
\text { analysts to permit judgement }\end{array}$ \\
\hline $\begin{array}{l}\text { Incomplete outcome data (attrition bias) } \\
\text { All outcomes }\end{array}$ & Low risk & $\begin{array}{l}\text { Results as presented do not state how many } \\
\text { patients completed study but no patients } \\
\text { are described as not completing the study }\end{array}$ \\
\hline Selective reporting (reporting bias) & Low risk & All pre-reported outcomes analysed \\
\hline Equal use of co-interventions in each arm & High risk & $\begin{array}{l}\text { In addition to the study intervention, pa- } \\
\text { tients in the HES } 130 / 0.4 \text { group were given } \\
7.3 \pm 10.2 \mathrm{ml} / \mathrm{kg} \mathrm{FFP} \text {; patients in the HES } \\
130 / 0.4 \text { group were given } 7.7 \pm 7.0 \mathrm{ml} / \mathrm{kg} \text {; } \\
\text { whereas those in the FFP group received an }\end{array}$ \\
\hline
\end{tabular}


Kyoung 2004 (Continued)

additional $3.8 \pm 7.1 \mathrm{ml} / \mathrm{kg}$ FFP. This may confound the outcomes

Lee 2013

Methods

Type of study: single-centre, parallel-group randomised controlled trial. Full-text paper Country: South Korea

Dates of trial (start and end): not reported

Follow-up until: 24 hours after postoperative ICU admission

Participants

Inclusions:

1. Infants (less than 12 months old) and children (1 to 16 years old) undergoing elective heart surgery with $\mathrm{CPB}$

Exclusions:

1. Neonates (less than 1 month of age)

2. Previously diagnosed coagulation disorder of non-cardiac origin

3. Metabolic disorder leading to abnormalities in plasma protein profiles

Patients could be excluded from the final analysis after randomisation:

1. Patients who were transferred to ICU with an open chest

2. Patients who returned to theatre within 24 hours due to postoperative bleeding

Children

Age:

Intervention arm: median 121 months (interquartile range 42.2 to 177.9 months)

Comparator arm: median 68 months (interquartile range 45.3 to 166 months)

Ethnicity:

Not reported

Gender:

Intervention arm: 19 male and 15 female

Comparator arm: 15 male and 18 female

Operations:

Intervention arm: elective surgery only; 27 non-cyanotic heart disease and 7 cyanotic heart disease

Comparator arm: elective surgery only; 21 non-cyanotic heart disease and 12 cyanotic heart disease

Infants

Age:

Intervention arm: median 3.6 months (interquartile range 2.1 to 6.8 months)

Comparator arm: median 2.6 months (interquartile range 1.5 to 3.7 months)

Ethnicity:

Not reported

Gender:

Intervention arm: 8 male and 18 female

Comparator arm: 15 male and 13 female

Operations:

Intervention arm: elective surgery only; 20 non-cyanotic heart disease and 6 cyanotic 


\begin{tabular}{|c|c|}
\hline & $\begin{array}{l}\text { heart disease } \\
\text { Comparator arm: elective surgery only; } 25 \text { non-cyanotic heart disease and } 3 \text { cyanotic } \\
\text { heart disease }\end{array}$ \\
\hline Interventions & $\begin{array}{l}\text { Children } \\
\text { Intervention arm: } \\
\text { Transfusion with } 1 \text { to } 2 \text { units FFP with CPB priming intra-operatively }(\mathrm{n}=34) \\
\text { Comparator arm: } \\
\text { Transfusion with } 50 \text { to } 100 \mathrm{ml} 20 \% \text { HAS with CPB priming intra-operatively }(\mathrm{n}=33) \\
\text { Infants } \\
\text { Intervention arm: } \\
\text { Transfusion with } 1 \text { to } 2 \text { units FFP with CPB priming intra-operatively }(\mathrm{n}=26) \\
\text { Comparator arm: } \\
\text { Transfusion with } 50 \text { to } 100 \mathrm{ml} 20 \% \text { HAS with CPB priming intra-operatively }(\mathrm{n}=28)\end{array}$ \\
\hline Outcomes & $\begin{array}{l}\text { Outcomes for infants and children reported separately } \\
\text { Primary: } \\
\text { Blood loss at } 24 \text { hours postoperatively } \\
\text { Other outcomes: } \\
\text { 1. Clauss fibrinogen post-CPB and heparin reversal and at } 24 \text { hours postoperatively } \\
\text { 2. Rotational thromboelastometry post-CPB and heparin reversal and at } 24 \text { hours post- } \\
\text { operatively } \\
\text { 3. Red cell transfusion requirements at } 24 \text { hours postoperatively } \\
\text { 4. Platelet transfusion requirements at } 24 \text { hours postoperatively } \\
\text { 5. Prothrombin time at } 24 \text { hours postoperatively } \\
\text { 6. Activated partial thromboplastin time at } 24 \text { hours postoperatively }\end{array}$ \\
\hline Notes & - \\
\hline
\end{tabular}

Risk of bias

\begin{tabular}{l|l|l}
\hline Bias & Authors' judgement & Support for judgement \\
\hline $\begin{array}{l}\text { Random sequence generation (selection } \\
\text { bias) }\end{array}$ & Unclear risk & $\begin{array}{l}\text { Insufficient information about random se- } \\
\text { quence generation to permit judgement }\end{array}$ \\
\hline Allocation concealment (selection bias) & Unclear risk & $\begin{array}{l}\text { Quote: "Using a sealed envelope method, } \\
\text { patients were randomly allocated into ei- } \\
\text { ther control or treatment groups" } \\
\text { Comment: does not state whether these } \\
\text { were serially numbered, sealed, opaque en- } \\
\text { velopes }\end{array}$ \\
\hline Blinding of participants & Unclear risk & $\begin{array}{l}\text { Insufficient information about blinding of } \\
\text { participants to permit judgement }\end{array}$ \\
\hline Blinding of personnel & Low risk & $\begin{array}{l}\text { Quote: "With the exception of perfusion- } \\
\text { ists, anaesthesiologists, surgeons, and per- } \\
\text { sonnel working in the ICU were all blinded }\end{array}$ \\
\hline
\end{tabular}


Lee 2013 (Continued)

to the designated group of a patient"

\begin{tabular}{|c|c|c|}
\hline $\begin{array}{l}\text { Blinding of outcome assessment (detection } \\
\text { bias) } \\
\text { All outcomes }\end{array}$ & Unclear risk & $\begin{array}{l}\text { Insufficient information about blinding of } \\
\text { analysts to permit judgement }\end{array}$ \\
\hline $\begin{array}{l}\text { Incomplete outcome data (attrition bias) } \\
\text { All outcomes }\end{array}$ & Low risk & $\begin{array}{l}1 \text { patient in each group was excluded from } \\
\text { final analysis as they required delayed ster- } \\
\text { nal closure for haemodynamic stability (a } \\
\text { pre-specified exclusion) }\end{array}$ \\
\hline Selective reporting (reporting bias) & Low risk & All pre-reported outcomes analysed \\
\hline Equal use of co-interventions in each arm & High risk & $\begin{array}{l}\text { Additional FFP could be given at the clini- } \\
\text { cians' discretion. Patients in the FFP group } \\
\text { received no additional FFP. Patients in the } \\
\text { control group received a median } 150 \mathrm{ml} \\
\text { FFP (interquartile range } 0 \text { to } 300 \mathrm{ml} \text { ). This } \\
\text { may confound the outcomes }\end{array}$ \\
\hline Balance of baseline factors & Low risk & $\begin{array}{l}\text { Similar age, weight, gender and surgical } \\
\text { procedures in both groups }\end{array}$ \\
\hline
\end{tabular}

Loeffelbein 2008

Methods

Type of study: single-centre, parallel-group randomised controlled trial. Full-text paper Country: Germany

Dates of trial (start and end): not reported

Follow-up until: 6 hours postoperatively

Participants

Inclusions:

1. Neonates and infants (age range not defined) undergoing open heart surgery with $\mathrm{CPB}$

2. Weight less than $6.5 \mathrm{~kg}$

3. Maximum cardiac output rate 1.1 litres per minute

Exclusions:

1. Metabolic disturbances (not defined)

2. Infections

3. Emergency surgery

Age:

Intervention arm: median 130 days (range 4 to 257 days)

Comparator arm: median 119 days (range 3 to 513 days)

Ethnicity:

Not reported

Gender:

Intervention arm: 6 male and 4 female

Comparator arm: 8 male and 2 female

Operations:

Fresh frozen plasma for cardiovascular surgery (Review)

Copyright @ 2015 The Cochrane Collaboration. Published by John Wiley \& Sons, Ltd. 
Loeffelbein 2008 (Continued)

Intervention arm: elective surgery only; 6 non-cyanotic heart disease and 4 cyanotic heart disease

Comparator arm: elective surgery only; 6 non-cyanotic heart disease and 4 cyanotic heart disease

Interventions

Intervention arm:

Transfusion of a mean of $23 \mathrm{ml} / \mathrm{kg}$ FFP with CPB priming intra-operatively $(\mathrm{n}=10)$

Comparator arm:

Transfusion of a mean of $8.8 \mathrm{ml} / \mathrm{kg}$ FFP and $16.9 \mathrm{ml} / \mathrm{kg} 20 \%$ HAS with CPB priming intra-operatively $(\mathrm{n}=10)$

Outcomes

Primary:

Body weight gain 6 hours postoperatively

Other outcomes:

1. Renal function 6 hours postoperatively

2. Renal protein loss 6 hours postoperatively

3. Inflammatory response (Interleukin-6, Interleukin-8, C-reactive protein and leukocyte count) 6 hours postoperatively

Notes

Patients in the FFP group received $122 \pm 13.2 \mathrm{ml} \mathrm{FFP}$ and no albumin. Patients in the albumin group received $100 \mathrm{ml}$ albumin and a variable amount of FFP $(52 \mathrm{ml} \pm 18.6$ $\mathrm{ml})$. See notes re bypass times and follow-up time below

Risk of bias

Bias

Random sequence generation (selection Unclear risk bias)
Authors' judgement

\section{Support for judgement}

Quote: "20 patients were allocated to this study" and "Blind randomisation was conducted by the Centre of Clinical Studies, University of Freiburg"

Comment: no additional information is supplied

\section{Allocation concealment (selection bias) Unclear risk}

Low risk

Unclear risk

Quote: "20 patients were allocated to this study" and "Blind randomisation was conducted by the Centre of Clinical Studies, University of Freiburg"

Comment: no additional information is supplied

Participants were neonates and infants and at this young age are likely to be unaware of their random allocation

Blinding of personnel
Insufficient information about blinding of personnel to permit judgement 
Loeffelbein 2008 (Continued)

\begin{tabular}{|c|c|c|}
\hline $\begin{array}{l}\text { Blinding of outcome assessment (detection } \\
\text { bias) } \\
\text { All outcomes }\end{array}$ & Unclear risk & $\begin{array}{l}\text { Insufficient information about blinding of } \\
\text { analysts to permit judgement }\end{array}$ \\
\hline $\begin{array}{l}\text { Incomplete outcome data (attrition bias) } \\
\text { All outcomes }\end{array}$ & Low risk & $\begin{array}{l}20 \text { patients allocated and all appeared to } \\
\text { complete the study, with data provided on } \\
\text { all predefined parameters. However, the } \\
\text { study reports only on the period up to } 6 \\
\text { hours after the end of bypass }\end{array}$ \\
\hline Selective reporting (reporting bias) & Low risk & All pre-reported outcomes analysed \\
\hline Equal use of co-interventions in each arm & High risk & $\begin{array}{l}\text { Comment: patients in the FFP group re- } \\
\text { ceived } 122 \pm 13.2 \mathrm{ml} \text { FFP and no albumin. } \\
\text { Patients in the albumin group received } 100 \\
\mathrm{ml} \text { albumin and a variable amount of FFP } \\
(52 \mathrm{ml} \pm 18.6 \mathrm{ml}) \text {. FFP received by the al- } \\
\text { bumin group may bias the results. Longer } \\
\mathrm{CPB} \text { time in the FFP group ( } 128 \text { minutes } \\
\text { in FFP group and } 87 \text { minutes in albumin } \\
\text { group) }\end{array}$ \\
\hline
\end{tabular}

Balance of baseline factors Low risk

Similar age, weight and gender in both groups

Långström 2008

Methods

Type of study: single-centre, parallel-group randomised controlled trial. Full-text paper Dates of trial (start and end): not reported

Follow-up until: 30 days postoperatively

Inclusions:
Neonates (aged less than 1 month) undergoing open heart surgery with CP
Exclusions:
Infusions other than red blood cells or crystalloid in the 2 hours postoperative
FFP or human albumin solution (HAS) been given
Age:
All patients aged less than 1 month but not reported separately for each arm
Ethnicity:
Not reported
Gender:
Not reported
Operations:
10 non-cyanotic heart disease. Not reported separately for each arm of the stuct
Intervention arm:
Transfusion of $20 \mathrm{ml} / \mathrm{kg}$ FFP on admission to ICU postoperatively $(\mathrm{n}=9)$
Comparator arm:

Fresh frozen plasma for cardiovascular surgery (Review)

Copyright @ 2015 The Cochrane Collaboration. Published by John Wiley \& Sons, Ltd. 


\begin{tabular}{ll}
\hline Outcomes & Primary: \\
& Prothrombin fragments $1+2$ post-infusion and 2 hours postoperatively \\
& Other outcomes: \\
& 1. Mortality within 30 days postoperatively \\
& 2. Thromboembolism within 30 days postoperatively \\
& 3. Overt bleeding within 30 days postoperatively \\
& 4. Thrombin-antithrombin complexes post-infusion and 2 hours postoperatively \\
& 5. D-dimers post-infusion and 2 hours postoperatively \\
\hline Notes & - \\
\hline
\end{tabular}

\section{Risk of bias}

\begin{tabular}{|c|c|c|}
\hline Bias & Authors' judgement & Support for judgement \\
\hline $\begin{array}{l}\text { Random sequence generation (selection } \\
\text { bias) }\end{array}$ & Unclear risk & $\begin{array}{l}\text { Insufficient information about the se- } \\
\text { quence generation process to permit judge- } \\
\text { ment }\end{array}$ \\
\hline Allocation concealment (selection bias) & Unclear risk & $\begin{array}{l}\text { Insufficient information about allocation } \\
\text { concealment to permit judgement }\end{array}$ \\
\hline Blinding of participants & Low risk & $\begin{array}{l}\text { Neonates (aged }<1 \text { month) will be unaware } \\
\text { of allocation }\end{array}$ \\
\hline Blinding of personnel & Unclear risk & $\begin{array}{l}\text { Insufficient information about blinding of } \\
\text { personnel to permit judgement }\end{array}$ \\
\hline $\begin{array}{l}\text { Blinding of outcome assessment (detection } \\
\text { bias) } \\
\text { All outcomes }\end{array}$ & Unclear risk & $\begin{array}{l}\text { Insufficient information about blinding of } \\
\text { analysts to permit judgement }\end{array}$ \\
\hline $\begin{array}{l}\text { Incomplete outcome data (attrition bias) } \\
\text { All outcomes }\end{array}$ & Low risk & $\begin{array}{l}2 \text { patients were excluded after randomisa- } \\
\text { tion. This was pre-specified in the protocol }\end{array}$ \\
\hline Selective reporting (reporting bias) & Low risk & All outcomes were reported \\
\hline Equal use of co-interventions in each arm & Low risk & $\begin{array}{l}\text { Quote: "Aprotinin }(30,000 \mathrm{IU} / \mathrm{kg} \text { to the } \\
\text { prime, } 30,000 \mathrm{IU} / \mathrm{kg} \text { as a bolus to the pa- } \\
\text { tient } 1 \mathrm{~h} \text { after the induction of anesthe- } \\
\text { sia, and a steady infusion of } 8,000 \mathrm{IU} / \mathrm{kg} / \\
\mathrm{h} \text { during CPB) was administered to all pa- } \\
\text { tients." "All patients received } 200 \mathrm{IU} \text { pro- } \\
\text { thrombin complex concentrate (PCC, Pro- } \\
\text { thromblex-T TIM 4, Baxter, Vienna, Aus- } \\
\text { tria) after protamine." }\end{array}$ \\
\hline
\end{tabular}


Långström 2008 (Continued)

\begin{tabular}{|c|c|c|}
\hline Balance of baseline factors & Unclear risk & $\begin{array}{l}\text { Insufficient information about baseline fac- } \\
\text { tors to permit judgement }\end{array}$ \\
\hline
\end{tabular}

\section{Martinowitz 1990}

Methods

Type of study: single-centre, randomised, parallel-group, cross-over study. Full-text paper Country: Israel

Dates of trial (start and end): not reported

Follow-up until: not reported

Participants

Inclusions:

1. Adults undergoing open heart surgery with $\mathrm{CPB}$

Exclusions:

1. Aspirin or dipyridamole use in 2 weeks preceding surgery

Age:

Intervention arm: mean 59.4 years (standard deviation 6 years)

Comparator arm: mean 61.8 years (standard deviation 7 years)

Ethnicity:

Not reported

Gender:

Intervention arm: 15 male and 5 female

Comparator arm: 14 male and 6 female

Operations:

Intervention arm: elective surgery only; 12 coronary artery bypass grafts, 6 valve replacements, 1 mitral commissurotomy and 1 atrial septal defect repair

Comparator arm: elective surgery only; 14 coronary bypass grafts, 5 valve replacements and 1 mitral commissurotomy

Interventions

Intervention arm:

Transfusion of FFP (dose not specified) after CPB and heparin neutralisation followed by cross-over at unspecified time to comparator $\operatorname{arm}(n=20)$

Comparator arm:

Transfusion of packed cells (red cells and buffy coat) (dose not specified) after CPB and heparin neutralisation followed by cross-over at unspecified time to intervention arm ( $\mathrm{n}$ $=20)$

Outcomes

Primary:

Platelet function measured by light transmission aggregometry immediately after transfusion

Other outcomes:

1. Blood loss 24 hours postoperatively

2. Blood transfusion requirements 24 hours postoperatively

Notes

Cross-over occurred after platelet function tests were performed but unclear if this occurred before or after 24 hours when transfusion requirements and blood loss were estimated

\section{Risk of bias}

Fresh frozen plasma for cardiovascular surgery (Review) 
Martinowitz 1990 (Continued)

\begin{tabular}{|c|c|c|}
\hline Bias & Authors' judgement & Support for judgement \\
\hline $\begin{array}{l}\text { Random sequence generation (selection } \\
\text { bias) }\end{array}$ & Unclear risk & $\begin{array}{l}\text { Insufficient information about random se- } \\
\text { quence generation to permit judgement }\end{array}$ \\
\hline Allocation concealment (selection bias) & Unclear risk & $\begin{array}{l}\text { Insufficient information about allocation } \\
\text { concealment to permit judgement }\end{array}$ \\
\hline Blinding of participants & Unclear risk & $\begin{array}{l}\text { Insufficient information about blinding of } \\
\text { participants to permit judgement }\end{array}$ \\
\hline Blinding of personnel & Unclear risk & $\begin{array}{l}\text { Insufficient information about blinding of } \\
\text { personnel to permit judgement }\end{array}$ \\
\hline $\begin{array}{l}\text { Blinding of outcome assessment (detection } \\
\text { bias) } \\
\text { All outcomes }\end{array}$ & Unclear risk & $\begin{array}{l}\text { Insufficient information about blinding of } \\
\text { analysts to permit judgement }\end{array}$ \\
\hline $\begin{array}{l}\text { Incomplete outcome data (attrition bias) } \\
\text { All outcomes }\end{array}$ & High risk & $\begin{array}{l}\text { Timing of cross-over unclear. Unclear if pa- } \\
\text { tients were assessed for all outcomes before } \\
\text { cross-over }\end{array}$ \\
\hline Selective reporting (reporting bias) & Low risk & All pre-reported outcomes analysed \\
\hline Equal use of co-interventions in each arm & Low risk & $\begin{array}{l}\text { Operations and techniques similar in both } \\
\text { groups }\end{array}$ \\
\hline Balance of baseline factors & Low risk & $\begin{array}{l}\text { Similar mean age and gender in both } \\
\text { groups. No information on co-morbidities }\end{array}$ \\
\hline
\end{tabular}

McCall 2004

Methods

Type of study: single-centre, parallel-group randomised controlled trial. Full-text paper Country: United States

Dates of trial (start and end): not reported

Follow-up until: 24 hours postoperatively

Participants

Inclusions:

1. Infants undergoing surgery for the first time with $\mathrm{CPB}$

2. Weight less than $8 \mathrm{~kg}$

Exclusions:

1. Pre-existing coagulation disorder

2. Abnormal pre-operative clotting parameters

3. Pre-operative use of anticoagulant or antiplatelet agents

Age:

Intervention arm: mean 4.0 months (standard deviation 3.9 months)

Comparator arm: mean 4.4 months (standard deviation 1.2 months)

Fresh frozen plasma for cardiovascular surgery (Review) 


\begin{tabular}{ll} 
& Ethnicity: \\
& Not reported \\
& Gender: \\
& Not reported \\
& Operations: \\
& Intervention arm: elective surgery only; 7 non-cyanotic heart disease and 3 cyanotic heart \\
disease & Comparator arm: elective surgery only; 8 non-cyanotic heart disease and 2 cyanotic heart \\
disease & Intervention arm: \\
\hline Transfusion with mean $63 \mathrm{ml} / \mathrm{kg}(1 \mathrm{unit}) \mathrm{FFP}$ with CPB priming intra-operatively $(\mathrm{n}=$ \\
\hline Comparator arm: \\
Comentions \\
Standard care (no comparator agent) $(\mathrm{n}=10)$ \\
\hline
\end{tabular}

Outcomes

Primary:

1. Change in fibrinogen concentration at end of $\mathrm{CPB}$

2. Blood transfusion requirements 24 hours postoperatively

Other outcomes:

1. Prothrombin time on admission to ICU postoperatively

2. Activated partial thromboplastin time on admission to ICU postoperatively

3. Haematocrit on admission to ICU postoperatively

4. Blood loss in first 24 hours postoperatively

FFP group had higher fibrinogen levels after bypass and therefore received less cryoprecipitate, which "tended to decrease the overall mean patient exposure to blood products"

\section{Risk of bias}

\begin{tabular}{l|l} 
Bias Authors' judgement $\quad$ Support for judgement
\end{tabular}

Random sequence generation (selection Unclear risk bias)

Allocation concealment (selection bias)
Unclear risk
Insufficient information about random sequence generation to permit judgement

Quote: “on the day before surgery, each patient was randomised, using a series of sealed envelopes, to receive either 1 unit of FFP or no FFP in the CPB pump prime" Comment: does not state whether these were serially numbered, sealed, opaque envelopes

Comment: potential for inadequate concealment during surgery as staff in theatre were required to administer FFP (or not) and make up with albumin, to achieve the desired colloid osmotic pressure, and "due to the colloid osmotic pressure of FFP the patients in the FFP group received less albu- 


\begin{tabular}{|l|l} 
min in the prime than those in the no FFP \\
group." Therefore it was possible that the \\
staff in theatre were aware of which group \\
a patient was in
\end{tabular}

Blinding of participants Low risk

Participants were infants and at this young age are likely to be unaware of their random allocation

Blinding of personnel High risk

Blinding of outcome assessment (detection Unclear risk bias)

All outcomes

Incomplete outcome data (attrition bias) Unclear risk All outcomes
Personnel transfused FFP intra-operatively to those randomised to the FFP group and, consequently, they will not have been blinded to the intervention

Insufficient information about blinding of analysts to permit judgement

Comment: fibrinogen levels were a specified outcome of this study. For low fibrinogen levels after protamine administration, "according to a predetermined protocol" patients would receive "cryoprecipitate $(0.5 \mathrm{U} / \mathrm{kg})$ for a fibrinogen less than $80 \mathrm{mg} /$ $\mathrm{dL}$ ". Note fibrinogen levels much lower in "no FFP" group at end of bypass (58 versus $123 \mathrm{mg} / \mathrm{dL}$ ), so more patients in this group would have received prophylactic cryo at this time - but the number of patients and amount of cryo infused is not stated. However, this would explain why the fibrinogen levels on ICU admission were then the same in both groups. Some data are presented for patients receiving additional blood components "at the discretion of the surgeon and anaesthesiologist" "if bleeding continued" (i.e. to treat bleeding, not for prophylaxis). It is not clear how many patients in total received prophylactic components and of what type intraoperatively Comment: PT and APTT results are presented at baseline but not at end of bypass and differences may have been associated with potential for bleeding. These were not predetermined outcome measures however Comment: haematocrit in the FFP group was slightly but not statistically significantly higher at baseline, which may be the reason they received fewer red cells over- 


\begin{tabular}{|c|c|c|}
\hline & & $\begin{array}{l}\text { all ( } 1.8 \text { versus } 2.1 \text {, but not statistically sig- } \\
\text { nificant). However, there was no differ- } \\
\text { ence in the red cells administered in the } \\
\text { prime. Haematocrit data for end of by- } \\
\text { pass were not presented. Red cells are not } \\
\text { listed among the additional blood compo- } \\
\text { nents transfused prophylactically according } \\
\text { to the post-bypass protocol, or for addi- } \\
\text { tional bleeding prior to admission to ICU }\end{array}$ \\
\hline Selective reporting (reporting bias) & Low risk & All pre-reported outcomes analysed \\
\hline Equal use of co-interventions in each arm & High risk & $\begin{array}{l}\text { FFP group had higher fibrinogen levels af- } \\
\text { ter bypass and therefore received less cryo- } \\
\text { precipitate, which "tended to decrease the } \\
\text { overall mean patient exposure to blood } \\
\text { products" } \\
\text { Comment: treatment with cryoprecipitate } \\
\text { has some similar effects to treatment with } \\
\text { FFP. This may confound the outcomes }\end{array}$ \\
\hline Balance of baseline factors & Low risk & $\begin{array}{l}\text { Similar mean age, weight and co-morbidi- } \\
\text { ties in each group }\end{array}$ \\
\hline
\end{tabular}

Oliver 2003

Methods

Type of study: single-centre, parallel-group randomised controlled trial. Full-text paper Country: United States

Dates of trial (start and end): not reported

Follow-up until: 24 hours postoperatively

Participants

Inclusions:

1. Neonates and infants (age range not defined) undergoing open heart surgery with $\mathrm{CPB}$

2. Weight $10 \mathrm{~kg}$ or less

Exclusions:

1. Pre-existing haematological disease

2. Abnormal pre-operative clotting parameters

3. Severe liver failure

4. Blood transfusion in 24 hours before operation

Age:

Intervention arm: mean 6.9 months (standard deviation 7.4 months)

Comparator arm: mean 6.6 months (standard deviation 5.9 months)

Ethnicity:

Not reported

Gender:

Intervention arm: 17 male and 11 female

Comparator arm: 14 male and 14 female 
Oliver 2003 (Continued)

\begin{tabular}{|c|c|}
\hline & $\begin{array}{l}\text { Operations: } \\
\text { Intervention arm: elective surgery only; } 13 \text { non-cyanotic heart disease and } 15 \text { cyanotic } \\
\text { heart disease } \\
\text { Comparator arm: elective surgery only; } 17 \text { non-cyanotic heart disease and } 11 \text { cyanotic } \\
\text { heart disease }\end{array}$ \\
\hline Interventions & $\begin{array}{l}\text { Intervention arm: } \\
\text { Transfusion with } 1 \text { unit FFP with CPB priming intra-operatively }(\mathrm{n}=28) \\
\text { Comparator arm: } \\
\text { Infusion of } 200 \mathrm{ml} 5 \% \text { HAS with CPB priming intra-operatively }(\mathrm{n}=28)\end{array}$ \\
\hline Outcomes & $\begin{array}{l}\text { Primary: } \\
\text { Blood loss } 24 \text { hours postoperatively } \\
\text { Other outcomes: } \\
\text { 1. Blood transfusion requirements in operating room and } 24 \text { hours postoperatively } \\
\text { 2. Bleeding ('wet surgical field') } 10 \text { minutes after protamine administration } \\
\text { 3. Prothrombin time } 10 \text { minutes after protamine administration and on arrival to ICU } \\
\text { 4. Activated partial thromboplastin time } 10 \text { minutes after protamine administration and } \\
\text { on arrival to ICU } \\
\text { 5. Fibrinogen concentration } 10 \text { minutes after protamine administration } \\
\text { 6. Thromboelastography R time } 10 \text { minutes after protamine administration } \\
\text { 7. Thromboelastography maximum amplitude } 10 \text { minutes after protamine administra- } \\
\text { tion } \\
\text { 8. Return to theatre during study period } \\
\text { 9. Perioperative mortality } \\
\text { 10. ICU admission duration }\end{array}$ \\
\hline Notes & Fibrin glue also used \\
\hline
\end{tabular}

Risk of bias

\begin{tabular}{|c|c|c|}
\hline Bias & Authors' judgement & Support for judgement \\
\hline $\begin{array}{l}\text { Random sequence generation (selection } \\
\text { bias) }\end{array}$ & Unclear risk & $\begin{array}{l}\text { Quote: "Patients were randomised to re- } \\
\text { ceive either } 200 \mathrm{~mL} \text { of albumin } 5 \% \text { or one } \\
\text { unit FP in the prime for CPB" Comment: } \\
\text { how the random sequence was generated is } \\
\text { not described }\end{array}$ \\
\hline Allocation concealment (selection bias) & Unclear risk & $\begin{array}{l}\text { Comment: how allocation was concealed } \\
\text { is not described. Although the patient had } \\
\text { already been recruited to the study at the } \\
\text { time of priming the pump, it remains pos- } \\
\text { sible that the treating clinician may have } \\
\text { been aware of the group to which a patient } \\
\text { had been allocated (e.g. visual cues, as the } \\
\text { products look different) and may have been } \\
\text { able to influence the allocation sequence }\end{array}$ \\
\hline
\end{tabular}


Oliver 2003 (Continued)

\begin{tabular}{|c|c|c|}
\hline Blinding of participants & Unclear risk & $\begin{array}{l}\text { Participants were neonates and infants and } \\
\text { at this young age are likely to be unaware } \\
\text { of their random allocation }\end{array}$ \\
\hline Blinding of personnel & Low risk & $\begin{array}{l}\text { Quote: "All personnel associated with the } \\
\text { perioperative care of these infants and chil- } \\
\text { dren except the perfusionists were blinded } \\
\text { to the constitution of the prime" }\end{array}$ \\
\hline $\begin{array}{l}\text { Blinding of outcome assessment (detection } \\
\text { bias) } \\
\text { All outcomes }\end{array}$ & Unclear risk & $\begin{array}{l}\text { Insufficient information about blinding of } \\
\text { analysts to permit judgement }\end{array}$ \\
\hline $\begin{array}{l}\text { Incomplete outcome data (attrition bias) } \\
\text { All outcomes }\end{array}$ & Low risk & All patients analysed \\
\hline Selective reporting (reporting bias) & Low risk & All pre-reported outcomes analysed \\
\hline Equal use of co-interventions in each arm & High risk & $\begin{array}{l}\text { Similar numbers of patients undergoing } \\
\text { each type of surgery. In addition to the } \\
\text { study intervention, patients in the con- } \\
\text { trol group were given } 0.6 \pm 0.7 \text { units FFP } \\
\text { whereas those in the FFP group received } \\
\text { an additional } 0.3 \pm 0.5 \text { units FFP. This } \\
\text { may confound the outcomes. Cryoprecipi- } \\
\text { tate transfusions were equal in both groups }\end{array}$ \\
\hline Balance of baseline factors & Low risk & Similar age, weight and co-morbidities \\
\hline
\end{tabular}

Snow 1982

Methods

Type of study: single-centre, parallel-group randomised controlled trial. Full-text paper Country: United States

Dates of trial (start and end): not reported

Follow-up until: 48 hours postoperatively

Participants

Inclusions:

1. Adults undergoing cardiac surgery with $\mathrm{CPB}$

Exclusions:

Not reported

Age:

Not reported

Ethnicity:

Not reported

Gender:

Intervention arm: 19 male and 7 female

Comparator arm: 24 male and 3 female

Operations: 
Intervention arm: elective surgery only; 20 coronary artery bypass grafts, 1 combined coronary artery bypass graft and mitral valve replacement, 1 aortic valve replacement, 1 mitral valve replacement, 1 atrial septal defect repair and 1 coronary artery bypass graft and septal myomectomy

Comparator arm: elective surgery only; 23 coronary artery bypass grafts, 1 combined coronary artery bypass graft and aortic valve replacement and 1 mitral valve replacement

\begin{tabular}{ll} 
Interventions & $\begin{array}{l}\text { Intervention arm: } \\
\text { Transfusion of mean of } 3.5 \text { units FFP at time of heparin neutralisation }(\mathrm{n}=26) \\
\text { Comparator arm: } \\
\text { Standard care (no comparator agent) }(\mathrm{n}=27)\end{array}$ \\
\hline Outcomes & $\begin{array}{l}\text { Primary: } \\
\text { Not reported } \\
\text { Other outcomes: } \\
\text { 1. Blood transfusion requirements (time scale not reported) postoperatively } \\
\text { 2. Prothrombin time immediately postoperatively and at } 24 \text { and } 48 \text { hours postoperatively } \\
\text { 3. Fibrinogen concentration immediately postoperatively and at } 24 \text { and } 48 \text { hours post- } \\
\text { operatively } \\
\text { 4. Haematocrit immediately postoperatively and at } 24 \text { and } 48 \text { hours postoperatively } \\
\text { 5. Return to theatre during admission } \\
\text { 6. Postoperative blood loss (time scale not reported) }\end{array}$ \\
\hline \multirow{2}{*}{ Notes } & - \\
\hline
\end{tabular}

Risk of bias

\begin{tabular}{|c|c|c|}
\hline Bias & Authors' judgement & Support for judgement \\
\hline $\begin{array}{l}\text { Random sequence generation (selection } \\
\text { bias) }\end{array}$ & High risk & $\begin{array}{l}\text { Quote: "Fifty-three consecutive patients } \\
\text { were studied in a randomised prospective } \\
\text { manner, using hospital numbers" }\end{array}$ \\
\hline Allocation concealment (selection bias) & Unclear risk & $\begin{array}{l}\text { Insufficient information about allocation } \\
\text { concealment to permit judgement }\end{array}$ \\
\hline Blinding of participants & Unclear risk & $\begin{array}{l}\text { Insufficient information about blinding of } \\
\text { participants to permit judgement }\end{array}$ \\
\hline Blinding of personnel & High risk & $\begin{array}{l}\text { Personnel transfused FFP postoperatively } \\
\text { to those randomised to the FFP group } \\
\text { and, consequently, they will not have been } \\
\text { blinded to the intervention }\end{array}$ \\
\hline $\begin{array}{l}\text { Blinding of outcome assessment (detection } \\
\text { bias) } \\
\text { All outcomes }\end{array}$ & Unclear risk & $\begin{array}{l}\text { Insufficient information about blinding of } \\
\text { analysts to permit judgement }\end{array}$ \\
\hline
\end{tabular}

All outcomes 
Snow 1982 (Continued)

\begin{tabular}{l|l|l}
$\begin{array}{l}\text { Incomplete outcome data (attrition bias) } \\
\text { All outcomes }\end{array}$ & Low risk & $\begin{array}{l}\text { Results as presented do not state how many } \\
\text { patients completed study but no patients } \\
\text { are described as not completing the study }\end{array}$ \\
\hline Selective reporting (reporting bias) & Low risk & All pre-reported outcomes analysed \\
\hline Equal use of co-interventions in each arm & Low risk & Operations and techniques similar in both \\
\hline Balance of baseline factors & Unclear risk & groups \\
\hline
\end{tabular}

\section{Trimble 1964}

\begin{tabular}{|c|c|}
\hline Methods & $\begin{array}{l}\text { Type of study: single-centre, parallel-group randomised controlled trial. Full-text paper } \\
\text { Country: United Kingdom } \\
\text { Dates of trial (start and end): not reported } \\
\text { Follow-up until: } 24 \text { hours postoperatively }\end{array}$ \\
\hline Participants & $\begin{array}{l}\text { Inclusions: } \\
\text { 1. Adults (15 years or more) and children (under } 15 \text { years of age) undergoing cardiac } \\
\text { surgery with CPB (analysed as separate groups) } \\
\text { Exclusions: } \\
\text { Not reported } \\
\text { Age: } \\
\text { Not reported } \\
\text { Ethnicity: } \\
\text { Not reported } \\
\text { Gender: } \\
\text { Not reported } \\
\text { Operations: } \\
\text { Not reported. Mix of elective and emergency patients not reported }\end{array}$ \\
\hline Interventions & $\begin{array}{l}\text { Adults } \\
\text { Intervention arm: } \\
\text { Postoperative transfusion of } 2 \text { units }(500 \mathrm{ml}) \mathrm{FFP} \text { after } \mathrm{CPB} \text { and heparin neutralisation } \\
(\mathrm{n}=15) \\
\text { Comparator arm: } \\
\text { Standard care (no comparator agent) }(\mathrm{n}=25) \\
\text { Children } \\
\text { Intervention arm: } \\
\text { Postoperative transfusion of } 1 \text { unit }(250 \mathrm{ml}) \mathrm{FFP} \text { after CPB and heparin neutralisation } \\
(\mathrm{n}=6) \\
\text { Comparator arm: } \\
\text { Standard care (no comparator agent) }(\mathrm{n}=7)\end{array}$ \\
\hline
\end{tabular}


Trimble 1964 (Continued)

\begin{tabular}{ll}
\hline Outcomes & Adults \\
& Primary: \\
& Postoperative blood loss 24 and 48 hours postoperatively \\
& Other outcomes: \\
& Not reported \\
& Children \\
& Primary: \\
& Postoperative blood loss 24 hours postoperatively \\
& Other outcomes: \\
& Return to theatre in study period \\
\hline Notes & Adults and children were analysed separately \\
\hline
\end{tabular}

\section{Risk of bias}

\begin{tabular}{|c|c|c|}
\hline Bias & Authors' judgement & Support for judgement \\
\hline $\begin{array}{l}\text { Random sequence generation (selection } \\
\text { bias) }\end{array}$ & Low risk & $\begin{array}{l}\text { Quote: "The patients were divided into two } \\
\text { groups by reference to a series of random } \\
\text { numbers" }\end{array}$ \\
\hline Allocation concealment (selection bias) & Unclear risk & $\begin{array}{l}\text { Insufficient information about allocation } \\
\text { concealment to permit judgement }\end{array}$ \\
\hline Blinding of participants & Unclear risk & $\begin{array}{l}\text { Insufficient information about blinding of } \\
\text { participants to permit judgement }\end{array}$ \\
\hline Blinding of personnel & Unclear risk & $\begin{array}{l}\text { Personnel transfused FFP postoperatively } \\
\text { to those randomised to the FFP group } \\
\text { and, consequently, they will not have been } \\
\text { blinded to the intervention }\end{array}$ \\
\hline $\begin{array}{l}\text { Blinding of outcome assessment (detection } \\
\text { bias) } \\
\text { All outcomes }\end{array}$ & Unclear risk & $\begin{array}{l}\text { Insufficient information about blinding of } \\
\text { analysts to permit judgement }\end{array}$ \\
\hline $\begin{array}{l}\text { Incomplete outcome data (attrition bias) } \\
\text { All outcomes }\end{array}$ & Low risk & $\begin{array}{l}\text { Results as presented do not state how many } \\
\text { patients completed study but no patients } \\
\text { are described as not completing the study }\end{array}$ \\
\hline Selective reporting (reporting bias) & Low risk & All pre-reported outcomes analysed \\
\hline Equal use of co-interventions in each arm & Unclear risk & $\begin{array}{l}\text { Insufficient information about co-inter- } \\
\text { ventions to permit judgement. In adults the } \\
\text { mean perfusion time was lower in the group } \\
\text { receiving FFP ( } 87 \text { minutes) than controls } \\
\text { (131 minutes) }\end{array}$ \\
\hline
\end{tabular}


Trimble 1964 (Continued)

Balance of baseline factors

Unclear risk
Insufficient information about balance of baseline factors to permit judgement. In children the mean age was lower in the group receiving FFP (5.5 years) than controls ( 8.5 years)

Tølløfsrud 2003

Methods

Type of study: single-centre, parallel-group randomised controlled trial. Full-text paper Country: Norway

Dates of trial (start and end): not reported

Follow-up until: 6 months postoperatively

Participants

Inclusions:

Adults (over age of 18 years) undergoing cardiac surgery with $\mathrm{CPB}$

Exclusions:

1. Emergency coronary surgery

2. Unstable angina pectoris

3. History of exposure to viral hepatitis during the last 6 months

4. History of hypersensitivity to blood products

5. IgA deficiency with documented antibodies against IgA

6 . History of drug abuse or suspected drug abuse

7. Pregnancy

8. Current participation in another clinical study or during the past 3 months Age:

Arm 1: mean 71 years (standard deviation 10.1 years)

Arm 2: mean 69.9 years (standard deviation 10.1 years)

Arm 3: mean 67.6 years (standard deviation 12.5 years)

Ethnicity:

Not reported

Gender:

Arm 1: 13 male and 12 female

Arm 2: 5 male and 6 female

Arm 3: 11 male and 8 female

Operations:

Elective surgery only. Individual operation types not reported

Interventions

FFP given therapeutically for the following indications:

1. Reversal of warfarin

2. Increase heparin effect in case of low antithrombin III

3. Non-surgical bleeding after optimising coagulation status with protamine sulphate, desmopressin acetate, tranexamic acid and normothermia

4. Massive surgical bleeding to supply coagulation factors

Arm 1:

10 to $20 \mathrm{ml} / \mathrm{kg}$ Uniplas (FFP) for patients with blood group A, B or AB ( $\mathrm{n}=25)$

Arm 2:

10 to $20 \mathrm{ml} / \mathrm{kg}$ Uniplas (FFP) for patients with blood group $\mathrm{O}(\mathrm{n}=11)$

Arm 3: 
Tølløfsrud 2003

\begin{tabular}{|c|c|}
\hline & $\begin{array}{l}10 \text { to } 20 \mathrm{ml} / \mathrm{kg} \text { Octaplas (FFP) ABO unselected }(\mathrm{n}=19) \\
\text { Controls } \\
\text { Patients undergoing cardiac surgery who were not randomised }(\mathrm{n}=29) \text { (not included in } \\
\text { systematic review) }\end{array}$ \\
\hline Outcomes & $\begin{array}{l}\text { Primary: } \\
\text { 1. Maximum increase in complement factor } 3 \mathrm{bc}(\mathrm{C} 3 \mathrm{bc}) \\
\text { 2. Incidence of anti-A or anti-B mediated transfusion reactions in } 48 \text { hours postopera- } \\
\text { tively } \\
\text { Other outcomes: } \\
\text { 1. Adverse events in } 48 \text { hours postoperatively } \\
\text { 2. Incidence of positive viral tests in } 6 \text { months postoperatively (hepatitis B virus surface } \\
\text { antigen and IgG antibodies against HBV core antigen; hepatitis C virus, human immun- } \\
\text { odeficiency virus } 1+2 \text {; human T-lymphotrophic virus } 1+2 \text {; cytomegalovirus; hepatitis } \\
\text { A virus; and parvovirus B19) } \\
\text { 3. Changes in vital signs in } 48 \text { hours postoperatively } \\
\text { 4. APTT after surgery, } 24 \text { hours and } 48 \text { hours } \\
\text { 5. Activated clotting time after surgery, } 24 \text { hours and } 48 \text { hours } \\
\text { 5. Mortality (perioperative and up to } 7 \text { months postoperatively) } \\
\text { 7. Return to theatre during the study period }\end{array}$ \\
\hline
\end{tabular}

Notes

Used for treatment of bleeding rather than prophylaxis. In some cases, used for warfarin reversal at a dose of 5 to $8 \mathrm{ml} / \mathrm{kg}$. 'Control group' were patients that were not randomised, so have not been included in the analysis. One patient in the Octaplas group, received 2 units of Uniplas (out of a total of 6 units) due to a protocol violation

Risk of bias

\begin{tabular}{|c|c|c|}
\hline Bias & Authors' judgement & Support for judgement \\
\hline $\begin{array}{l}\text { Random sequence generation (selection } \\
\text { bias) }\end{array}$ & Unclear risk & $\begin{array}{l}\text { How the random sequence was generated } \\
\text { was not described }\end{array}$ \\
\hline Allocation concealment (selection bias) & Unclear risk & $\begin{array}{l}\text { Quote: "The patients were randomised 2:1 } \\
\text { to receive Uniplas or Octaplas AB, respec- } \\
\text { tively, by drawing sealed envelopes" }\end{array}$ \\
\hline Blinding of participants & Unclear risk & $\begin{array}{l}\text { Insufficient information about blinding of } \\
\text { participants to permit judgement }\end{array}$ \\
\hline Blinding of personnel & High risk & $\begin{array}{l}\text { Quote: "The study was observer-blinded } \\
\text { with respect to all laboratories, but not to } \\
\text { the administrator of the study drug" }\end{array}$ \\
\hline $\begin{array}{l}\text { Blinding of outcome assessment (detection } \\
\text { bias) }\end{array}$ & Unclear risk & $\begin{array}{l}\text { Insufficient information about blinding of } \\
\text { analysts to permit judgement }\end{array}$ \\
\hline
\end{tabular}

All outcomes 
Tølløfsrud 2003

\begin{tabular}{lll}
\hline $\begin{array}{l}\text { Incomplete outcome data (attrition bias) } \\
\text { All outcomes }\end{array}$ & Low risk & All patients analysed \\
\hline Selective reporting (reporting bias) & Unclear risk & No outcomes stated in methods \\
\hline Equal use of co-interventions in each arm & Low risk & Equal use of interventions in both arms \\
\hline Balance of baseline factors & Low risk & Similar gender ratio and comorbidities \\
\hline
\end{tabular}

\section{Wilhelmi 2001}

Methods

Type of study: single-centre randomised controlled trial. Full-text paper

Country: Germany

Dates of trial (start and end): September 2007 to April 2008

Follow-up until: 24 hours postoperatively

\begin{tabular}{|c|c|}
\hline Participants & $\begin{array}{l}\text { Inclusions: } \\
\text { 1. Adults undergoing cardiac surgery with coronary artery bypass surgery (with or without } \\
\text { CPB) } \\
\text { Exclusions: } \\
\text { 1. Previous cardiac surgery procedures } \\
\text { 2. Antiplatelet agents in } 72 \text { hours prior to surgery } \\
\text { 3. Known coagulation disorders } \\
\text { 4. Left ventricular ejection fraction }<40 \% \\
\text { Age: } \\
\text { Intervention arm: mean } 63 \text { years (standard deviation } 8 \text { years) } \\
\text { Comparator arm: mean } 65 \text { years (standard deviation } 7 \text { years) } \\
\text { Ethnicity: } \\
\text { Not reported } \\
\text { Gender: } \\
\text { Intervention arm: } 43 \text { male and } 17 \text { female } \\
\text { Comparator arm: } 44 \text { male and } 16 \text { female } \\
\text { Operations: } \\
\text { Intervention arm: } 60 \text { elective coronary artery bypass grafts with CPB } \\
\text { Comparator arm: } 58 \text { elective coronary artery bypass grafts with CPB and } 2 \text { emergency } \\
\text { coronary artery bypass grafts with CPB }\end{array}$ \\
\hline Interventions & $\begin{array}{l}\text { Intervention arm: } \\
\text { Transfusion of } 4 \text { units }(1000 \mathrm{ml}) \text { FFP after CPB and heparin neutralisation }(\mathrm{n}=60) \\
\text { Comparator arm: } \\
\text { Transfusion of } 1000 \mathrm{ml} \text { hydroxyethyl starch (HES) after CPB and heparin neutralisation } \\
(\mathrm{n}=60)\end{array}$ \\
\hline Outcomes & $\begin{array}{l}\text { Primary: } \\
\text { Not stated } \\
\text { Other outcomes: } \\
\text { 1. Postoperative blood loss after } 6 \text { and } 24 \text { hours } \\
\text { 2. Haematocrit on admission to ICU and } 24 \text { hours postoperatively }\end{array}$ \\
\hline
\end{tabular}


3. Prothrombin time on admission to ICU; 3,6 and 24 hours after transfusion of FFP or HES; and on discharge from hospital

4. Activated partial thromboplastin time on admission to ICU; 3, 6 and 24 hours after transfusion of FFP or HES; and on discharge from hospital

5. Mortality up to day 9

6. Return to theatre during admission

7. ICU admission duration

8. Red cell transfusions during hospital admission

Notes

Block randomisation. All patients treated with FFP operated on first, followed by control group. 4 units $(1000 \mathrm{ml}) \mathrm{FFP}$ given in either arm if excessive bleeding postoperatively

\section{Risk of bias}

\begin{tabular}{|c|c|c|}
\hline Bias & Authors' judgement & Support for judgement \\
\hline $\begin{array}{l}\text { Random sequence generation (selection } \\
\text { bias) }\end{array}$ & High risk & $\begin{array}{l}\text { Quote: "Patients were block-randomised } \\
\text { into groups of } n=60 \text { patients. All patients } \\
\text { in the FFP group were operated on first, } \\
\text { followed by the } 60 \text { control patients." }\end{array}$ \\
\hline
\end{tabular}

Allocation concealment (selection bias) High risk

Not concealed, as FFP group were all operated on first

\begin{tabular}{l|l|l} 
Blinding of participants & High risk & $\begin{array}{l}\text { Not blinded, as FFP group were all oper- } \\
\text { ated on first }\end{array}$ \\
\hline Blinding of personnel & High risk & $\begin{array}{l}\text { Not blinded, as FFP group were all oper- } \\
\text { ated on first }\end{array}$
\end{tabular}
ated on first

Blinding of outcome assessment (detection High risk bias)

Not blinded, as FFP group were all operated on first

All outcomes

Incomplete outcome data (attrition bias) Low risk All patients analysed

All outcomes

Selective reporting (reporting bias) Low risk

All pre-reported outcomes analysed

Equal use of co-interventions in each arm Low risk

Operations and techniques similar in both groups with the same 2 surgeons performing all the operations. Additional FFP could be given to both groups but the mean volumes given to both groups were substantially different ( 4 units in FFP group and 0.2 units in control group) 
Wilhelmi 2001 (Continued)

Balance of baseline factors Low risk
Similar age, gender, rates of pre-operative infarction and pulmonary function tests in both groups

APTT: activated partial thromboplastin time

CPB: cardiopulmonary bypass

FFP: fresh frozen plasma

HAS: human albumin solution

HBV: hepatitis B

HES: hydroxyethyl starch

ICU: intensive care unit

INR: international normalised ratio

PT: prothrombin time

Characteristics of excluded studies [ordered by study ID]

\begin{tabular}{|c|c|}
\hline Study & Reason for exclusion \\
\hline Armellin 2001 & Ineligible intervention: trial of plasmapheresis \\
\hline Bilgin 2011 & $\begin{array}{l}\text { Ineligible intervention: this paper is a post hoc analysis of a randomised controlled trial of } 2 \text { types of red } \\
\text { blood cells }\end{array}$ \\
\hline Boldt 1989 & $\begin{array}{l}\text { Ineligible intervention: trial of plasmapheresis } \\
\text { Potentially associated with fabrication of results }\end{array}$ \\
\hline Boldt 1990 & $\begin{array}{l}\text { Ineligible intervention: trial of plasmapheresis } \\
\text { Potentially associated with fabrication of results }\end{array}$ \\
\hline Boldt 1993 & $\begin{array}{l}\text { Ineligible intervention: trial of plasmapheresis } \\
\text { Potentially associated with fabrication of results }\end{array}$ \\
\hline Chapanduka 2002 & Ineligible study type: consecutive series; not a randomised controlled trial \\
\hline Demeyere 2010 & Ineligible intervention: trial of FFP versus prothrombin complex concentrate for warfarin reversal \\
\hline Frenzel 2008 & Ineligible intervention: this is a study of anticoagulants and not of interventions to prevent or stop bleeding \\
\hline Haubelt 2002 & Ineligible study type: consecutive series, not a randomised controlled trial \\
\hline Hertfelder 1992 & Ineligible intervention: comparison of platelet-rich plasma with fresh whole blood \\
\hline
\end{tabular}


(Continued)

Lancé 2012

Ineligible intervention: the study compared 2 units of FFP transfused alongside $2 \mathrm{~g}$ of fibrinogen concentrate with 4 units of FFP. We did not include a category for 2 comparisons of the same product within a study in this review

Menges $2006 \quad$ Ineligible intervention: trial of plasmapheresis

Potentially associated with fabrication of results

Safwat 2002

Ineligible intervention: trial of platelet plasmapheresis

von Sommoggy 1990 Ineligible intervention: combination of FFP and human albumin compared with hydroxyethyl starch

Yiu 2006

Ineligible intervention: study of reversal of warfarin

FFP: fresh frozen plasma

Characteristics of studies awaiting assessment [ordered by study ID]

Miao 2014

Methods Type of study: single-centre, parallel-group randomised controlled trial. Full-text paper

Country: China

Dates of trial (start and end): February 2013 to October 2013

Follow-up until: until hospital discharge

Participants

Inclusions:

1. Children aged 6 months to 3 years undergoing cardiac surgery with CPB for congenital cyanotic heart disease

Exclusions:

1. Haemoglobin less than $150 \mathrm{~g} / \mathrm{l}$

2. Known coagulation disorders

3. Renal insufficiency

4. Hepatic insufficiency

5. Anticoagulant medications

6. Previous cardiac surgery procedures

7. Emergency surgery

8. Critically ill patient

Age:

Intervention arm: mean 15.6 months (standard deviation 7.7 months)

Comparator arm: mean 14.7 months (standard deviation 8.1 months)

Ethnicity:

Not reported

Gender:

Intervention arm: 24 male and 22 female

Comparator arm: 27 male and 18 female

Operations:

Intervention arm: elective surgery only; all patients had cyanotic heart disease 
Miao 2014 (Continued)

Comparator arm: elective surgery only; all patients had cyanotic heart disease

$\begin{array}{ll}\text { Interventions } & \text { Intervention arm: } \\ & \text { Transfusion of } 10 \text { to } 20 \mathrm{ml} / \mathrm{kg} \text { FFP with CPB priming }(\mathrm{n}=46) \\ & \text { Comparator arm: } \\ & \text { Transfusion of } 10 \text { to } 20 \mathrm{ml} / \mathrm{kg} \text { gelofusine with CPB priming }(\mathrm{n}=45)\end{array}$

Outcomes

Primary:

Change in haemostatic parameters measured by thromboelastography postoperatively

Other outcomes:

1. Postoperative blood loss 6 hours and 24 hours postoperatively and total blood loss before discharge

2. Red cell transfusions postoperatively

3. Platelet transfusions postoperatively

4. Need for pharmacological agents (prothrombin complex concentrate and fibrinogen concentrate) to control bleeding postoperatively

5. ICU admission duration

6. Total length of hospital admission

7. Return to theatre during admission

8. Renal function postoperatively

Notes

Miao 2015

Methods Type of study: single-centre, parallel-group randomised controlled trial. Full-text paper Country: China

Dates of trial (start and end): December 2012 to March 2013

Follow-up until: until hospital discharge

Participants

Inclusions:

1. Children aged 6 months to 3 years undergoing cardiac surgery with $\mathrm{CPB}$

2. Weight 5 to $15 \mathrm{~kg}$

Exclusions:

1. Previous cardiac surgery procedures

2. Known coagulation disorders

3. Renal insufficiency

4. Hepatic insufficiency

5. Anticoagulant medications

6. Emergency surgery

7. Critically ill patients

Age:

Intervention arm: mean 11.8 months (standard deviation 8.2 months)

Comparator arm: mean 12.7 months (standard deviation 9.5 months)

Ethnicity:

Not reported

Gender:

Intervention arm: 20 male and 17 female

Comparator arm: 18 male and 20 female

Fresh frozen plasma for cardiovascular surgery (Review) 
Miao 2015 (Continued)

Operations:

Intervention arm: elective surgery only; 13 non-cyanotic heart disease and 15 cyanotic heart disease

Comparator arm: elective surgery only; 22 non-cyanotic heart disease and 15 cyanotic heart disease

$\begin{array}{ll}\text { Interventions } & \text { Intervention arm: } \\ & \text { Transfusion of } 1 \text { to } 2 \text { units FFP with CPB priming }(\mathrm{n}=37) \\ & \text { Comparator arm: } \\ & \text { Transfusion of } 10 \text { to } 20 \mathrm{ml} / \mathrm{kg} \text { gelofusine with CPB priming }(\mathrm{n}=38)\end{array}$

Outcomes Primary:

Change in haemostatic parameters measured by thromboelastography postoperatively

Other outcomes:

1. Postoperative blood loss after 24 hours postoperatively and blood loss until discharge

2. Red cell transfusions during ICU admission

3. Platelet transfusions during ICU admission

4. Need for pharmacological agents (prothrombin complex concentrate and fibrinogen concentrate) to control bleeding during ICU admission

5. ICU admission duration

6. Total length of hospital admission

7. Return to theatre during admission

8. Postoperative haematocrit

Notes

CPB: cardiopulmonary bypass

FFP: fresh frozen plasma

ICU: intensive care unit

Characteristics of ongoing studies [ordered by study ID]

\section{ACTRN12613001279718}

\begin{tabular}{|c|c|}
\hline Trial name or title & 'Prothrombinex-VF vs fresh frozen plasma for the treatment of bleeding post-cardiopulmonary bypass' \\
\hline Methods & $\begin{array}{l}\text { Type of study: multi-centre, parallel-group randomised controlled trial } \\
\text { Follow-up until: } 30 \text { days postoperatively }\end{array}$ \\
\hline Participants & $\begin{array}{l}\text { Inclusion: } \\
\text { 1. Patients undergoing cardiac surgery requiring cardiopulmonary bypass and determined to have non-surgical } \\
\text { bleeding post heparin reversal } \\
\text { 2. Age } 18 \text { to } 100 \text { years } \\
\text { Exclusion: } \\
\text { 1. Patients with pre-existing bleeding diatheses } \\
\text { 2. Patients receiving Prothrombinex VF or FFP less than } 5 \text { days before CPB } \\
\text { 3. Patients receiving a heart or lung transplant } \\
\text { 4. Patients undergoing implant of ventricular assist devices }\end{array}$ \\
\hline
\end{tabular}

Fresh frozen plasma for cardiovascular surgery (Review)

Copyright @ 2015 The Cochrane Collaboration. Published by John Wiley \& Sons, Ltd. 


\section{ACTRN12613001279718 (Continued)}

\begin{tabular}{ll}
\hline Interventions & $\begin{array}{l}\text { Intervention arm: } \\
\text { Human } 3 \text { factor prothrombin complex concentrate (Prothrombinex-VF) 25 IU/kg for first-line treatment of } \\
\text { non-surgical bleeding post-cardiopulmonary bypass } \\
\text { Comparator arm: } \\
\text { FFP } 15 \mathrm{ml} / \mathrm{kg} \text { for first-line treatment of non-surgical bleeding post-cardiopulmonary bypass }\end{array}$ \\
\hline Outcomes & $\begin{array}{l}\text { Primary outcome: } \\
\text { Composite outcomes of requirements for red cell or platelet transfusion up to } 24 \text { hours postoperatively } \\
\text { Other outcomes: } \\
\text { 1. Chest drain output at } 6 \text { and } 24 \text { hours postoperatively } \\
\text { 2. ICU arrival haemoglobin } \\
\text { 3. Incidence of thrombotic complications (during hospital admission) } \\
\text { 4. Length of stay on ICU } \\
\text { 5. Length of stay in hospital } \\
\text { 6. Overall mortality at } 30 \text { days } \\
\text { 7. Respiratory indices (P:F ratios) at } 6 \text { and } 12 \text { hours postoperatively } \\
\text { 8. Total surgical red cell loss at postoperative day } 5\end{array}$ \\
\hline Starting date & 13 January 2014 \\
\hline Contact information & Principal investigator: Warren Pavey (warren.pavey@health.wa.gov.au) \\
\hline Notes & -
\end{tabular}

EudraCT: 2009-016709-41

Trial name or title 'Coagulopathy during surgery for the repair of extent 4 thoraco-abdominal aortic aneurysms - feasibility study of the use of fibrinogen concentrate infusion in place of fresh frozen plasma'

Methods Type of study: single-centre randomised controlled trial

Follow-up until: 24 hours postoperatively

Participants Inclusion:

1. Undergoing elective extent 4 thoracoabdominal aneurysm repair

2. Over 18 years of age

3. Able to give written informed consent

Exclusion:

1. Re-do surgery

2. Surgery for ruptured aneurysm

3. Pregnancy

4. Females of child bearing age (age $<45$ years) not using medically approved method of contraception

5. Congenital coagulopathy

6. Known allergy to study drug

Interventions

Intervention arm:

Intra-operative infusion of fibrinogen concentrate $2 \mathrm{~g} /$ hour

Comparator arm:

Intra-operative transfusion of FFP 
EudraCT: 2009-016709-41 (Continued)

\begin{tabular}{|c|c|}
\hline Outcomes & $\begin{array}{l}\text { Primary outcome: } \\
\text { Pattern of coagulation disturbance (individual coagulation factor levels; von Willebrand factor; and thrombin } \\
\text { generation) intraoperatively and up to } 24 \text { hours postoperatively } \\
\text { Other outcomes: } \\
\text { 1. Blood loss } \\
\text { 2. Red cell, FFP and platelet transfusions intraoperatively } \\
\text { 3. Morbidity } \\
\text { 4. Length of stay } \\
\text { 5. Mortality }\end{array}$ \\
\hline Starting date & 26 January 2010 \\
\hline Contact information & $\begin{array}{l}\text { Principal investigators: Alastair Nimmo (a.nimmo@ed.ac.uk) and Gary Morrison (gary.morrison@luht.scot. } \\
\text { nhs.uk) }\end{array}$ \\
\hline Notes & - \\
\hline
\end{tabular}

EudraCT: 2014-000452-28

Trial name or title 'Vasculopathic Injury and Plasma as Endothelial Rescue - OCTAplas Trial (VIPER-OCTA)'

\begin{tabular}{ll}
\hline Methods & $\begin{array}{l}\text { Type of study: single-centre randomised controlled trial } \\
\text { Follow-up until: } 90 \text { days postoperatively }\end{array}$ \\
\hline Participants & $\begin{array}{l}\text { Inclusion: } \\
\text { 1. Patient undergoing emergency surgery with cardiopulmonary bypass pump for a thoracic aortic dissection } \\
\text { 2. Over } 18 \text { years age } \\
\text { 3. Consent obtainable from patient or by proxy (independent physician and/or next of kin) } \\
\text { Exclusion: } \\
\text { 1. Documented refusal of blood transfusion } \\
\text { 2. FFP transfusion before randomisation } \\
\text { 3. Aortic dissection due to trauma } \\
\text { 4. Treatment with GPIIb/IIIa inhibitors less than } 24 \text { hours from screening } \\
\text { 5. Withdrawal from active therapy } \\
\text { 6. Expected to die less than } 24 \text { hours from screening } \\
\text { 7. Previously within } 30 \text { days included in a randomised trial, if known at the time of enrolment } \\
\text { 8. Known IgA deficiency with documented antibodies against IgA } \\
\text { 9. Known hypersensitivity to OctaplasLG®: the active substance, any of the excipients (sodium citrate } \\
\text { dihydrate, sodium dihydrogen phosphate dihydrate or glycine) or residues from the manufacturing process } \\
\text { (Tri (N-Butyl) Phosphate (TNBP) and Octoxynol (Triton X-100)) } \\
\text { 10. Known severe deficiencies of protein S } \\
\text { 11. Pregnancy (non-pregnancy confirmed by patient being postmenopausal or having a negative serum-hCG) }\end{array}$ \\
\hline
\end{tabular}

Interventions Intervention arm:

OctaplasLG

Comparator arm:

Fresh frozen plasma 
EudraCT: 2014-000452-28 (Continued)

\begin{tabular}{|c|c|}
\hline Outcomes & $\begin{array}{l}\text { Primary outcome: } \\
\text { Plasma levels of endothelial markers (Syndecan-1, soluble thrombomodulin, sE-selectin, sVE-cadherin) at } 24 \\
\text { hours postoperatively } \\
\text { Other outcomes: } \\
\text { 1. Plasma levels of endothelial markers (Syndecan-1, soluble thrombomodulin, sE-selectin, sVE-cadherin) at } \\
48 \text { hours postoperatively } \\
\text { 2. Acute kidney injury according to RIFLE criteria in the first } 7 \text { postoperative days } \\
\text { 3. Renal replacement therapy in the first } 7 \text { postoperative days } \\
\text { 4. Sepsis-related organ failure assessment: worst score in the first } 7 \text { postoperative days } \\
\text { 5. Mortality at } 30 \text { days and } 90 \text { days postoperatively } \\
\text { 6. C-reactive protein, interleukin-6, catecholamines at } 24 \text { hours and } 48 \text { hours postoperatively } \\
\text { 7. Length of stay in ICU and hospital assessed at } 30 \text { days and } 90 \text { days } \\
\text { 8. Severe adverse reactions in the first } 30 \text { postoperative days } \\
\text { 9. Transfusion-associated acute lung injury in the first } 30 \text { postoperative days } \\
\text { 10. Transfusion-associated circulatory overload in the first } 30 \text { postoperative days }\end{array}$ \\
\hline Starting date & November 2014 \\
\hline Contact information & Principal investigators: Jakob Stensballe (stensballe@rh.dk) and Pär I Johansson (per.johansson@regionh.dk) \\
\hline Notes & - \\
\hline
\end{tabular}

CPB: cardiopulmonary bypass

FFP: fresh frozen plasma

ICU: intensive care unit 
DATA AND ANALYSES

Comparison 1. Fresh frozen plasma versus no plasma

\begin{tabular}{|c|c|c|c|c|}
\hline Outcome or subgroup title & $\begin{array}{l}\text { No. of } \\
\text { studies }\end{array}$ & $\begin{array}{c}\text { No. of } \\
\text { participants }\end{array}$ & Statistical method & Effect size \\
\hline $\begin{array}{l}1 \text { Short-term mortality (up to } 30 \\
\text { days) }\end{array}$ & 6 & & Peto Odds Ratio (Peto, Fixed, 95\% CI) & Totals not selected \\
\hline $\begin{array}{l}2 \text { Serious organ damage - } \\
\text { myocardial infarction }\end{array}$ & 1 & 120 & Risk Ratio (M-H, Random, 95\% CI) & $0.0[0.0,0.0]$ \\
\hline $\begin{array}{l}3 \text { Serious organ damage - renal } \\
\text { failure }\end{array}$ & 1 & & Mean Difference (IV, Random, 95\% CI) & Totals not selected \\
\hline $\begin{array}{l}4 \text { Bleeding in first } 24 \text { hours (adults } \\
\text { - } \mathrm{ml} \text {; neonates and paediatrics } \\
\mathrm{ml} / \mathrm{kg} \text { ) }\end{array}$ & 4 & & Mean Difference (IV, Random, 95\% CI) & Subtotals only \\
\hline 4.1 Neonates and paediatrics & 4 & 138 & Mean Difference (IV, Random, 95\% CI) & $-1.46[-4.70,1.78]$ \\
\hline $\begin{array}{l}5 \text { Transfusion requirements } \\
\text { (volume) - red cells (up to } 24 \\
\text { hours) (adults - } \mathrm{ml} \text {; neonates } \\
\text { and paediatrics } \mathrm{ml} / \mathrm{kg} \text { ) }\end{array}$ & 3 & & Mean Difference (IV, Random, 95\% CI) & Subtotals only \\
\hline 5.1 Neonates and paediatrics & 3 & 110 & Mean Difference (IV, Random, 95\% CI) & $0.40[-2.99,3.79]$ \\
\hline $\begin{array}{l}6 \text { Number of patients receiving a } \\
\text { red cell transfusion }\end{array}$ & 4 & 222 & Peto Odds Ratio (Peto, Fixed, 95\% CI) & $2.57[1.30,5.08]$ \\
\hline $\begin{array}{l}7 \text { Transfusion requirements - } \\
\text { platelets (up to } 24 \text { hours) } \\
\text { (units) }\end{array}$ & 2 & & Mean Difference (IV, Random, 95\% CI) & Totals not selected \\
\hline 7.1 Neonates and paediatrics & 2 & & Mean Difference (IV, Random, 95\% CI) & $0.0[0.0,0.0]$ \\
\hline $\begin{array}{l}8 \text { Transfusion requirements - } \\
\text { cryoprecipitate (up to } 24 \\
\text { hours) (units) }\end{array}$ & 2 & & Mean Difference (IV, Random, 95\% CI) & Totals not selected \\
\hline 8.1 Neonates and paediatrics & 2 & & Mean Difference (IV, Random, 95\% CI) & $0.0[0.0,0.0]$ \\
\hline $\begin{array}{l}9 \text { Measurement of prothrombin } \\
\text { time within } 2 \text { hours of FFP or } \\
\text { control infusion }\end{array}$ & 5 & 210 & Mean Difference (IV, Fixed, 95\% CI) & $-0.71[-1.28,-0.13]$ \\
\hline $\begin{array}{l}10 \text { Measurement of activated } \\
\text { partial thromboplastin time } \\
\text { within } 2 \text { hours of FFP or } \\
\text { control infusion }\end{array}$ & 8 & & Mean Difference (IV, Random, 95\% CI) & Totals not selected \\
\hline $\begin{array}{l}11 \text { Measurement of fibrinogen } \\
\text { concentration within } 2 \text { hours } \\
\text { of FFP or control infusion }\end{array}$ & 5 & & Mean Difference (IV, Random, 95\% CI) & Totals not selected \\
\hline $\begin{array}{l}12 \text { Resource use: time in intensive } \\
\text { care unit }\end{array}$ & 2 & & Mean Difference (IV, Random, 95\% CI) & Totals not selected \\
\hline $\begin{array}{l}13 \text { Resource use: need for return } \\
\text { to theatre }\end{array}$ & 7 & 398 & Peto Odds Ratio (Peto, Fixed, 95\% CI) & $0.81[0.26,2.57]$ \\
\hline
\end{tabular}

Fresh frozen plasma for cardiovascular surgery (Review) 
Analysis I.I. Comparison I Fresh frozen plasma versus no plasma, Outcome I Short-term mortality (up to 30 days).

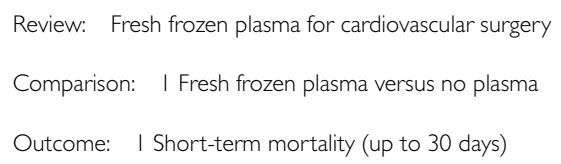

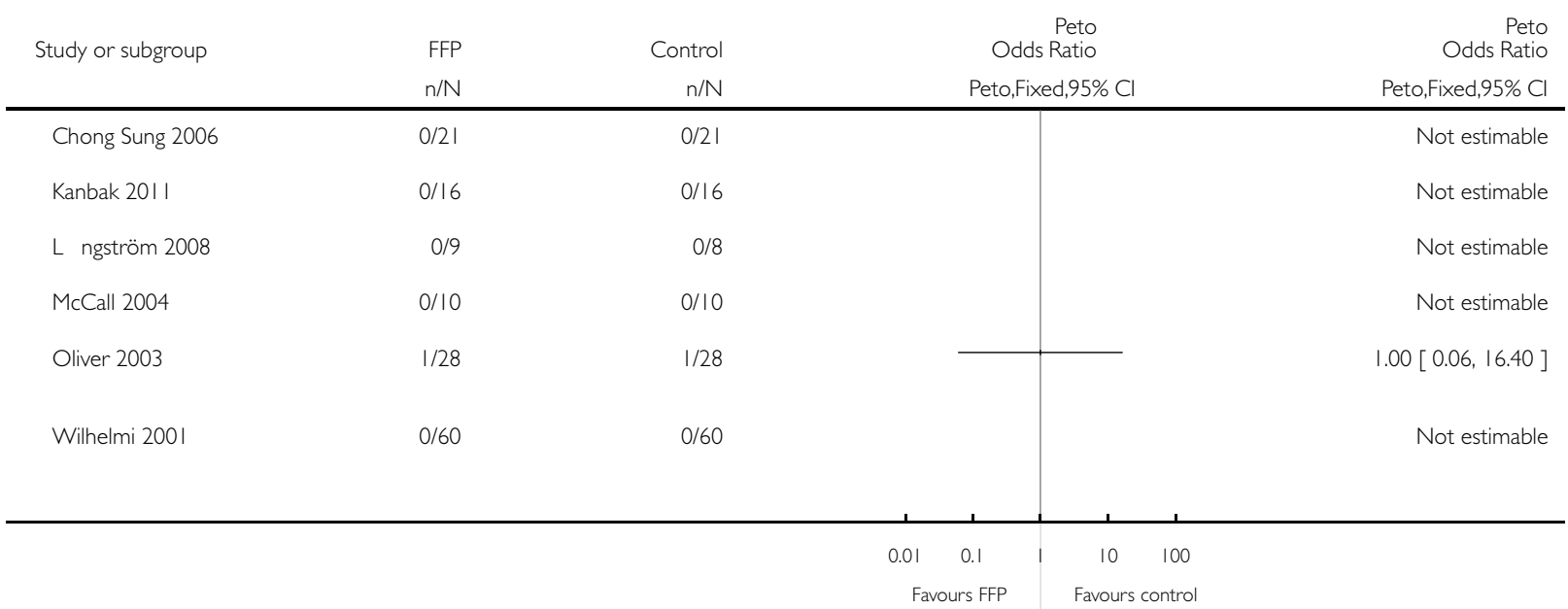


Analysis I.2. Comparison I Fresh frozen plasma versus no plasma, Outcome 2 Serious organ damage myocardial infarction.

Review: Fresh frozen plasma for cardiovascular surgery

Comparison: I Fresh frozen plasma versus no plasma

Outcome: 2 Serious organ damage - myocardial infarction

Control

$n / \mathrm{N} \quad \mathrm{n} / \mathrm{N}$

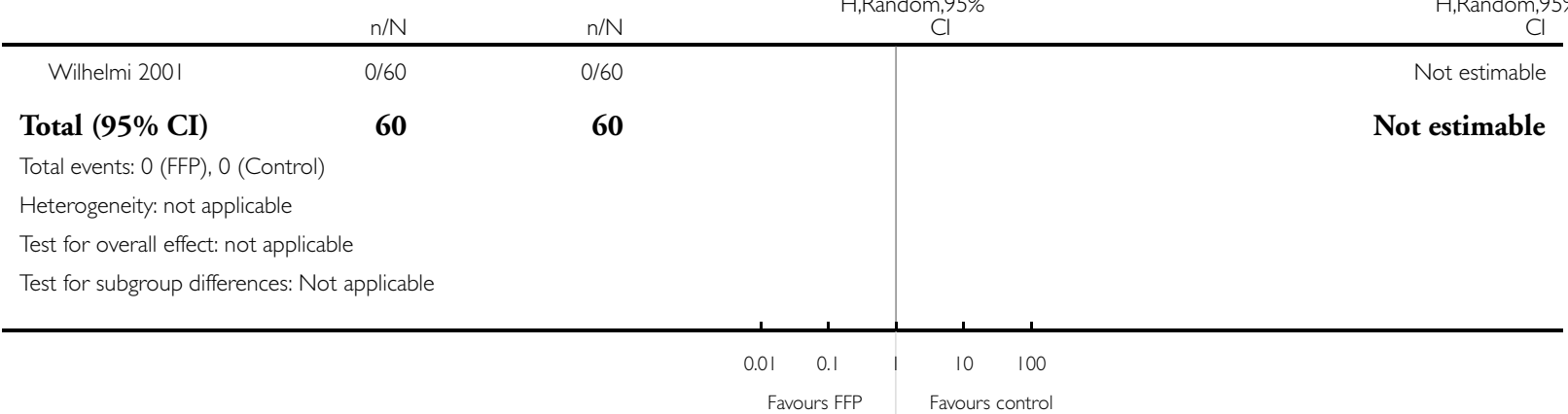

Analysis I.3. Comparison I Fresh frozen plasma versus no plasma, Outcome 3 Serious organ damage renal failure.

Review: Fresh frozen plasma for cardiovascular surgery

Comparison: I Fresh frozen plasma versus no plasma

Outcome: 3 Serious organ damage - renal failure

\begin{tabular}{|c|c|c|c|c|c|c|c|c|c|}
\hline \multirow[t]{2}{*}{ Study or subgroup } & \multirow{2}{*}{$\begin{array}{l}\text { FFP } \\
\mathrm{N}\end{array}$} & \multicolumn{3}{|c|}{ Control } & \multicolumn{4}{|c|}{$\begin{array}{r}\text { Mean } \\
\text { Difference }\end{array}$} & $\begin{array}{r}\text { Mean } \\
\text { Difference }\end{array}$ \\
\hline & & Mean(SD) & $N$ & Mean(SD) & \multicolumn{4}{|c|}{ IV,Random,95\% Cl } & IV,Random,95\% Cl \\
\hline \multirow[t]{2}{*}{ Loeffelbein 2008} & 10 & $41.3(4.3)$ & 10 & $89.6(66.7)$ & & & & & $-48.30[-89.73,-6.87]$ \\
\hline & & & & & -100 & -50 & 50 & 100 & \\
\hline
\end{tabular}


Analysis I.4. Comparison I Fresh frozen plasma versus no plasma, Outcome 4 Bleeding in first 24 hours (adults - $\mathrm{ml}$; neonates and paediatrics $\mathrm{ml} / \mathrm{kg}$ ).

Review: Fresh frozen plasma for cardiovascular surgery

Comparison: I Fresh frozen plasma versus no plasma

Outcome: 4 Bleeding in first 24 hours (adults - $\mathrm{ml}$; neonates and paediatrics $\mathrm{ml} / \mathrm{kg}$ )

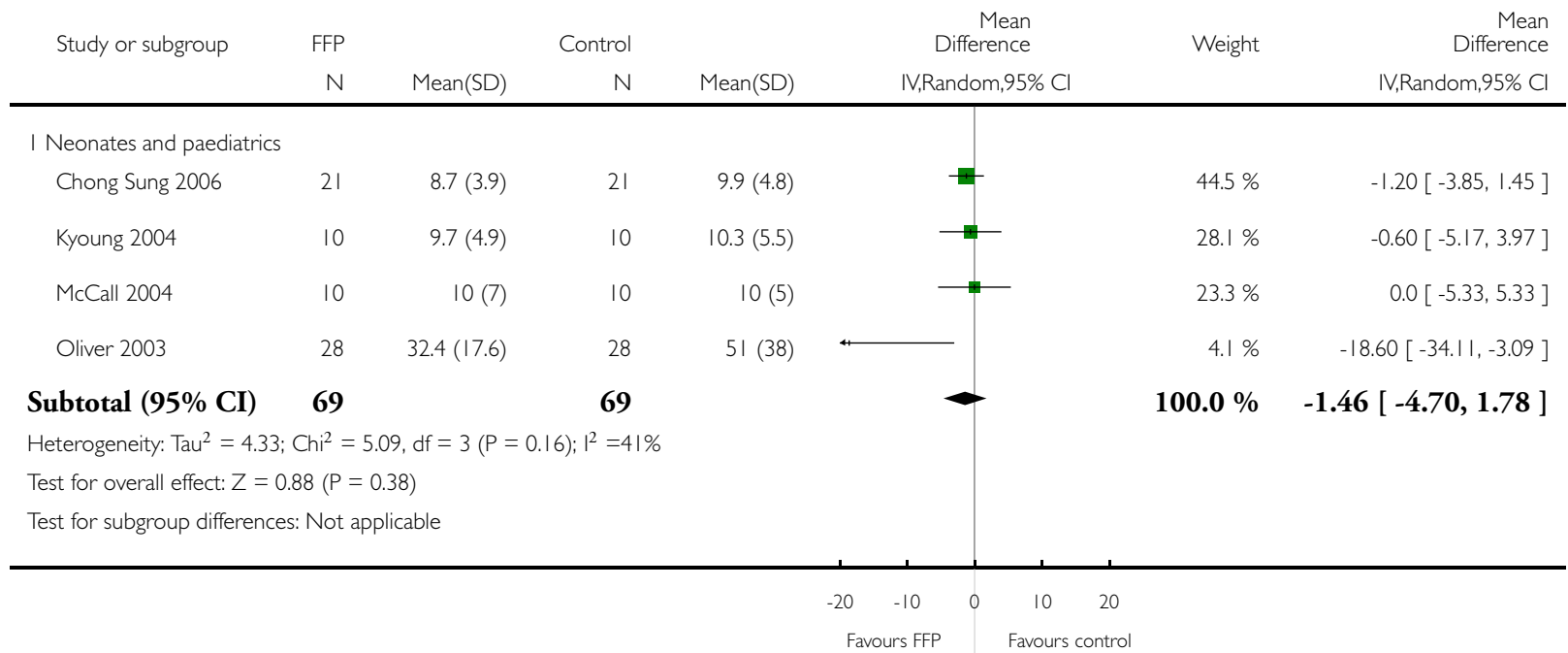


Analysis I.5. Comparison I Fresh frozen plasma versus no plasma, Outcome 5 Transfusion requirements (volume) - red cells (up to 24 hours) (adults - $\mathrm{ml}$; neonates and paediatrics $\mathrm{ml} / \mathrm{kg}$ ).

Review: Fresh frozen plasma for cardiovascular surgery

Comparison: I Fresh frozen plasma versus no plasma

Outcome: 5 Transfusion requirements (volume) - red cells (up to 24 hours) (adults - $\mathrm{ml}$; neonates and paediatrics $\mathrm{ml} / \mathrm{kg}$ )

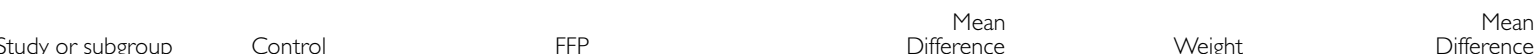

N Mean(SD) N $\quad$ Mean(SD) IV,Random,95\% Cl IV,Random,95\% Cl

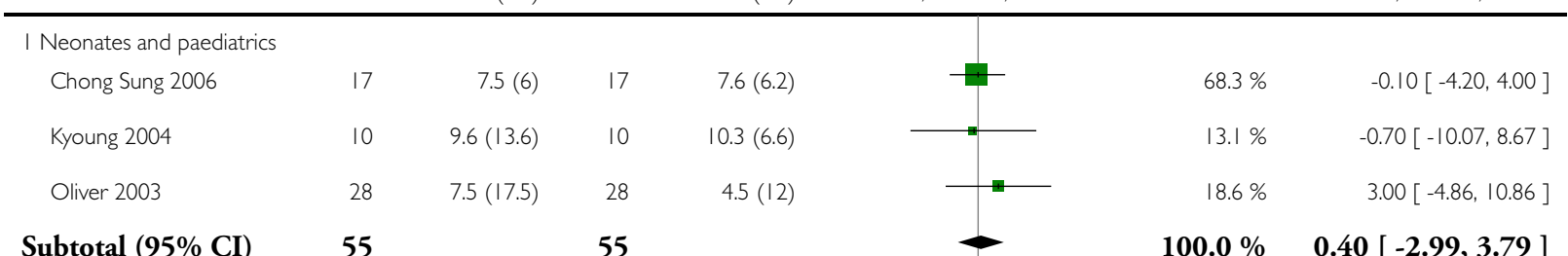

Subtotal $(95 \%$ CI $) \quad 55$

Heterogeneity: $\operatorname{Tau}^{2}=0.0 ; \mathrm{Chi}^{2}=0.53, \mathrm{df}=2(\mathrm{P}=0.77) ;\left.\right|^{2}=0.0 \%$

Test for overall effect: $Z=0.23(P=0.82)$

Test for subgroup differences: Not applicable 
Analysis I.6. Comparison I Fresh frozen plasma versus no plasma, Outcome 6 Number of patients receiving a red cell transfusion.

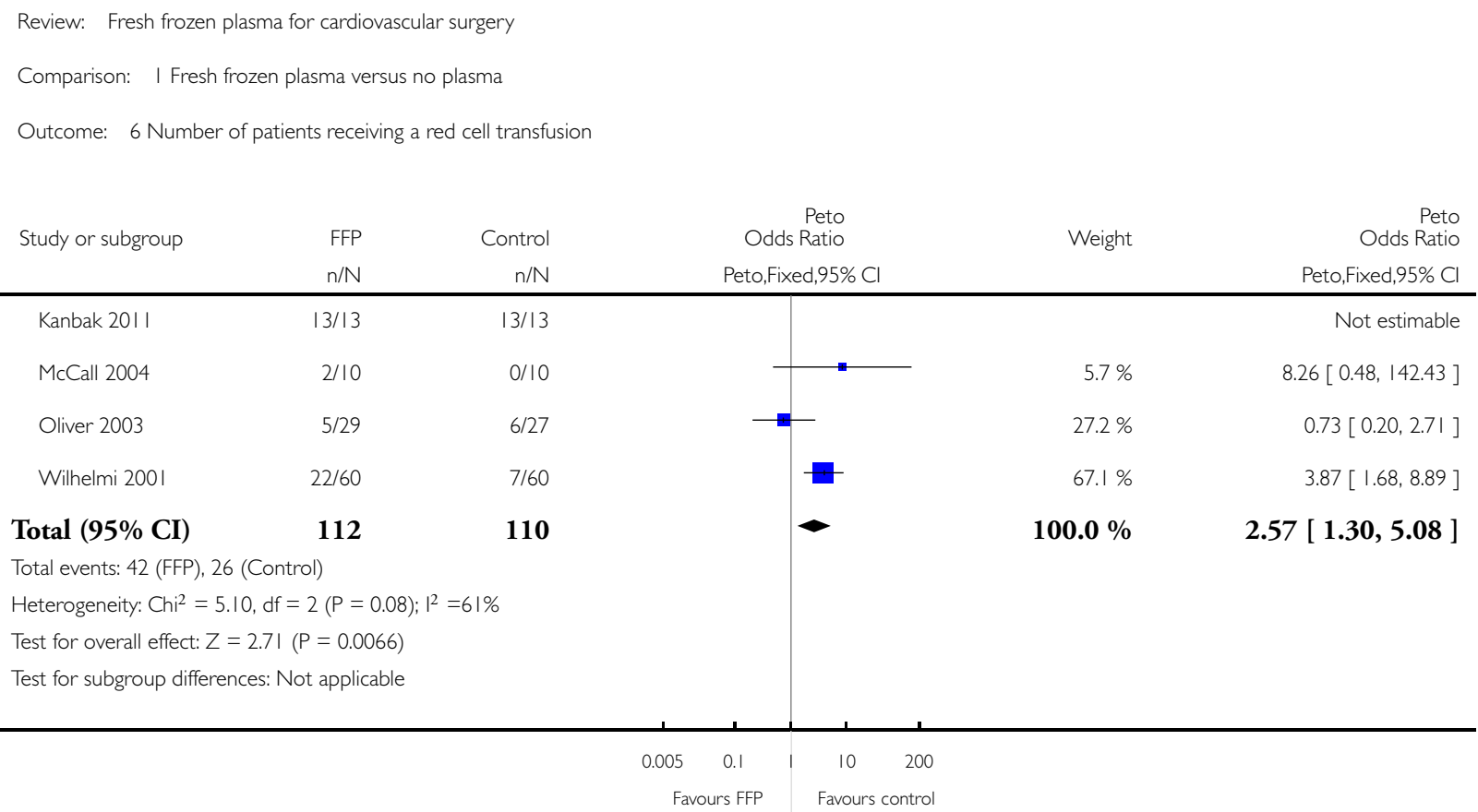

\section{Analysis I.7. Comparison I Fresh frozen plasma versus no plasma, Outcome 7 Transfusion requirements -} platelets (up to 24 hours) (units).

Review: Fresh frozen plasma for cardiovascular surgery

Comparison: I Fresh frozen plasma versus no plasma

Outcome: 7 Transfusion requirements - platelets (up to 24 hours) (units)

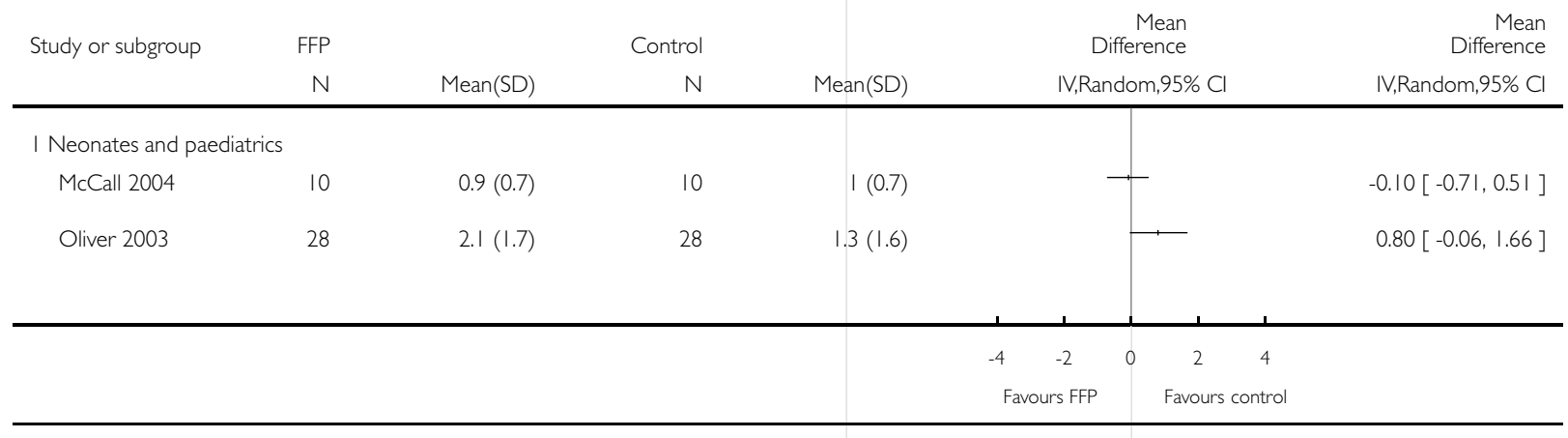

Fresh frozen plasma for cardiovascular surgery (Review)

Copyright $\odot 2015$ The Cochrane Collaboration. Published by John Wiley \& Sons, Ltd. 
Analysis I.8. Comparison I Fresh frozen plasma versus no plasma, Outcome 8 Transfusion requirements cryoprecipitate (up to 24 hours) (units).

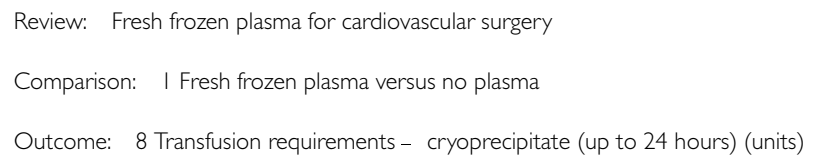

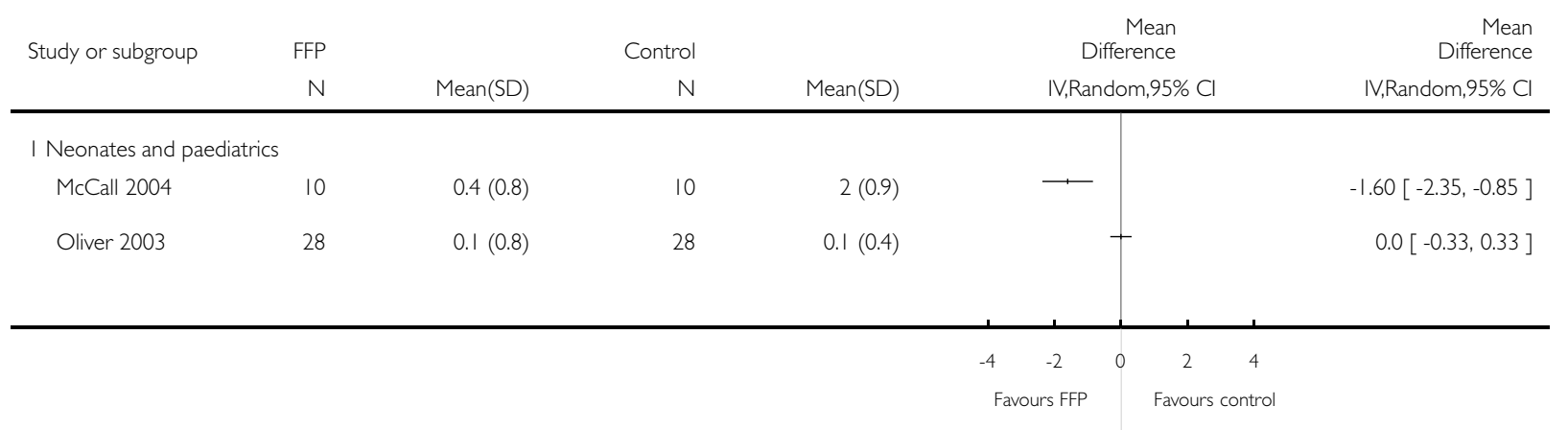


Analysis I.9. Comparison I Fresh frozen plasma versus no plasma, Outcome 9 Measurement of prothrombin time within 2 hours of FFP or control infusion.

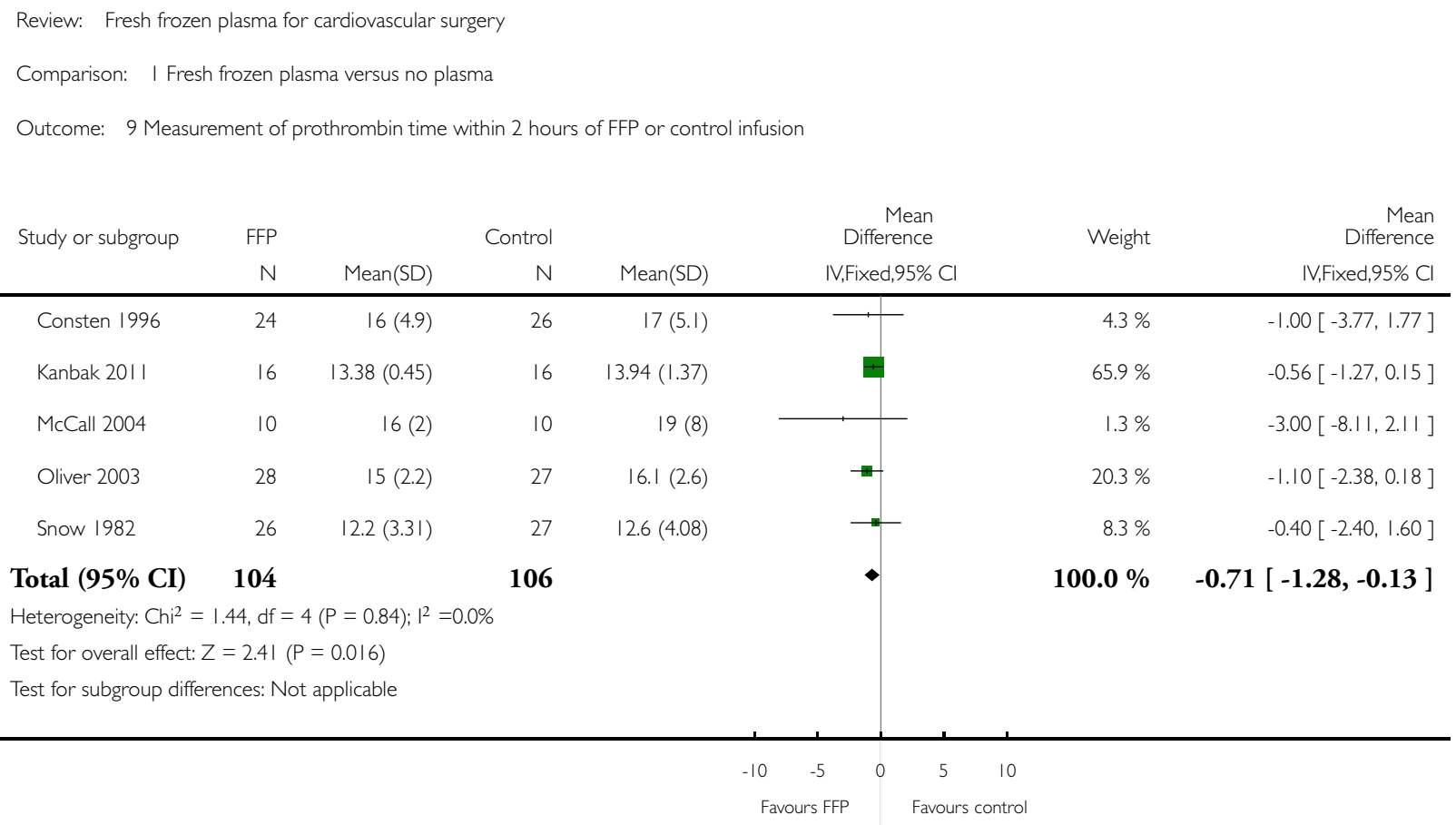


Analysis I.10. Comparison I Fresh frozen plasma versus no plasma, Outcome I0 Measurement of activated partial thromboplastin time within 2 hours of FFP or control infusion.

Review: Fresh frozen plasma for cardiovascular surgery

Comparison: I Fresh frozen plasma versus no plasma

Outcome: 10 Measurement of activated partial thromboplastin time within 2 hours of FFP or control infusion

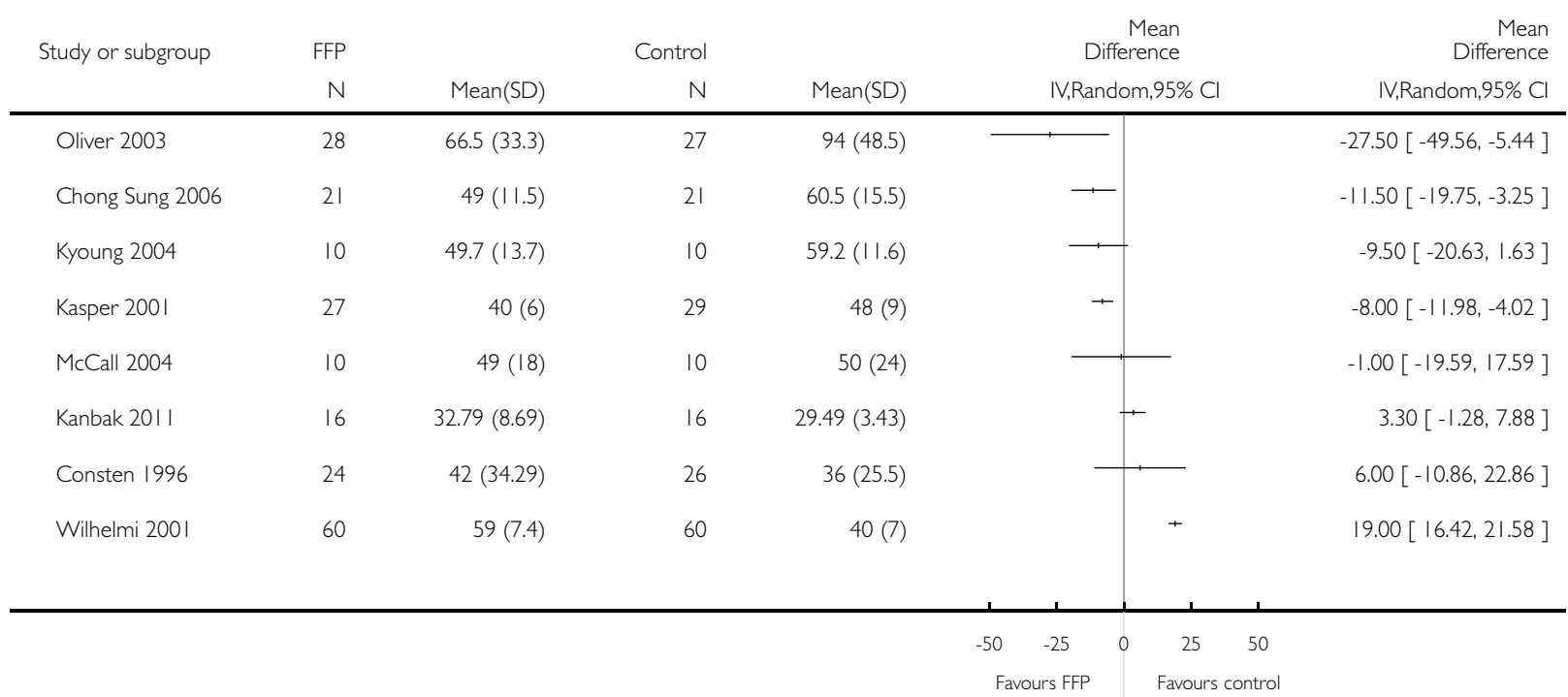


Analysis I.II. Comparison I Fresh frozen plasma versus no plasma, Outcome I I Measurement of fibrinogen concentration within 2 hours of FFP or control infusion.

Review: Fresh frozen plasma for cardiovascular surgery

Comparison: I Fresh frozen plasma versus no plasma

Outcome: II Measurement of fibrinogen concentration within 2 hours of FFP or control infusion

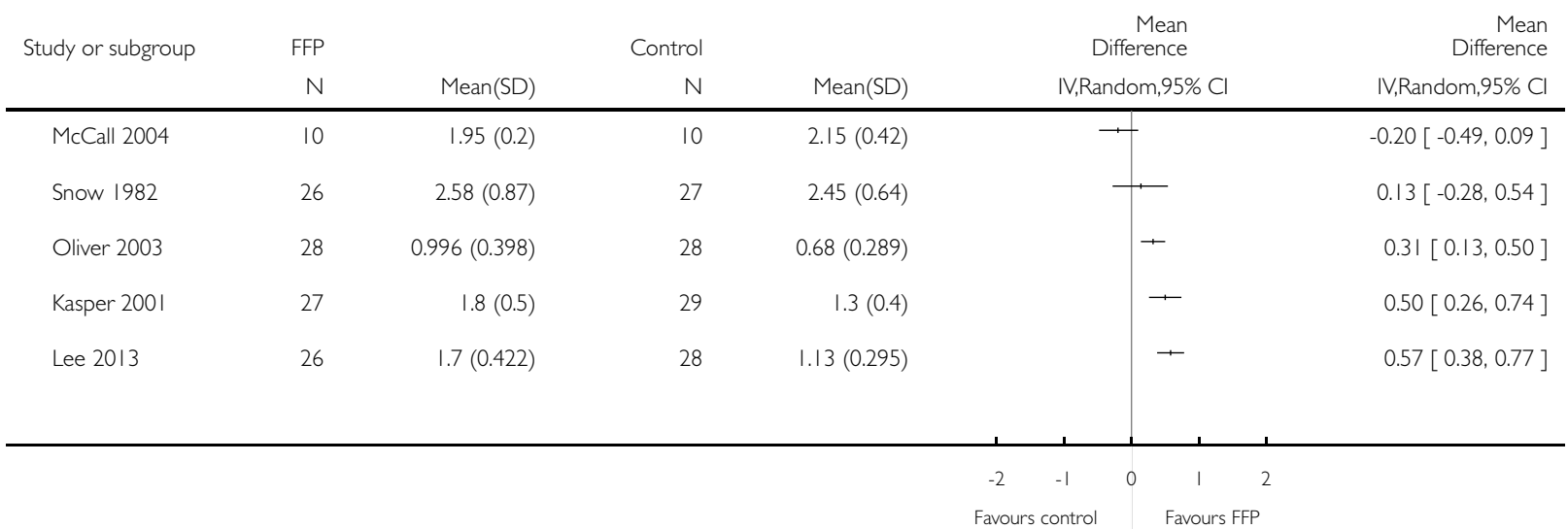

Analysis I.I2. Comparison I Fresh frozen plasma versus no plasma, Outcome I2 Resource use: time in intensive care unit.

Review: Fresh frozen plasma for cardiovascular surgery

Comparison: I Fresh frozen plasma versus no plasma

Outcome: 12 Resource use: time in intensive care unit

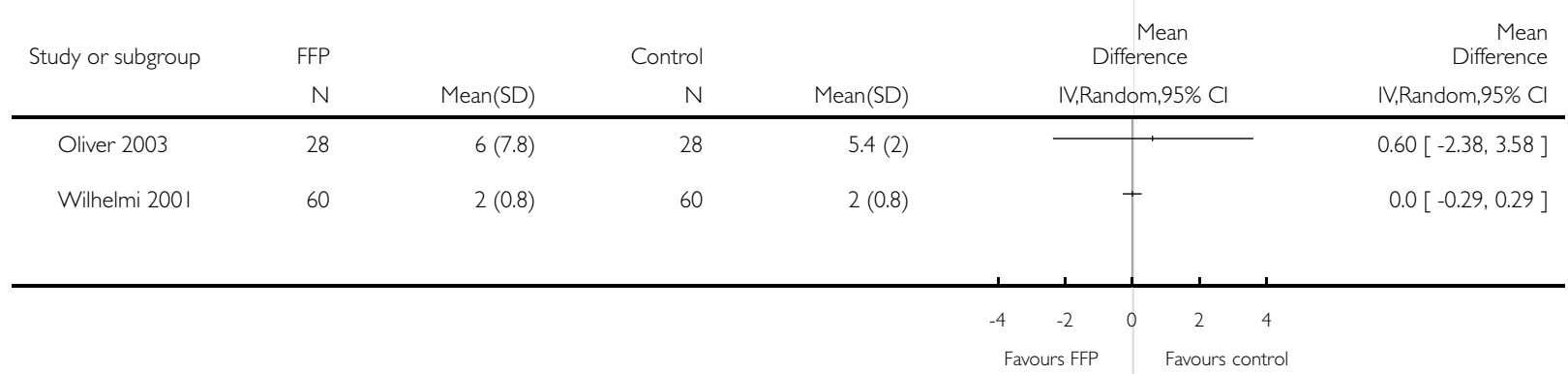


Analysis I.13. Comparison I Fresh frozen plasma versus no plasma, Outcome I3 Resource use: need for return to theatre.

Review: Fresh frozen plasma for cardiovascular surgery

Comparison: I Fresh frozen plasma versus no plasma

Outcome: 13 Resource use: need for return to theatre

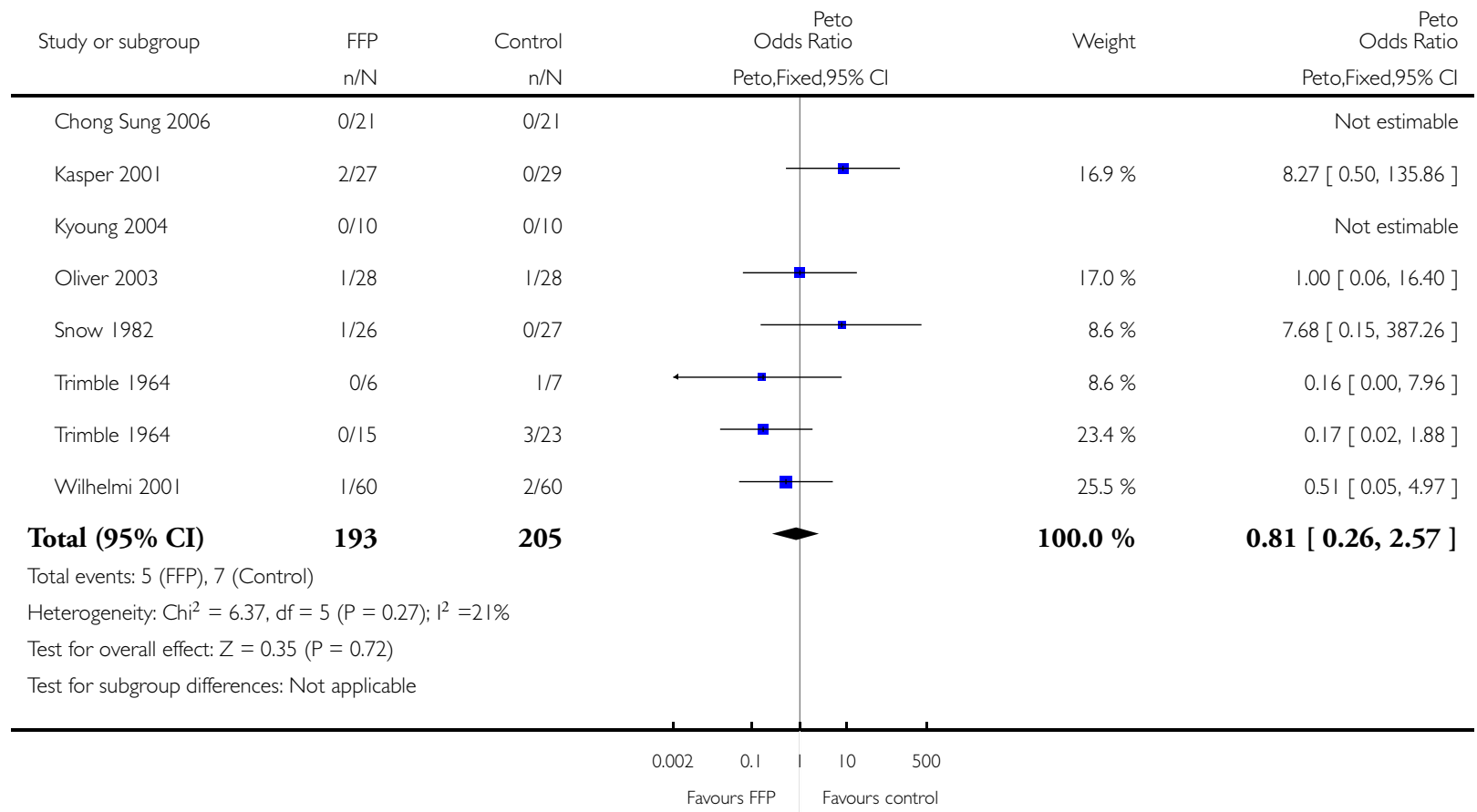

\section{ADDITIONAL TABLES}

Table 1. Blood loss

FFP

Comparator

Blood loss at 24 hours: data reported as median values (with 25 and 75 percentiles)

\begin{tabular}{l|l|l}
\hline Kasper 2001 - adults & $\begin{array}{l}630 \mathrm{ml}(450 \text { to } 1840) \\
(\mathrm{n}=24)\end{array}$ & $\begin{array}{l}830 \mathrm{ml}(340 \text { to 1980) } \\
\text { (n=28) }\end{array}$ \\
\hline $\begin{array}{l}\text { Lee } 2013 \text { - infants (aged less than } 12 \\
\text { months) }\end{array}$ & $\begin{array}{l}10.3 \mathrm{ml} / \mathrm{kg}(7.4 \text { to } 17.3) \\
(\mathrm{n}=26)\end{array}$ & $\begin{array}{l}10 \mathrm{ml} / \mathrm{kg}(6.9 \text { to } 22.5) \\
\text { (n=28) }\end{array}$ \\
\hline Lee 2013 - children (aged 1 to 16 years) & $\begin{array}{l}11.5 \mathrm{ml} / \mathrm{kg}(6.4 \text { to } 19.1) \\
(\mathrm{n}=34)\end{array}$ & $\begin{array}{l}12.2 \mathrm{ml} / \mathrm{kg}(6.9 \text { to } 28.5) \\
\text { (n=33) }\end{array}$ \\
\hline $\begin{array}{l}\text { Fresh frozen plasma for cardiovascular surgery (Review) } \\
\text { Copyright } \odot 2015 \text { The Cochrane Collaboration. Published by John Wiley \& Sons, Ltd. }\end{array}$ & \\
\hline
\end{tabular}

Copyright $\odot 2015$ The Cochrane Collaboration. Published by John Wiley \& Sons, Ltd. 


\section{Blood loss: timing of measurement not reported}

\begin{tabular}{lll}
\hline $\begin{array}{l}\text { Consten } 1996 \text { - during postoperative ICU } \\
\text { admission* }\end{array}$ & $\begin{array}{l}896(104) \mathrm{ml} \\
(\mathrm{n}=24)\end{array}$ & $\begin{array}{l}776(76) \mathrm{ml} \\
(\mathrm{n}=26)\end{array}$ \\
\hline $\begin{array}{l}\text { Kanbak } 2011 \text { - during postoperative ICU } \\
\text { admission* }\end{array}$ & $\begin{array}{l}979(497) \mathrm{ml} \\
(\mathrm{n}=16)\end{array}$ & $\begin{array}{l}1022(424) \mathrm{ml} \\
(\mathrm{n}=16)\end{array}$ \\
\hline $\begin{array}{l}\text { Snow } 1982 \text { - during postoperative ICU ad- } \\
\text { mission. Bleeding from 2 separate chest } \\
\text { drains reported independently* }\end{array}$ & $\begin{array}{l}\text { Chest drain 1: } 676(449) \mathrm{ml} \\
(\mathrm{n}=26)\end{array}$ & $\begin{array}{l}\text { Chest drain } 1: 531(286) \mathrm{ml} \\
\text { Chest drain 2: } 211(155) \mathrm{ml} \\
(\mathrm{n}=27)\end{array}$ \\
\hline $\begin{array}{l}\text { Trimble } 1964 \text { - children** } \\
\text { Che }\end{array}$ & $\begin{array}{l}120 \mathrm{ml} \\
(\mathrm{n}=7)\end{array}$ & $\begin{array}{l}135 \mathrm{ml} \\
(\mathrm{n}=6)\end{array}$ \\
\hline $\begin{array}{l}\text { Trimble } 1964 \text { - adults } \\
* *\end{array}$ & $\begin{array}{l}400 \mathrm{ml} \\
(\mathrm{n}=15)\end{array}$ & $\begin{array}{l}500 \mathrm{ml} \\
(\mathrm{n}=23)\end{array}$ \\
\hline
\end{tabular}

* Data reported as mean values (with standard deviation).

** Data reported as mean values: no standard deviations reported and these data not sought due to the age of the trial.

FFP: fresh frozen plasma

ICU: intensive care unit

Table 2. Transfusion requirements: red blood cells

\begin{tabular}{|c|c|c|}
\hline & FFP & Comparator \\
\hline $\begin{array}{l}\text { Consten } 1996 \text { - red blood cell volume } \\
\text { transfused during 24-hour postoperative } \\
\text { ICU admission* }\end{array}$ & $\begin{array}{l}608(152) \mathrm{ml} \\
(\mathrm{n}=24)\end{array}$ & $\begin{array}{l}756(79) \mathrm{ml} \\
(\mathrm{n}=26)\end{array}$ \\
\hline $\begin{array}{l}\text { Kasper } 2001 \text { - red blood cell transfusion } \\
\text { requirements at } 24 \text { hours: adults }{ }^{* *}\end{array}$ & $\begin{array}{l}1 \text { unit red cells (range } 0 \text { to } 3 \text { units) } \\
(\mathrm{n}=24)\end{array}$ & $\begin{array}{l}3 \text { units red cells (range } 0 \text { to } 6 \text { units) } \\
(\mathrm{n}=28)\end{array}$ \\
\hline $\begin{array}{l}\text { Lee } 2013 \text { - red blood cell transfusion re- } \\
\text { quirements at } 24 \text { hours in ICU: infants } \\
\text { (aged less than } 12 \text { months)** }\end{array}$ & $\begin{array}{l}5 \mathrm{ml}(0 \text { to } 42.5) \\
(\mathrm{n}=26)\end{array}$ & $\begin{array}{l}12.5 \mathrm{ml}(0 \text { to } 66.8) \\
(\mathrm{n}=28)\end{array}$ \\
\hline $\begin{array}{l}\text { Lee } 2013 \text { - red blood cell transfusion re- } \\
\text { quirements at } 24 \text { hours in ICU: children } \\
\text { (aged } 1 \text { to } 16 \text { years) }^{* *}\end{array}$ & $\begin{array}{l}0 \mathrm{ml}(0 \text { to } 120) \\
(\mathrm{n}=34)\end{array}$ & $\begin{array}{l}0 \mathrm{ml}(0 \text { to } 125) \\
(\mathrm{n}=33)\end{array}$ \\
\hline $\begin{array}{l}\text { Wilhelmi } 2001 \text { - number of units of red } \\
\text { blood cells transfused per patient in the first } \\
24 \text { hours* }\end{array}$ & $\begin{array}{l}1.6(2) \text { units/patient } \\
(\mathrm{n}=60)\end{array}$ & $\begin{array}{l}0.6(1) \text { units/patient } \\
(\mathrm{n}=60)\end{array}$ \\
\hline
\end{tabular}


Table 2. Transfusion requirements: red blood cells (Continued)

Snow 1982 - number of units of red blood 3.00 (1.68) units/patient

2.68 (1.67) units/patient

cells transfused per patient over admission* $\quad(n=26)$

$(\mathrm{n}=27)$

* Data reported as mean values (with standard deviation).

** Data reported as median values (with 25 and 75 percentiles).

FFP: fresh frozen plasma

ICU: intensive care unit

Table 3. Transfusion requirement: platelet usage

\begin{tabular}{|c|c|c|}
\hline & FFP & Comparator \\
\hline $\begin{array}{l}\text { Lee } 2013 \text { - platelet transfusion require- } \\
\text { ments at } 24 \text { hours in ICU: infants (aged } \\
\text { less than } 12 \text { months)* }\end{array}$ & $\begin{array}{l}0 \mathrm{ml}(0 \text { to } 31.3) \\
(\mathrm{n}=26)\end{array}$ & $\begin{array}{l}0 \mathrm{ml}(0 \text { to } 36) \\
(\mathrm{n}=28)\end{array}$ \\
\hline $\begin{array}{l}\text { Lee } 2013 \text { - platelet transfusion require- } \\
\text { ments at } 24 \text { hours in ICU: children (aged } \\
1 \text { to } 16 \text { years)* }\end{array}$ & $\begin{array}{l}0 \mathrm{ml}(0 \text { to } 20) \\
(\mathrm{n}=34)\end{array}$ & $\begin{array}{l}0 \mathrm{ml}(0 \text { to } 30) \\
(\mathrm{n}=33)\end{array}$ \\
\hline $\begin{array}{l}\text { McCall } 2004 \text { - number of donor exposures } \\
\text { from platelets, per patient** }\end{array}$ & $\begin{array}{l}0.9(0.7) \\
(\mathrm{n}=10)\end{array}$ & $\begin{array}{l}1(0.7) \\
(\mathrm{n}=10)\end{array}$ \\
\hline $\begin{array}{l}\text { Oliver } 2003 \text { - platelet units transfused in } \\
\text { the operating theatre and during the first } \\
24 \text { hours in ICU }{ }^{* *}\end{array}$ & $\begin{array}{l}2.1(1.7) \\
(\mathrm{n}=28)\end{array}$ & $\begin{array}{l}1.3(1.6) \\
(\mathrm{n}=28)\end{array}$ \\
\hline
\end{tabular}

${ }^{*}$ Data reported as median values (with 25 and 75 percentiles).

**Data reported as mean values (with standard deviation).

FFP: fresh frozen plasma

ICU: intensive care unit

Table 4. Transfusion requirements: cryoprecipitate

\begin{tabular}{lll}
\hline & FFP & Comparator \\
\hline $\begin{array}{l}\text { McCall 2004 - number of donor exposures } \\
\text { from cryoprecipitate per patient }\end{array}$ & $\begin{array}{l}0.4 \text { units } \pm 0.8 \text { units } \\
(\mathrm{n}=10)\end{array}$ & $\begin{array}{l}2.0 \text { units } \pm 0.9 \text { units } \\
(\mathrm{n}=10)\end{array}$ \\
\hline $\begin{array}{l}\text { Oliver } 2003 \text { - number of cryoprecipitate } \\
\text { units transfused in the operating theatre } \\
\text { and during the first } 24 \text { hours in ICU }\end{array}$ & $\begin{array}{l}0.1 \text { units } \pm 0.8 \text { units } \\
(\mathrm{n}=28)\end{array}$ & $\begin{array}{l}0.1 \text { units } \pm 0.4 \text { units } \\
(\mathrm{n}=28)\end{array}$ \\
\hline
\end{tabular}

Data expressed as mean \pm standard deviation.

FFP: fresh frozen plasma

ICU: intensive care unit 
Table 5. Measurement of coagulation: prothrombin time (PT)

\begin{tabular}{l|ll}
\hline & FFP & Comparator \\
\hline $\begin{array}{l}\text { Kasper } 2001 \text { - percentage of expected pro- } \\
\text { thrombin time after FFP (or comparator) } \\
\text { infusion* }\end{array}$ & $\begin{array}{l}58 \% \pm 10 \% \\
(\mathrm{n}=27)\end{array}$ & $\begin{array}{l}46 \% \pm 8 \% \\
(\mathrm{n}=29)\end{array}$ \\
\hline $\begin{array}{l}\text { Kyoung } 2004-\text { international normalised } \\
\text { ratio at end of surgery* }\end{array}$ & $\begin{array}{l}1.44 \pm 0.13 \\
(\mathrm{n}=10)\end{array}$ & $\begin{array}{l}2.01 \pm 0.42 \\
(\mathrm{n}=10)\end{array}$ \\
\hline $\begin{array}{l}\text { Lee } 2013-\text { prothrombin time after } 24 \\
\text { hours in ICU: infants* }\end{array}$ & $\begin{array}{l}15.3 \text { seconds }(14 \text { to } 16.1 \text { seconds) } \\
(\mathrm{n}=26)\end{array}$ & $\begin{array}{l}14.8 \text { seconds }(13.7 \text { to } 16.6 \text { seconds) } \\
(\mathrm{n}=28)\end{array}$ \\
\hline $\begin{array}{l}\text { Lee } 2013-\text { prothrombin time after } 24 \\
\text { hours in ICU: children (aged } 1 \text { to } 16 \text { years) } \\
*\end{array}$ & $\begin{array}{l}15 \text { seconds } \pm 1.7 \text { seconds } \\
(\mathrm{n}=34)\end{array}$ & $\begin{array}{l}15 \text { seconds } \pm 1.9 \text { seconds } \\
(\mathrm{n}=33)\end{array}$ \\
\hline $\begin{array}{l}\text { Wilhelmi } 2001 \text { - percentage of expected } \\
\text { prothrombin time after admission to ICU* }\end{array}$ & $\begin{array}{l}79 \% \pm 9.3 \% \\
(\mathrm{n}=60)\end{array}$ & $\begin{array}{l}74 \% \pm 10.1 \% \\
(\mathrm{n}=60)\end{array}$ \\
\hline
\end{tabular}

*Data reported as mean \pm standard deviation.

**Data reported as median (interquartile range).

FFP: fresh frozen plasma

ICU: intensive care unit

Table 6. Measurement of coagulation factors or tests: APTT

\begin{tabular}{|c|c|c|}
\hline & FFP & Comparator \\
\hline $\begin{array}{l}\text { Lee } 2013 \text { - APTT level at } 24 \text { hours in ICU: } \\
\text { infants (aged less than } 12 \text { months)* }\end{array}$ & $\begin{array}{l}34.4 \operatorname{secs}(32.4 \text { to } 42.5) \\
(\mathrm{n}=26)\end{array}$ & $\begin{array}{l}39 \operatorname{secs}(34.7 \text { to } 47.4) \\
(\mathrm{n}=28)\end{array}$ \\
\hline $\begin{array}{l}\text { Lee } 2013 \text { - APTT level at } 24 \text { hours in ICU: } \\
\text { children (aged } 1 \text { to } 16 \text { years)* }\end{array}$ & $\begin{array}{l}31.8 \text { secs }(29.5 \text { to } 33.8) \\
(\mathrm{n}=34)\end{array}$ & $\begin{array}{l}32.5 \operatorname{secs}(29.4 \text { to } 34.8) \\
(\mathrm{n}=33)\end{array}$ \\
\hline
\end{tabular}

*Data reported as median values (with 25 and 75 percentiles).

APTT: activated partial thromboplastin time

FFP: fresh frozen plasma

ICU: intensive care unit

Table 7. Measures of coagulation: fibrinogen concentration

\begin{tabular}{|c|c|c|c|}
\hline & FFP & Comparator & \\
\hline $\begin{array}{l}\text { Kasper } 2001 \text { - fibrinogen concentration af- } \\
\text { ter FFP (or comparator) infusion* }\end{array}$ & $\begin{array}{l}1.8 \mathrm{~g} / \mathrm{l} \pm 0.5 \mathrm{~g} / \mathrm{l} \\
(\mathrm{n}=27)\end{array}$ & $\begin{array}{l}1.3 \mathrm{~g} / 1 \pm 0.4 \mathrm{~g} / \mathrm{l} \\
(\mathrm{n}=29)\end{array}$ & \\
\hline
\end{tabular}


Table 7. Measures of coagulation: fibrinogen concentration (Continued)

\begin{tabular}{|c|c|c|}
\hline $\begin{array}{l}\text { Lee } 2013 \text { - fibrinogen concentration after } \\
\text { protamine administration: infants* }\end{array}$ & $\begin{array}{l}1.70 \mathrm{~g} / 1 \pm 0.422 \mathrm{~g} / \mathrm{l} \\
(\mathrm{n}=26)\end{array}$ & $\begin{array}{l}1.129 \mathrm{~g} / \mathrm{l} \pm 0.295 \mathrm{~g} / \mathrm{l} \\
(\mathrm{n}=28)\end{array}$ \\
\hline $\begin{array}{l}\text { Lee } 2013 \text { - fibrinogen concentration after } \\
\text { protamine administration: children (aged } \\
1 \text { to } 16 \text { years) }{ }^{* *}\end{array}$ & $\begin{array}{l}1.54 \mathrm{~g} / \mathrm{l}(1.388 \text { to } 1.933 \mathrm{~g} / \mathrm{l}) \\
(\mathrm{n}=34)\end{array}$ & $\begin{array}{l}1.36 \mathrm{~g} / \mathrm{l}(1.163 \text { to } 1.583 \mathrm{~g} / \mathrm{l}) \\
(\mathrm{n}=33)\end{array}$ \\
\hline $\begin{array}{l}\text { McCall } 2004 \text { - fibrinogen concentration af- } \\
\text { ter end of cardiopulmonary bypass* }\end{array}$ & $\begin{array}{l}1.23 \mathrm{~g} / 1 \pm 0.2 \mathrm{~g} / \mathrm{l} \\
(\mathrm{n}=10)\end{array}$ & $\begin{array}{l}0.58 \mathrm{~g} / \mathrm{l} \pm 0.17 \mathrm{~g} / \mathrm{l} \\
(\mathrm{n}=10)\end{array}$ \\
\hline $\begin{array}{l}\text { Oliver } 2003 \text { - fibrinogen concentration } 10 \\
\text { minutes after protamine administration* }\end{array}$ & $\begin{array}{l}0.996 \mathrm{~g} / \mathrm{l} \pm 0.398 \mathrm{~g} / \mathrm{l} \\
(\mathrm{n}=28)\end{array}$ & $\begin{array}{l}0.681 \mathrm{~g} / 1 \pm 0.289 \mathrm{~g} / \mathrm{l} \\
(\mathrm{n}=28)\end{array}$ \\
\hline $\begin{array}{l}\text { Snow } 1982 \text { - fibrinogen concentration in } \\
\text { recovery room postoperatively* }\end{array}$ & $\begin{array}{l}2.58 \mathrm{~g} / \mathrm{l} \pm 0.87 \mathrm{~g} / \mathrm{l} \\
(\mathrm{n}=26)\end{array}$ & $\begin{array}{l}2.45 \mathrm{~g} / \mathrm{l} \pm 0.64 \mathrm{~g} / \mathrm{l} \\
(\mathrm{n}=27)\end{array}$ \\
\hline
\end{tabular}

*Data reported as mean \pm standard deviation.

**Data reported as median (interquartile range).

FFP: fresh frozen plasma

Table 8. Tølløfsrud 2003: outcome data

\begin{tabular}{|c|c|c|c|}
\hline Outcome & $\begin{array}{l}\text { Uniplas (blood group A, B or } \\
\text { AB) } \\
(n=25)\end{array}$ & $\begin{array}{l}\text { Uniplas (blood group } O) \\
(n=11)\end{array}$ & $\begin{array}{l}\text { Octaplas (any blood group) } \\
(\mathbf{n}=19)\end{array}$ \\
\hline Short-term mortality (n) & 0 & 0 & 2 \\
\hline $\begin{array}{l}\text { Major complications: respira- } \\
\text { tory failure }(n)\end{array}$ & 2 & 0 & 0 \\
\hline $\begin{array}{l}\text { Major complications: myocar- } \\
\text { dial infarction }(n)\end{array}$ & 0 & 0 & 1 \\
\hline Major complications: stroke (n) & 2 & 1 & 0 \\
\hline $\begin{array}{l}\text { Major complications: renal fail- } \\
\text { ure (n) }\end{array}$ & 1 & 0 & 1 \\
\hline $\begin{array}{l}\text { Bleeding in first } 24 \text { hours: mean } \\
\pm \text { SD }\end{array}$ & $854(544) \mathrm{ml}$ & $946(943) \mathrm{ml}$ & $993(693) \mathrm{ml}$ \\
\hline Red cell transfusions (mean) & 3.7 units & 3.9 units & 3.2 units \\
\hline Platelet transfusions (mean) & 0.48 units & 0.36 units & 0.42 units \\
\hline
\end{tabular}


Table 8. Tølløfsrud 2003: outcome data (Continued)

\begin{tabular}{l|l|l|l}
\hline $\begin{array}{l}\text { Activated partial thromboplas- } \\
\text { tin time: mean } \pm \text { SD }\end{array}$ & 46.5 seconds \pm 21.03 seconds & 41.11 seconds \pm 9.48 seconds & 36.88 seconds \pm 5.28 seconds \\
\hline Adverse events $(\mathrm{n})$ & 0 & 0 & 0 \\
\hline Return to theatre (n) & 1 & 1 & 0 \\
\hline
\end{tabular}

(n): number

SD: standard deviation

\section{A P P E N D I C E S}

\section{Appendix I. Search strategies}

\section{CENTRAL}

\#1 MeSH descriptor: [Thoracic Surgery] explode all trees

\#2 MeSH descriptor: [Cardiovascular Surgical Procedures] explode all trees

\#3 MeSH descriptor: [Cardiopulmonary Bypass] explode all trees

\#4 MeSH descriptor: [Thoracic Surgical Procedures] explode all trees

\#5 MeSH descriptor: [Heart Bypass, Left] explode all trees

\#6 ((thoracic or cardiovascular or coronary or myocardial or pericardial or vascular or aorta or aorto* or valve or "ventricular reconstructive" or "off pump" or bypass) near/3 (surg* or operat*))

\#7 ("heart failure surgery" or "hypertrophic cardiomyopathy surgery")

\#8 (heart or aortocoronary or coronary or cardiopulmonary) near (bypass or "by pass") or CABG

\#9 ((valve* or arter*) near (implant* or graft* or replac* or correct*))

\#10 “myocardial revasculari*” or cavopulmonary

\#11 angioplast* or (coronary near balloon*) or cardiomyoplast*

\#12 ("mitral valve replacement*" or "aortic valve repair*” or "mitral valve repair*”)

\#13 ("maze surgery" or "arrhythmia surgery")

\#14 (“carotid endarterectom*” or "heart transplant")

\#15 (ventricular near (surg* or restor* or reconstruct*))

\#16 ((heart or cardiac or aortic) near (surg* or operat*))

\#17 MeSH descriptor: [Cardiovascular Diseases] explode all trees with qualifier(s): [Surgery - SU]

\#18 MeSH descriptor: [Aorta, Thoracic] explode all trees with qualifier(s): [Surgery - SU]

$\# 19 \# 1$ or \#2 or \#3 or \#4 or \#5 or \#6 or \#7 or \#8 or \#9 or \#10 or \#11 or \#12 or \#13 or \#14 or \#15 or \#16 or \#17 or \#18

\#20 MeSH descriptor: [Blood Transfusion] explode all trees

\#21 MeSH descriptor: [Hemorrhage] explode all trees

\#22 transfus* or bleed* or hemorrhag* or haemorrhag*

\#23 (blood near/3 loss*) or bloodloss*

$\# 24$ \#20 or \#21 or \#22 or \#23

\#25 MeSH descriptor: [Plasma] this term only

\#26 plasma:ti

Fresh frozen plasma for cardiovascular surgery (Review)

Copyright $\odot 2015$ The Cochrane Collaboration. Published by John Wiley \& Sons, Ltd. 
\#27 ((pasteurized near/2 plasma) or (pasteurised near/2 plasma) or (methylene near/2 plasma) or (solvent near/2 plasma) or (detergent near/2 plasma) or (cryoprecipitate near/2 plasma) or (supernatant near/2 plasma) or (cryosupernatant near $/ 2 \mathrm{plasma})): \mathrm{ab}$

\#28 \#25 or \#26 or \#27

\#29 \#24 and \#28

\#30 SDFFP or MBFFP or uniplas* or octaplas* or FFP or FP24 or frischplasma or "clinical plasma"

\#31 (plasma near/3 (fresh* or frozen or freeze* or prefrozen or prefreez* or thaw* or prethaw* or transfus* or infus* or treatment* ${ }^{*}$ or therap* or administ* or donor* or donat* or autologous))

\#32 ((pasteurized or pasteurised or methylene or solvent or detergent or cryoprecipitate or supernatant or cryosupernatant) and plasma): ti

\#33 (plasma near/3 "pathogen inactivated") or (plasma near/3 "pathogen reduced")

\#34 \#29 or \#30 or \#31 or \#32 or \#33

\#35 \#19 and \#34

\section{MEDLINE (OvidSP)}

1. exp Blood Transfusion/

2. exp Hemorrhage/

3. (transfus* or bleed* or hemorrhag* or haemorrhag*).tw.

4. ((blood adj3 loss $\left.{ }^{*}\right)$ or bloodloss $\left.{ }^{*}\right)$.tw.

5. or/1-4

6. Plasma/

7. plasma.ti.

8. ((pasteurized or pasteurised or methylene or solvent or detergent or cryoprecipitate or supernatant or cryosupernatant or thawed) adj2 plasma).ab.

9. or/6-8

10. 5 and 9

11. (SDFFP or MBFFP or uniplas* or octaplas* or FFP or FP24 or frischplasma or clinical plasma).ti,ab.

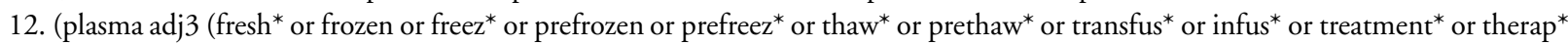
or administ* or donor* or donat* or autologous)).tw.

13. ((pasteurized or pasteurised or methylene or solvent or detergent or cryoprecipitate or supernatant or cryosupernatant) and plasma).ti.

14. (plasma adj3 (pathogen inactivated or pathogen reduced)).tw.

15. or/10-14

16. Thoracic Surgery/

17. exp Cardiovascular Surgical Procedures/

18. exp Thoracic Surgical Procedures/

19. Cardiopulmonary Bypass/ or Heart Bypass Left/

20. ((thoracic or cardiovascular or coronary or myocardial or pericardial or vascular or aorta or aorto* or valve or ventricular reconstructive or off pump or bypass) adj3 (surg* or operat*)).tw.

21. ((heart or cardiac or aortic) adj5 (surg* or operat*)).tw.

22. ((heart or aortocoronary or coronary or cardiopulmonary) adj5 (bypass or by pass)).tw.

23. ((valve* or arter*) $^{*}$ adj5 (implant* or graft* or replac* ${ }^{*}$ or correct*)).tw.

24. (myocardial revasculari* or cavopulmonary or CABG).tw.

25. (angioplast* or (coronary adj3 balloon*) or cardiomyoplast*).tw.

26. (mitral valve replacement* or aortic valve repair* or mitral valve repair*).tw.

27. (maze surgery or arrhythmia surgery).tw.

28. (carotid endarterectom* or heart transplant*).tw.

29. (ventricular adj5 (surg* or restor* or reconstruct*)).tw.

30. (heart failure surgery or hypertrophic cardiomyopathy surgery).tw.

31. Aorta Thoracic/su

32. exp Cardiovascular Diseases/su

33. or/ $16-32$

34.15 and 33

35. randomized controlled trial.pt.

Fresh frozen plasma for cardiovascular surgery (Review)

Copyright $\odot 2015$ The Cochrane Collaboration. Published by John Wiley \& Sons, Ltd. 
36. controlled clinical trial.pt.

37. randomi*.tw.

38. placebo.ab.

39. clinical trials as topic.sh.

40. randomly.ab.

41. groups.ab.

42. trial.tw.

43. or $/ 35-42$

44. exp animals/ not humans/

45.43 not 44

46. 34 and 43

\section{EMBASE (OvidSP)}

1. $\exp$ BLOOD TRANSFUSION/

2. $\exp$ BLEEDING/

3. (transfus* or bleed* or hemorrhag* or haemorrhag*).tw.

4. ((blood adj3 loss*) or bloodloss*).tw.

5. or/ $1-4$

6. exp Plasma/

7. plasma.ti.

8. ((pasteurized or pasteurised or methylene or solvent or detergent or cryoprecipitate or supernatant or cryosupernatant or thawed) adj2 plasma).ab.

9. or/6-8

10. 5 and 9

11. Fresh Frozen Plasma/

12. Plasma Transfusion/

13. (plasma adj3 (fresh* or frozen or freez* or prefrozen or prefreez* or thaw* or prethaw* ${ }^{*}$ or transfus* or infus $^{*}$ or treatment* $^{*}$ or therap* or administ* or donor* or donat* or autologous)).tw.

14. (SDFFP or MBFFP or uniplas* or octaplas* or FFP or FP24 or frischplasma or clinical plasma).tw.

15. ((pasteurized or pasteurised or methylene or solvent or detergent or cryoprecipitate or supernatant or cryosupernatant) and plasma).ti.

16. (plasma adj3 (pathogen inactivated or pathogen reduced)).tw.

17. or/ $10-16$

18. exp Thorax Surgery/

19. exp Cardiovascular Surgery/

20. Cardiopulmonary Bypass/

21. ((thoracic or cardiovascular or coronary or myocardial or pericardial or vascular or aorta or aorto* or valve or ventricular reconstructive or off pump or bypass) adj3 (surg* or operat*)).tw.

22. ((heart or cardiac or aortic) adj5 (surg* or operat*)).tw.

23. ((heart or aortocoronary or coronary or cardiopulmonary) adj5 (bypass or by pass)).tw.

24. ((valve* or arter*) adj5 (implant* or graft* or replac* or correct*)).tw.

25. (myocardial revasculari* or cavopulmonary or CABG).tw.

26. (angioplast $\$$ or (coronary adj3 balloon\$) or cardiomyoplast $\$$ ).tw.

27. (mitral valve replacement* or aortic valve repair* or mitral valve repair*).tw.

28. (maze surgery or arrhythmia surgery).tw.

29. (carotid endarterectom* or heart transplant*.tw.

30. (ventricular adj5 (surg* or restor* or reconstruct*)).tw.

31. (heart failure surgery or hypertrophic cardiomyopathy surgery).tw.

32. Thoracic Aorta/su

33. exp Cardiovascular Disease/su

34. or/18-33

35.17 and 34

36. Randomized Controlled Trial/

Fresh frozen plasma for cardiovascular surgery (Review)

Copyright $\odot 2015$ The Cochrane Collaboration. Published by John Wiley \& Sons, Ltd. 
37. Randomization/

38. Single Blind Procedure/

39. Double Blind Procedure/

40. Crossover Procedure/

41. Placebo/

42. exp Clinical Trial/

43. Prospective Study/

44. (randomi* or double-blind* or single-blind* or RCT*).tw.

45. (random* adj2 (allocat* or assign* or divid* or receiv*)).tw.

46. (crossover* ${ }^{*}$ or cross over* or cross-over* or placebo*).tw.

47. ((treble or triple) adj blind*).tw.

48. or/36-47

49. Case Study/

50. case report*.tw.

51. (note or editorial).pt.

52. or/49-51

53. 48 not 52

54. limit 53 to embase

55.35 and 54

\section{PubMed (epublications only)}

\#1 (plasma[TI] AND (fresh*[TI] OR frozen[TI] OR freez*[TI] OR prefrozen[TI] OR prefreez*[TI] OR thaw*[TI] OR prethaw*[TI] OR transfus*[TI] OR infus*[TI] OR treatment*[TI] OR therapy[TI] OR therapeutic*[TI] OR administ*[TI] OR donor*[TI] OR donat*[TI] OR autologous[TI] OR pasteurized[TI] OR pasteurised[TI] OR methylene[TI] OR solvent[TI] OR detergent[TI] OR cryoprecipitate[TI] OR supernatant[TI] OR cryosupernatant[TI]))

\#2 (SDFFP[TI] OR MBFFP[TI] OR uniplas*[TI] OR octaplas*[TI] OR FFP[TI] OR FP24[TI] OR frischplasma[TI] OR clinical plasma[TI] OR pathogen reduced plasma[TI] OR pathogen inactivated plasma[TI])

\#3 \#1 OR \#2

\#4 (cardiac OR heart OR thoracic OR cardiovascular OR angioplasty* OR coronary OR myocardial OR pericardial OR vascular OR aorta OR aortic OR aorto* OR valve OR ventricular OR off pump OR bypass)

\#5 (random* OR blind* OR "control group" OR placebo* OR controlled OR groups OR trial* OR "systematic review" OR "metaanalysis" OR metaanalysis OR "literature search" OR medline OR cochrane OR embase) AND (publisher[sb] OR inprocess[sb] OR pubmednotmedline[sb])

\#6 \#3 AND \#4 AND \#5

\section{Transfusion Evidence Library}

Clinical Specialty: Cardiovascular Surgery AND Subject Area: Plasma/FFP

\section{CINAHL (NHS Evidence)}

1. exp Blood Transfusion/

2. exp Hemorrhage/

3. (transfus* or bleed* or hemorrhag* or haemorrhag*).ti,ab

4. ((blood adj3 loss*) or bloodloss*).ti,ab

5. or/1-4

6. Plasma/

7. plasma.ti

8. ((pasteurized or pasteurised or methylene or solvent or detergent or cryoprecipitate or supernatant or cryosupernatant or thawed) adj2 plasma).ab

9. or/6-8

10.5 and 9

Fresh frozen plasma for cardiovascular surgery (Review)

Copyright $\odot 2015$ The Cochrane Collaboration. Published by John Wiley \& Sons, Ltd. 
11. (SDFFP or MBFFP or uniplas* or octaplas* or FFP or FP24 or frischplasma or clinical plasma).ti,ab

12. (plasma adj3 (fresh* or frozen or freez* or prefrozen or prefreez* or thaw* or prethaw* or transfus* or infus* or treatment* or therap* or administ* or donor* or donat* or autologous)).ti,ab

13. ((pasteurized or pasteurised or methylene or solvent or detergent or cryoprecipitate or supernatant or cryosupernatant) and plasma).ti

14. (plasma adj3 (pathogen inactivated or pathogen reduced)).ti,ab

15. or/10-14

16. Thoracic Surgery/

17. exp Cardiovascular Surgical Procedures/

18. exp Thoracic Surgical Procedures/

19. Cardiopulmonary Bypass/ or Heart Bypass Left/

20. ((thoracic or cardiovascular or coronary or myocardial or pericardial or vascular or aorta or aorto* or valve or ventricular reconstructive or off pump or bypass) adj3 (surg* or operat*)).ti,ab

21. ((heart or cardiac or aortic) adj5 (surg* or operat*)).ti,ab

22. ((heart or aortocoronary or coronary or cardiopulmonary) adj5 (bypass or by pass)).ti,ab

23. ((valve* or arter*) adj5 (implant* or graft* or replac* or correct*)).ti,ab

24. (myocardial revascular* or cavopulmonary or CABG).ti,ab

25. (angioplast* or (coronary adj3 balloon*) or cardiomyoplast*).ti,ab

26. (mitral valve replacement* or aortic valve repair* or mitral valve repair*).ti,ab

27. (maze surgery or arrhythmia surgery).ti,ab

28. (carotid endarterectom* or heart transplant*).ti,ab

29. (ventricular adj5 (surg* or restor* $^{*}$ or reconstruct*)).ti,ab.

30. (heart failure surgery or hypertrophic cardiomyopathy surgery).ti,ab

31. Aorta Thoracic/su

32. exp Cardiovascular Diseases/su

33. or/16-32

34.15 and 33

35. exp Clinical Trials/

36. Clinical Trial.pt.

37. (controlled trial* or clinical trial*).ti,ab

38. (singl* blind* or doubl* blind* or trebl* blind* or tripl* blind* or singl* mask* or doubl* mask* or trebl* mask* or tripl* mask*).ti,ab

39. randomi*.ti,ab

40. Random Assignment/

41. (random* adj2 (assign* or allocat*)).ti,ab

42. (phase three or phase III or phase three).ti,ab

43. Placebos/

44. Quantitative Studies/

45. or/35-44

46. 34 and 45

\section{LILACS}

tw:((ti:(plasma OR FFP)) AND (tw:(cardiac OR heart OR thoracic OR cardiovascular OR coronary OR thoracic OR angioplasty OR myocardial OR pericardial OR vascular OR aorta OR aortic OR ventricular OR bypass))) AND (instance:“regional”) AND ( db: (“LILACS”) AND type " of study:(“clinical trials”))

\section{IndMed}

(plasma OR FFP) AND (cardiac OR heart OR thoracic OR cardiovascular OR coronary OR thoracic OR cardiovascular OR angioplasty OR myocardial OR pericardial OR vascular OR aorta OR aortic OR ventricular OR bypass) AND (randomized OR randomised OR randomly OR blind OR blinded OR trial OR allocated OR allocated OR assigned OR control group OR controlled study OR intervention))

Fresh frozen plasma for cardiovascular surgery (Review)

Copyright () 2015 The Cochrane Collaboration. Published by John Wiley \& Sons, Ltd. 


\section{KoreaMed}

"Randomized Controlled Trial" [PT] AND plasma [ALL] AND transfusion [ALL] OR

"Randomized Controlled Trial" [PT] AND plasma [TI] OR

"Randomized Controlled Trial" [PT] AND FFP [ALL]

\section{PakMediNet}

(trial OR randomized OR randomised) AND (plasma OR FFP OR transfusion)

\section{Web of Science: Conference Proceedings Citation Index - Science (CPCI-S), 1990 to present}

TOPIC: (FFP OR (plasma NEAR/3 (fresh* or frozen or freez* or prefrozen or prefreez* or thaw* or prethaw* or transfus* or infus* or therapy or therapeutic or administ* or donor* or donat* or autologous or pasteurized or pasteurised or methylene or solvent or detergent or cryoprecipitate or supernatant or cryosupernatant))) AND TOPIC: ((cardiac OR heart OR thoracic OR cardiovascular OR coronary OR cardiovascular OR angioplasty OR myocardial OR pericardial OR vascular OR aorta OR aortic OR ventricular OR "off pump" OR bypass)) AND TOPIC: ((randomi* OR randomly OR blind* OR trial OR allocat* OR assign* OR "control group" OR “controlled study" OR intervention))

\section{WHO ICTRP search portal}

Title: fresh plasma OR frozen plasma OR plasma transfusion OR plasma infusion OR thawed plasma OR donor plasma OR donated plasma OR autologous plasma OR FFP

Condition: cardiac OR heart OR thoracic OR cardiovascular OR coronary OR angioplasty OR myocardial OR pericardial OR vascular OR aorta OR aortic OR ventricular OR bypass

OR

Title: fresh plasma OR frozen plasma OR plasma transfusion OR plasma infusion OR thawed plasma OR donor plasma OR donated plasma

Intervention: cardiac OR heart OR thoracic OR cardiovascular OR coronary OR angioplasty OR myocardial OR pericardial OR vascular $\mathrm{OR}$ aorta $\mathrm{OR}$ aortic $\mathrm{OR}$ ventricular $\mathrm{OR}$ bypass

\section{ClinicalTrials.gov}

Search Terms: "fresh plasma” OR "frozen plasma” OR "plasma transfusion" OR "plasma infusion" OR "thawed plasma” OR "donor plasma” OR "donated plasma” OR "autologous plasma” OR FFP

Study Type: Interventional Studies

Conditions/Interventions: cardiac OR heart OR thoracic OR cardiovascular OR coronary OR angioplasty OR myocardial OR pericardial OR vascular OR aorta OR aortic OR ventricular OR bypass

\section{ISRCTN Register and PakMediNet}

"fresh plasma” OR "frozen plasma” OR "plasma transfusion” OR “plasma infusion” OR "thawed plasma” OR "donor plasma” OR "donated plasma” OR "autologous plasma” OR FFP

\section{EUDRACT}

("fresh plasma” OR "frozen plasma” OR "plasma transfusion" OR "plasma infusion" OR "thawed plasma” OR "donor plasma” OR "donated plasma” OR "autologous plasma” OR FFP) AND (cardiac OR heart OR thoracic OR cardiovascular OR coronary OR angioplasty OR myocardial OR pericardial OR vascular OR aorta OR aortic OR ventricular OR bypass) 


\section{CONTRIBUTIONS OFAUTHORS}

MD and SS were (transfusion) content experts for the review.

RS was a (cardiac surgery) content expert for the review.

MD and RS undertook the screening and selection of trials, data extraction, assessment of risk of bias and analysis of results, and led the preparation of the final report.

SB was the methodological expert for this review and initially project managed the review, provided support and training to MD and RS, and provided support with data analysis and the preparation of the final report.

$\mathrm{CD}$ was the information specialist who developed and implemented the search strategies and undertook the first sift of identified references.

MT was the statistical advisor for the review.

MT and SS contributed to the data analysis.

SB, MT and SS helped to prepare the final report.

AM and IA were content experts for the protocol stage of the review, contributed to the development of the protocol, commented on the final version of the review and developed the 'Summary of findings' table.

\section{DECLARATIONSOF INTEREST}

MD: None known.

RS: None known.

SB: None known.

CD: None known.

MT: My role as a statistical editor/referee for 4 Cochrane groups (Anaesthesia, Wounds, Breast Cancer, and Sexually Transmitted Infections), and previous editorial work with the Injuries Group, are independent to my involvement in this review. I declare that my involvement here as an author has no related financial relationships.

AM: None known.

IA: None known.

SS: None known.

\section{SOURCES OF SUPPORT}

\section{Internal sources}

- National Blood Service, Research and Development, UK. 


\section{External sources}

- Department of International Development (DFID), UK.

\section{DIFFERENCES BETWEEN PROTOCOLANDREVIEW}

Plasmapheresis and plasma exchange are specialised techniques in which patient plasma is removed and fractionated in an apheresis machine, and replaced by other solutions. These replacement solutions may include (allogeneic) FFP (or other agent such as human albumin solution), and are then re-infused into the patient. The principle aim of this therapy is the removal of a component in blood from the patient, rather than the transfusion of FFP as a source of supplementary pro-coagulant factor. Consequently, we excluded studies of plasmapheresis and plasma exchange from this review.

The protocol (types of interventions) differentiates between FFP compared with no FFP, and FFP compared with an active comparator, be that clinical plasma (any type) or a plasma-derived blood product (for example, prothrombin complex concentrate). We discussed separating the analysis of data in this way both before and after data were extracted from the included studies, but decided on both occasions that there was no clinical justification for this separation at the data analysis stage. As a result the data have been analysed and presented as FFP versus any comparator. We have assessed the statistical heterogeneity of the data that were pooled in a meta-analysis and looked into this further when the $\mathrm{I}^{2}$ value was greater than $50 \%$ (as pre-specified in the protocol).

We used a PRISMA flow chart in this review in preference to a QUORUM flow chart, as PRISMA flow charts have largely replaced QUORUM flow charts (Boccia 2009).

In the protocol we made plans to assume a worst-case scenario analysis of the main outcome (in hospital or 30-day mortality) if patients were lost to follow-up. Such an analysis would assume that those patients who were lost to follow-up in the treatment group had the worse outcome while patients lost to follow-up in the control group had the best outcome. Given the low mortality rate in the studies that reported this outcome, we removed this analysis, as it was felt to be misleading.

\section{Methods for future updates}

For future updates of this review, we will analyse separately trials including or excluding patients receiving preoperative medications with major effects on the coagulation system (e.g. anticoagulant, antiplatelet agents). There were insufficient data found in this review, but if data are sufficient in future updates of this review, we will undertake meta-regression.

There were not sufficient data for subgroup analysis in this review but we will assess the following subgroups in future updates of this review if there are sufficient data:

- type of surgical procedure;

- type of plasma component used; and

- dose of plasma component used.

For future reviews we will explore the robustness of the overall results to variation in the following factors if there are sufficient data:

- study quality;

- nature of the intervention/comparator;

- types of participants with reference to the complexity of surgery/intervention (whether major or minor).

The first is a commonly applied approach in Cochrane reviews, responding to concerns about the exaggeration of treatment effects in studies with poorly conducted randomisation. The second recognises the intrinsic complexity of all interventions in transfusion medicine.

Fresh frozen plasma for cardiovascular surgery (Review) 